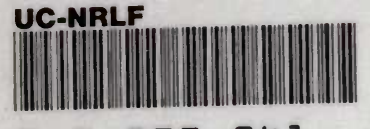
B 3379041

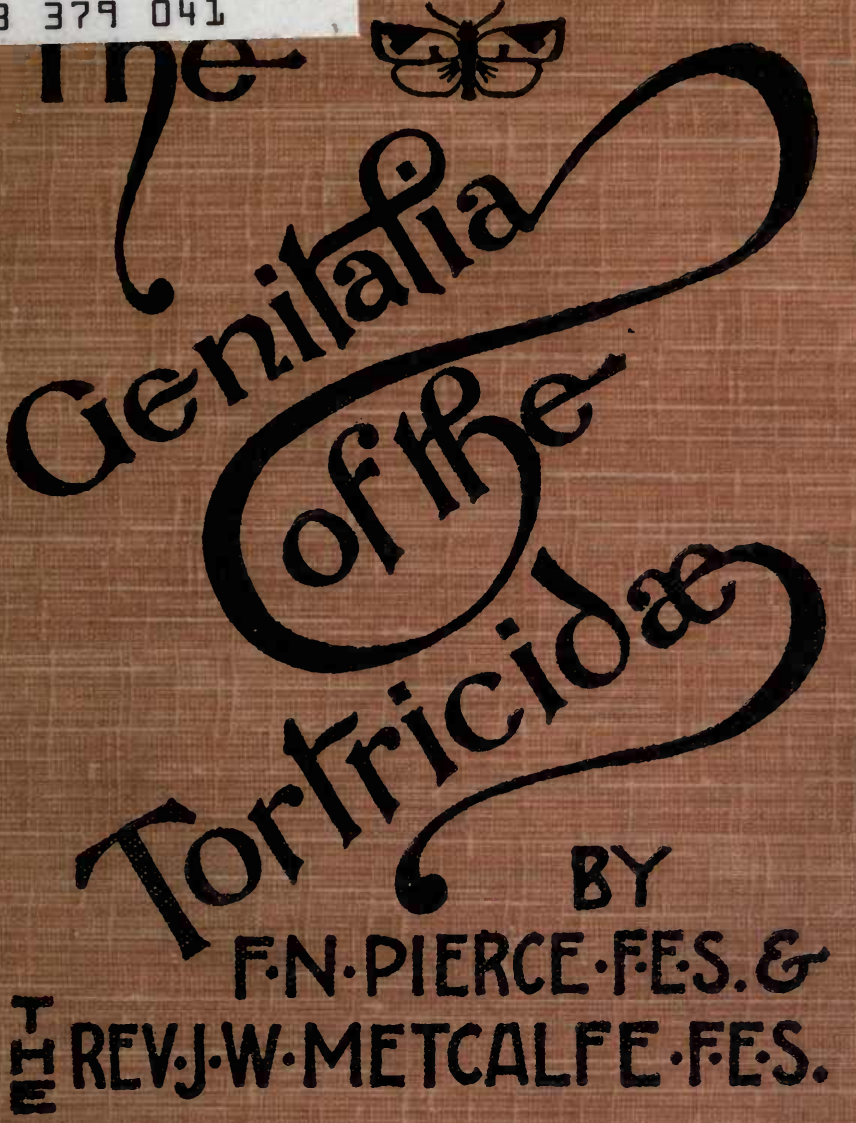




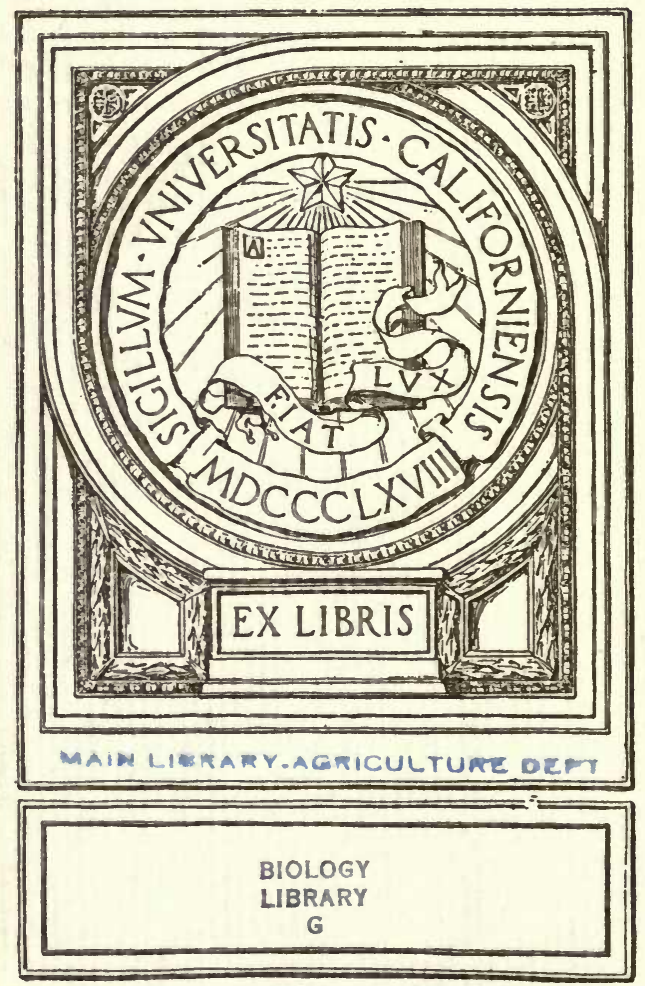




$$
\text { Esw57? }
$$



THE GENITALIA OF THE BRITISH TORTRICIDÆ. 

To do the wrong thing is better than doing nothing at all. 



\section{The Genitalia}

of

\section{The Group Tortricidæ}

of the Lepidoptera

of the

\section{British Islands.}

AN ACCOUNT OF THE MORPHOLOGY OF THE MALE CLASPING ORGANS AND THE CORRESPONDING ORGANS OF THE FEMALE.

BY

F. N. PIERCE, F.E.S.

AND

The Rev. J. W. METCALFE, M.A., F.E.S.

ILLUSTRATED BY THE REV. J. W. METCALFE, FROM PREPARATIONS MADE BY F. N. PIERCE.

OUNDLE, NORTHANTS:

F. N. Pierce, The Old Rectory, Warmington. 
Printed by The Northern Publishing Co., Ltd., 17 Goree Piazzas, Liverpool.

Plates by T. Chell, 22, Cable Street, Liverpool.

[COPYRIGHT UNDER ACT OF 1911.]

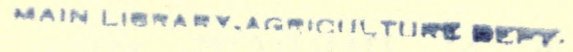


INDEX OF GENERA.

Acroclita \begin{tabular}{ccc|lllc} 
& & Page & & & \multicolumn{3}{c}{ Page } \\
$\ldots$ & $\ldots$ & 56 & Grapholita & $\ldots$ & $\ldots$ & 85 \\
$\ldots$ & $\ldots$ & 32 & Gypsonoma & $\ldots$ & $\ldots$ & 77 \\
$\ldots$ & $\ldots$ & 21 & Hemimene & $\ldots$ & $\ldots$ & 93
\end{tabular}

Æthes

Agapeta

Aleimma

Amelia

Anchylopera

Ancylis

Apotomis

Archips

Argyrotaenia

Argrotoxa

Argyroploce

Astatia

Bactra

Capua

Catopria

Celypa ...

Cerata

Chrosis

Clepsis

Clysia

Cnephasia

Cochylis

Commophila

Cydia

Eclectis

Enarmonia

Endopisa

Enyphantes

Epagoge

Ephippiphora

Epiblema

Eriopsela

Eucosma

Eudemis

Eulia

Euspila

Euxanthis

Evetria

Hysterosia

Isotrias

Laspeyresia

... 15

... 55

... 53

Lipoptycha

... 40

... 1

... 1

... 16

... 45

... 58

... 40

... 7

... 73

Lobesia ...

Lozotaenia

Nephodesme

Neurasthenia

Notocelia

Olethreutes

Olindia

Oxigrapha

Pammene

... 50

... 87

... 24

... 5

... 26

Pandemis

Panoplia

Pardia

Peronea

92

.. 96

.. 39

... 6

.. 12

... 65

... 66

... 43

... 15

... 24

... 88

.. 26 Phalonia

.. 10 Pharmacis

... 36 Phaneta

... 30

... 81

... 18

... 53

... 86

... 14

$\begin{array}{ll}\ldots & 7 \\ \ldots & \end{array}$

... 85

... 68

... 67

... 72

... 44

Phiaris ...

Philedone

Ptycholoma

Phtheochroa

Proteopteryx

Rhocodia

Rhopobota

Rhyacionia

Sciaphila

Selania

... 3

... 60

... 67

... 20

.. 29

... 30

... 70

... 48

... 6

... 7

... 30

... 62

... 23

... 74

... 79

... 15

... 93

$\begin{array}{llll}\text { Sparganothis } & \ldots & \ldots & 25\end{array}$

$\begin{array}{llll}\text { Spilonata } & \ldots & \ldots & 76\end{array}$

\begin{tabular}{ll|llll}
$\ldots$ & 9 & Strophedra & $\ldots$ & $\ldots$ & 83
\end{tabular}

$\begin{array}{llllll}\ldots & 84 & \text { Tortricodes } & \ldots & \ldots & 14\end{array}$

$\begin{array}{llllll}\ldots & 30 & \text { Tortrix } & \ldots & \ldots & 19\end{array}$

\begin{tabular}{ll|llll}
$\ldots$ & 63 & Zeiraphera & $\ldots$ & $\ldots$ & 56
\end{tabular} 
viii.

\section{INDEX OF SPECIES.}

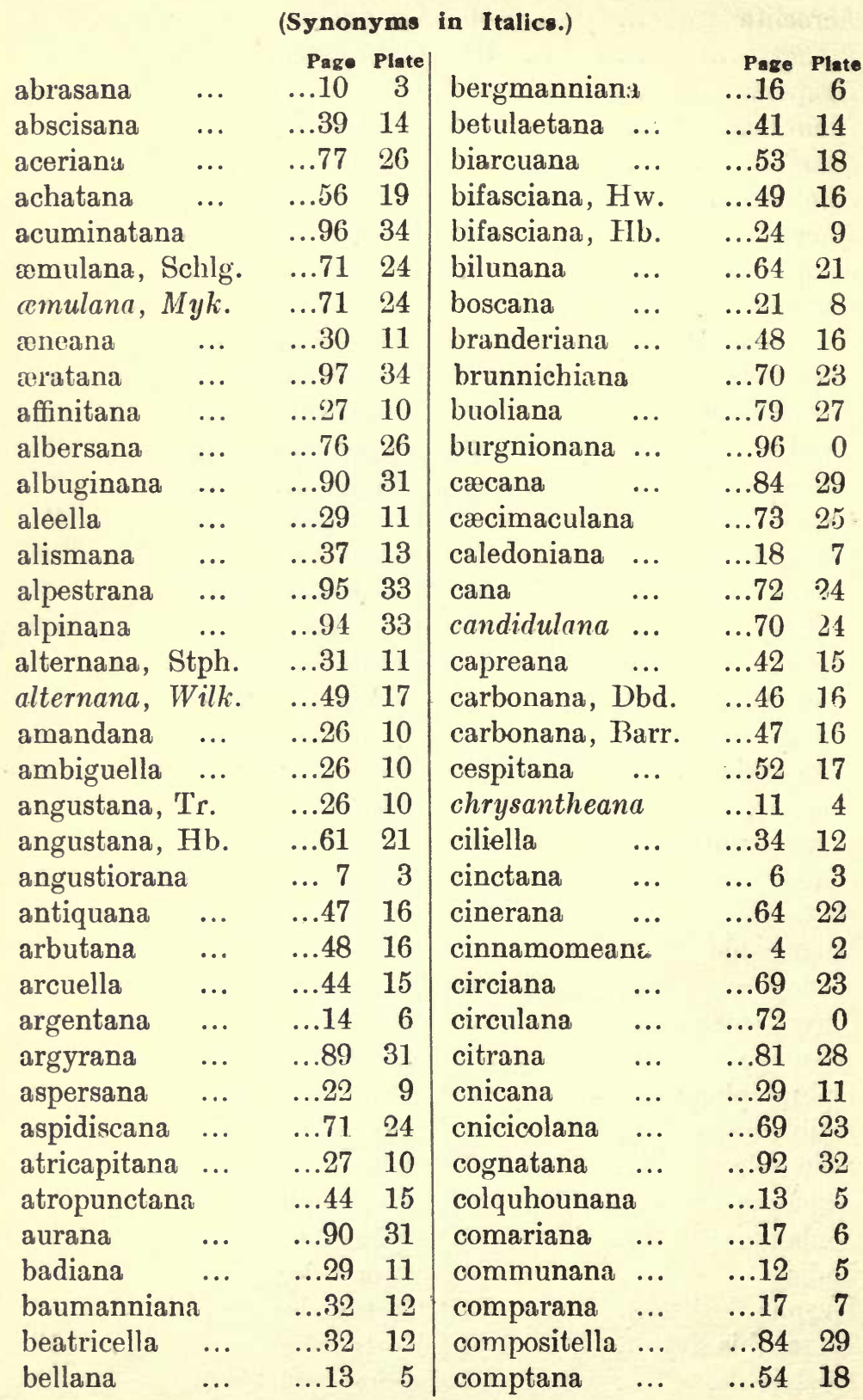


INDEX OF SPECIES-(Synonyms in Italics).

\begin{tabular}{|c|c|c|c|c|c|c|c|}
\hline & & $\begin{array}{r}\text { Page } \\
\ldots 14\end{array}$ & $\begin{array}{c}\text { Plate } \\
6\end{array}$ & favillaceana & & $\begin{array}{r}\text { Page } \\
\ldots \quad 7\end{array}$ & \\
\hline & & $\ldots 82$ & 28 & ferrugana & $\ldots$ & $\ldots .21$ & \\
\hline$n a, 1$ & $H .-S$. & $\ldots .56$ & 19 & & ... & ...89 & \\
\hline & $\ldots$ & $\ldots 95$ & 33 & & $\ldots$ & $\ldots 23$ & \\
\hline sana. & $\ldots$ & $\ldots 11$ & 4 & flaviciliana & ... & $\ldots 36$ & 13 \\
\hline $\operatorname{inanâ}$ & & $\ldots 71$ & 24 & flavidorsana & & $\ldots 94$ & 33 \\
\hline & $\ldots$ & $\ldots 16$ & 6 & flexana & ... & $\ldots 83$ & 29 \\
\hline & $\ldots$ & ...93 & 32 & & $\ldots$ & $\ldots 70$ & 23 \\
\hline $\mathrm{a}, \mathrm{Hb}$ & & $\ldots 41$ & 14 & forskaleana & $\ldots$ & $\ldots 20$ & \\
\hline $\mathrm{a}, \mathrm{Hb}$ & & $\ldots 57$ & 19 & forsterana . & $\ldots$ & .. 6 & 2 \\
\hline & & $\ldots 3$ & 1 & fracifasciana & & $\ldots 75$ & 26 \\
\hline ohoran & & $\ldots 93$ & 32 & francillonana & & $\ldots 32$ & 12 \\
\hline & $\ldots$ & $\ldots 5$ & 2 & fuligana, $\mathrm{Hb}$. & & $\ldots 47$ & 16 \\
\hline netana & & $\ldots 89$ & 31 & fuligana, Brt. & & $\ldots 46$ & 16 \\
\hline & $\ldots$ & ... 2 & 1 & fuligana, Hw & & ...39 & 14 \\
\hline & $\ldots$ & $\ldots 62$ & 21 & fulvana & $\ldots$ & $\ldots 72$ & 24 \\
\hline & $\ldots$ & $\ldots 20$ & 8 & & $\ldots$ & $\ldots 86$ & 30 \\
\hline & $\ldots$ & $\ldots 62$ & 21 & & $\ldots$ & $\ldots 40$ & 14 \\
\hline igana & & $\ldots 28$ & 10 & & & $\ldots 88$ & 30 \\
\hline & $\ldots$ & $\ldots 49$ & 17 & ana & $\ldots$ & $\ldots 90$ & 31 \\
\hline & $\ldots$ & $\ldots 78$ & 26 & & $\ldots$ & $\ldots 75$ & \\
\hline & $\ldots$ & ... 2 & 1 & rana & & $\ldots 88$ & 30 \\
\hline & $\ldots$ & $\ldots 34$ & 12 & & $\ldots$ & $\ldots 12$ & \\
\hline ana & & $\ldots 64$ & 21 & & $\ldots$ & $\ldots 46$ & 16 \\
\hline & ... & $\ldots .54$ & 18 & & $\ldots$ & $\ldots .92$ & 32 \\
\hline & $\ldots$ & $\ldots 33$ & 12 & & $\ldots$ & $\ldots 6$ & 2 \\
\hline & $\ldots$ & $\ldots 44$ & 15 & & & $\ldots 38$ & 13 \\
\hline & $\ldots$ & $\ldots 54$ & 18 & & $\ldots$ & $\ldots 28$ & 11 \\
\hline & $\ldots$ & $\ldots 57$ & 19 & & $\ldots$ & $\ldots 69$ & 23 \\
\hline & $\ldots$ & $\ldots 29$ & 11 & & $\ldots$ & $\ldots 42$ & 15 \\
\hline & $\ldots$ & $\ldots 63$ & 21 & & $\ldots$ & ...92 & 32 \\
\hline & ... & ... 3 & 1 & & $\ldots$ & $\ldots 7$ & \\
\hline & $\ldots$ & $\ldots 86$ & 29 & har & $\ldots$ & $\ldots 30$ & 11 \\
\hline dayana & & $\ldots 51$ & 17 & inniana & & $\ldots 41$ & 14 \\
\hline & $\ldots$ & $\ldots 36$ & 13 & has & & $\ldots 18$ & \\
\hline & ... & $\ldots 33$ & 12 & & $\ldots$ & $\ldots 4$ & \\
\hline & $\ldots$ & ... 4 & 2 & & $\cdots$ & $\ldots 95$ & 33 \\
\hline & ... & $\ldots 81$ & 0 & & .. & $\ldots 22$ & \\
\hline & ... & $\ldots 23$ & 9 & & ... & $\ldots 37$ & 13 \\
\hline & $\ldots$ & $\ldots 47$ & 16 & ricana & .. & ...93 & 32 \\
\hline Aortand & & $\ldots 39$ & 14 & & $\therefore$ & $\ldots 86$ & 30 \\
\hline pallidana. & $\ldots$ & $\ldots 72$ & 25 & immundana & $\ldots$ & $\ldots 61$ & 21 \\
\hline
\end{tabular}


INDEX OF SPECIES-(Synonyms in Italics).

\begin{tabular}{|c|c|c|c|c|c|c|c|}
\hline implicitana & $\ldots$ & $\begin{array}{c}\text { Page } \\
\ldots .34\end{array}$ & $\begin{array}{c}\text { Plate } \\
12\end{array}$ & mitterbacher & iana & $\begin{array}{c}\text { Paze } \\
\ldots .53\end{array}$ & $\begin{array}{l}\text { Plate } \\
18\end{array}$ \\
\hline & ... & $\ldots 13$ & 5 & mixtana & $\ldots$ & $\ldots .21$ & 8 \\
\hline natana & $\ldots$ & $\ldots 67$ & 22 & musculana & $\ldots$ & ... 3 & 1 \\
\hline certana & $\ldots$ & $\ldots 10$ & 3 & mussehliana & & $\ldots 38$ & 13 \\
\hline piana & $\ldots$ & $\ldots 25$ & 10 & mygindana & $\ldots$ & $\ldots 48$ & 16 \\
\hline rnatana & $\ldots$ & $\ldots .54$ & 18 & myrtillana & $\ldots$ & $\ldots 55$ & 19 \\
\hline ernana & $\ldots$ & $\ldots 85$ & 29 & nævana & $\ldots$ & $\ldots 75$ & 26 \\
\hline guana & ... & $\ldots 49$ & 17 & nana... & ... & $\ldots 28$ & 10 \\
\hline liana & $\ldots$ & $\ldots 91$ & 31 & nanana & $\ldots$ & $\ldots 65$ & 22 \\
\hline cunana & $\ldots$ & $\ldots 50$ & 17 & neglectanà & ... & $\ldots 78$ & 27 \\
\hline ætana & $\ldots$ & $\ldots 55$ & 19 & nemorivaga & $\ldots$ & $\ldots 61$ & 20 \\
\hline fauryana & $\ldots$ & $\ldots 4$ & 2 & nigricana, $\mathrm{H}$ & S. & $\ldots 63$ & 21 \\
\hline nceolana & $\ldots$ & $\ldots 40$ & 14 & nigricana, St & tph. & $\ldots 87$ & 30 \\
\hline riciana & $\ldots$ & $\ldots 77$ & 0 & nigricostana & & $\ldots 47$ & 0 \\
\hline tiorana & $\ldots$ & $\ldots 71$ & 24 & nigromacular & & $\ldots 70$ & 24 \\
\hline tifasciana & $\ldots$ & $\ldots 51$ & 17 & nimbana & $\ldots$ & $\ldots 91$ & 31 \\
\hline ana & $\ldots$ & $\ldots 7$ & 3 & nisell & $\ldots$ & $\ldots 65$ & 22 \\
\hline ainana & $\ldots$ & $\ldots 87$ & 30 & nitid & $\ldots$ & $\ldots 83$ & 29 \\
\hline striana & $\ldots$ & $\ldots 93$ & 32 & nive & $\ldots$ & $\ldots 20$ & 8 \\
\hline siana & $\ldots$ & $\ldots 22$ & 9 & notulana & $\ldots$ & $\ldots 27$ & 10 \\
\hline & $\ldots$ & $\ldots 24$ & 3 & nubilana & $\ldots$ & $\ldots 14$ & 6 \\
\hline lana & .. & $\ldots 69$ & 23 & oblor & ... & $\ldots 46$ & 16 \\
\hline lis & $\ldots$ & ...39 & 14 & obs & $\ldots$ & $\ldots 62$ & 0 \\
\hline lœeflingiana & $\ldots$ & ...19 & 8 & na, S & tph. & $\ldots 90$ & 31 \\
\hline logaea & $\ldots$ & $\ldots 80$ & 28 & obscurana, & Wilk. & $\ldots 90$ & 31 \\
\hline logiana & $\ldots$ & $\ldots 18$ & 7 & obtus & $\ldots$ & $\ldots .54$ & 18 \\
\hline long & $\ldots$ & $\ldots 11$ & 4 & na & & $\ldots .57$ & 19 \\
\hline iana & $\ldots$ & $\ldots 23$ & 9 & ocell & & $\ldots 76$ & 26 \\
\hline$a$ & $\ldots$ & $\ldots 55$ & 19 & ucana & & $\ldots 43$ & 15 \\
\hline lana & $\ldots$ & $\ldots 37$ & 13 & heime & riana & $\ldots 89$ & 30 \\
\hline & $\ldots$ & $\ldots 21$ & 8 & octomaculan: & & $\ldots 11$ & 4 \\
\hline aculosana & $\ldots$ & $\ldots 26$ & 10 & ophthalmicar & & $\ldots 58$ & 20 \\
\hline anniana & $\ldots$ & $\ldots 27$ & 10 & oppressana & $\ldots$ & $\ldots 78$ & 27 \\
\hline arginana & $\ldots$ & $\ldots 46$ & 16 & orobana & $\ldots$ & $\ldots 86$ & 29 \\
\hline laritima & $\ldots$ & ...70 & 24 & osseana & $\ldots$ & $\ldots 13$ & 6 \\
\hline maritimana & $\ldots$ & $\ldots 33$ & 12 & palleana & $\ldots$ & ... 8 & 3 \\
\hline mercuriana & $\ldots$ & $\ldots 61$ & 21 & pallidana & $\ldots$ & $\ldots 36$ & 13 \\
\hline etallicana & $\ldots$ & $\ldots 49$ & 17 & pallifrontella & $\ldots$ & $\ldots 84$ & 29 \\
\hline ican & $\ldots$ & $\ldots 50$ & 17 & paludana & $\ldots$ & $\ldots 55$ & 19 \\
\hline gramms & ana & $\ldots 81$ & 28 & trana & $\ldots$ & $\ldots 50$ & 17 \\
\hline & $\ldots$ & .. 9 & 3 & parvulana & $\ldots$ & $\ldots 72$ & 24 \\
\hline inutana & $\ldots$ & $\ldots 78$ & 26 & pascuana & ... & ...11 & 4 \\
\hline
\end{tabular}


$x i$.

INDEX OF SPECIES-(Synonyms in Italic8).

\begin{tabular}{|c|c|c|c|c|c|c|c|}
\hline pasivana & $\ldots$ & $\begin{array}{c}\text { Page } \\
\ldots 11\end{array}$ & $\begin{array}{c}\text { Plate } \\
4\end{array}$ & reliquana & $\cdots$ & $\begin{array}{c}\text { Page } \\
\ldots .39\end{array}$ & $\begin{array}{l}\text { Plate } \\
14\end{array}$ \\
\hline pauperana & $\ldots$ & $\ldots 70$ & 24 & resinella & .. & $\ldots 73$ & 25 \\
\hline penkleriana & ... & $\ldots 60$ & 20 & reticulata & ... & $\ldots 23$ & \\
\hline penthinana & ... & $\ldots 44$ & 15 & retiferana & .. & $\ldots 80$ & \\
\hline ana & $\ldots$ & $\ldots 13$ & 5 & rhediellì & $\ldots$ & ...90 & 31 \\
\hline pidana & $\ldots$ & $\ldots 85$ & 29 & ribeana & ... & $\ldots 4$ & \\
\hline ana, & S.D. & $\ldots 38$ & 13 & & ... & $\ldots 51$ & 17 \\
\hline & $\ldots$ & $\ldots 21$ & 8 & & ... & ...67 & $z$ \\
\hline & ... & $\ldots 17$ & 0 & olana & .. & $\ldots 67$ & 22 \\
\hline & $\ldots$ & $\ldots 94$ & 33 & & ... & ... 2 & \\
\hline pflugiana & ... & $\ldots 69$ & 23 & & $\ldots$ & $\ldots 36$ & \\
\hline & ... & ... 1 & 1 & roseticolana & $\ldots$ & $\ldots 86$ & 30 \\
\hline & $\ldots$ & $\ldots 25$ & 10 & rubiginosana & $\ldots$ & $\ldots 63$ & \\
\hline na, & Dbd. & $\ldots 80$ & 27 & rufana, Sc. & $\ldots$ & $\ldots 52$ & 18 \\
\hline & $\ldots$ & ...79 & 27 & , Schif & f. & $\ldots 22$ & \\
\hline ana & $\ldots$ & ...95 & 33 & $r u f i$ & .. & $\ldots 88$ & 30 \\
\hline & $\ldots$ & $\ldots 97$ & 34 & & ... & $\ldots 57$ & \\
\hline & $\ldots$ & ... 2 & 1 & & ... & $\ldots 30$ & 11 \\
\hline $\mathrm{a}, \mathrm{Ha}$ & aiv. & $\ldots 1$ & 1 & & $\ldots$ & $\ldots 35$ & 13 \\
\hline$a, H b$ & & $\ldots 94$ & 33 & & .. & .. 5 & \\
\hline xana & $\ldots$ & $\ldots 45$ & 15 & & $\ldots$ & $\ldots 29$ & 11 \\
\hline & $\ldots$ & $\ldots 82$ & 28 & & $\ldots$ & ...35 & 12 \\
\hline & $\ldots$ & $\ldots 91$ & 31 & sali & ... & $\ldots 43$ & 15 \\
\hline & ... & $\ldots 73$ & 25 & sar & ... & ...30 & \\
\hline ana & $\ldots$ & $\ldots 44$ & 15 & & ... & ...97 & 34 \\
\hline & $\ldots$ & $\ldots 17$ & 0 & & $\ldots$ & $\ldots 42$ & 15 \\
\hline & $\ldots$ & ... 9 & 3 & & $\ldots$ & $\ldots 21$ & \\
\hline & $\ldots$ & $\ldots 45$ & 15 & ana & $\ldots$ & $\ldots 17$ & \\
\hline & $\ldots$ & ... 8 & 3 & ian: & & $\ldots 25$ & 10 \\
\hline ana & $\ldots$ & $\ldots 63$ & 21 & & $\ldots$ & $\ldots 50$ & 17 \\
\hline & $\ldots$ & $\ldots 43$ & 15 & scol & $\ldots$ & $\ldots 85$ & 29 \\
\hline & ... & $\ldots 46$ & 16 & sco & $\ldots$ & $\ldots 72$ & 24 \\
\hline & ... & $\ldots .71$ & 24 & scut & ... & ...xxii & \\
\hline & $\ldots$ & $\ldots 83$ & 28 & sell & ... & $\ldots 46$ & 16 \\
\hline ana & $\ldots$ & $\ldots 52$ & 17 & albana & $\ldots$ & $\ldots 6$ & \\
\hline & $\ldots$ & $\ldots 66$ & 22 & sciana & & $\ldots 41$ & 14 \\
\hline & .. & $\ldots 67$ & 23 & cana & & $\ldots 59$ & 20 \\
\hline liana & $\ldots$ & $\ldots 94$ & 33 & sene & $\ldots$ & $\ldots 96$ & 3 \\
\hline urgiana & & $\ldots .57$ & 19 & sequ & $\ldots$ & $\ldots 96$ & 34 \\
\hline & & $\ldots 64$ & 21 & servillana & $\ldots$ & $\ldots 87$ & 30 \\
\hline & & $\ldots 15$ & 6 & shepherdana & ... & $\ldots 22$ & \\
\hline regiana & $\ldots$ & $\ldots 90$ & 31 & siculana & ... & $\ldots 55$ & 19 \\
\hline
\end{tabular}


xii.

INDEX OF SPECIES-(Synonyms in Italics).

\begin{tabular}{|c|c|c|c|c|c|c|c|}
\hline signatana & $\ldots$ & $\begin{array}{c}\text { Page } \\
\ldots 61\end{array}$ & $\begin{array}{c}\text { Plate } \\
20\end{array}$ & trimaculana, & Don. & $\begin{array}{c}\text { Page } \\
\ldots .58\end{array}$ & $\begin{array}{l}\text { Plate } \\
20\end{array}$ \\
\hline similana & $\ldots$ & $\ldots 60$ & 20 & trimaculana, & $H w$. & $\ldots 66$ & 22 \\
\hline mplana & $\ldots$ & $\ldots 76$ & 26 & tripoliana & ... & $\ldots 71$ & 24 \\
\hline simpliciana & $\ldots$ & $\ldots 95$ & 33 & tripunctana & $\ldots$ & $\ldots 67$ & 22 \\
\hline sinuana, $\mathrm{Hb}$ & & ...59 & 20 & turbidana & $\ldots$ & $\ldots 70$ & 23 \\
\hline smeathmann & iana & $\ldots 33$ & 12 & turionana & $\ldots$ & $\ldots 74$ & 25 \\
\hline landriana & $\ldots$ & $\ldots 59$ & 20 & udana, Gn. & $\ldots$ & $\ldots 27$ & 10 \\
\hline rbiana & $\ldots$ & ... 2 & 1 & udmanniana & $\ldots$ & $\ldots 66$ & 22 \\
\hline rdidana & $\ldots$ & $\ldots 59$ & 20 & ulicitana & $\ldots$ & $\ldots 82$ & 28 \\
\hline rorculana & $\ldots$ & $\ldots 42$ & 14 & ulmana & $\ldots$ & $\ldots 15$ & \\
\hline jiniana & $\ldots$ & $\ldots 91$ & 31 & umbrana & $\ldots$ & $\ldots 20$ & \\
\hline na & $\ldots$ & $\ldots 92$ & 32 & unce & ... & $\ldots 54$ & 18 \\
\hline splendidulan & & $\ldots 89$ & 30 & unguicella & $\ldots$ & $\ldots 54$ & 18 \\
\hline sponsana & $\ldots$ & ...18 & 7 & unifasciana & $\ldots$ & $\ldots 5$ & 2 \\
\hline staintoniana & & $\ldots 42$ & 15 & upupana & $\ldots$ & $\ldots 55$ & 19 \\
\hline straminea & $\ldots$ & $\ldots 31$ & 11 & urticana & $\ldots$ & $\ldots 49$ & 16 \\
\hline striana & $\ldots$ & $\ldots 52$ & 0 & ustomaculana & & ...74 & 26 \\
\hline robilella & $\ldots$ & $\ldots 87$ & 30 & ustulana, $H u$ & & $\ldots 46$ & 16 \\
\hline abbaumanni & iana & $\ldots 32$ & 12 & niana & & $\ldots 75$ & 26 \\
\hline bocellana & $\ldots$ & $\ldots 60$ & 20 & na, $H_{1}$ & & $\ldots 43$ & 15 \\
\hline ana & $\ldots$ & $\ldots 35$ & 13 & $\mathrm{a}, \mathrm{Sc}$ & chif. & $\ldots 23$ & 9 \\
\hline sequana, & H.-S. & $\ldots 56$ & 19 & vecti & $\ldots$ & $\ldots 38$ & 13 \\
\hline dana, & H.-S. & $\ldots 65$ & 22 & vibur & $\ldots$ & ... 8 & \\
\hline ana & $\ldots$ & $\ldots 82$ & 28 & reana & $\ldots$ & $\ldots 12$ & \\
\hline sana & $\ldots$ & $\ldots 66$ & 22 & viridana & $\ldots$ & $\ldots 19$ & 8 \\
\hline trana & $\ldots$ & $\ldots 83$ & 28 & vineana & $\cdots$ & $\ldots 51$ & 17 \\
\hline taedella & $\ldots$ & $\ldots 64$ & 21 & wahlbomiana & & $\ldots 48$ & 16 \\
\hline tanaceti & $\ldots$ & $\ldots 95$ & 33 & wahlbomiana & & ...15 & 0 \\
\hline tragonana & $\ldots$ & $\ldots 67$ & 22 & walsinghamur & & ...38 & 13 \\
\hline uetrana & & $\ldots 64$ & 21 & ana & $\ldots$ & $\ldots 53$ & 18 \\
\hline thulian & $\ldots$ & $\ldots 26$ & 10 & & $\ldots$ & $\ldots 51$ & 17 \\
\hline & ... & $\ldots 97$ & 34 & & $\cdots$ & $\ldots 2$ & 1 \\
\hline ella & $\ldots$ & $\ldots 14$ & 6 & zephyrana & & $\ldots 33$ & 12 \\
\hline na & $\ldots$ & $\ldots 90$ & 31 & zœgana & & $\ldots 31$ & 11 \\
\hline rigeminana & $\cdots$ & $\ldots 69$ & 23 & & & & \\
\hline
\end{tabular}


xiii.

\section{PREFACE.}

After gathering together a fair collection of the British butterflies and larger moths, I found, in company with many other collectors of the British Lepidoptera, that, to a certain extent, Rome was conquered, and fresh fields for study must be opened up. Often it is not until this poini is reached that the attention is turned to the "Micros," those marvellous little gems, of which many are so small that the keenest eye can hardly see to appreciate their beauty. Yet, with the perversity of human nature, it is not till the eye grows dim, that the average Lepidopterist begins his study of these fascinating objects. Possibly there is a reason for this otherwise unfortunate delay. The hand steadies, and becomes expert with practice, and the setting of a Micro, which would daunt a beginner, becomes easy to the experienced; hence the readiness in later life to attempt the more difficult. Thus after years spent in the preparation of the genitalia of the larger species, I decided to complete my collection of slides of the British Lepidoptera, and I now present the third volume of the series, which deals with the Tortricida. I have in this volume been fortunate in securing the co-operation of the Rev. J. W. Metcalfe, who, in his great love of the Science, and at no little sacrifice, has made the drawings as fast as I could obtain the specimens, and prepare the slides, and I take this opportunity of offering to him my grateful thanks for this most valuable help. The result has been to speed up the work, and had it not been for the terrible war, this volume, dealing with the Tortricida, might have been published in 1917. As this was impossible, I can now 
xiv.

present it in a more complete form, while some few species, then considered unprocurable, have come to hand, and enabled me to fill up most of the remaining gaps.

In the previous volumes the genitalia were drawn to scale, a fact whic' had in some respects a certain advantage; but it had also the disadvantage of reducing the figures of the smaller species so greatly as to destroy their value. After carefully weighing the pros and cons, we decided to keep the drawings fairly uniform in size, in order that the different and characteristic points, in even the smallest species, might be shown.

I have found the "Tortrix men" so generous in helping with specimens, many in cases of difficulty sending their entire series to "do as I liked with," that I have added the names of the donors to the species, so kindly provided by them, and I wish this to be a record of my grateful thanks.

The ever difficult question of the Nomenclature has been considered, although from the point of view of my particular study, the question of names is really a matter of no great importance. The generic names have been worked out with the aid of Mr. C. H. Fernald's "The Genera of the Tortricidæ and their types." Where we have been unable to find any existing generic name, we have left a blank space, and the same with regard to the type. So many genera have been created for foreign species, that, until these have been examined from a genitalic point of view, we have been averse to providing superfluous names for genera which may already exist. These blanks may be filled in as our knowledge increases. For the specific names I have relied mainly on the type collection in the Victoria Museum at Manchester, named by Mr. J. H. Durrant, and to him I am indebted for much help in this, and other matters.

I believe the compilation we have arrived at to be 
the most natural classification at present attainable, but we refer further to this point in the Introduction.

I should like to state that I have already made progress in the study of a large number of species of the Tineida. The acquisition of the late Mr. A. C. Vine's almost complete collection will greatly expedite the microscopical part of the work, and I hope to publish, at no distant date, an account of the Genitalia of the Tineida.

F. N. PIERCE.

The Old Rectory,

WARMINGTON,

Oundee, Northants.

23rd November, 1921. 
$x v i$.

\section{INTRODUCTION.}

If it be asked what is the most arresting result of our prolonged study of the genitalia of the Tortricida, we should be inclined to reply, the way in which the species fall into clearly defined groups. In other words, the genitalia are strongly generic in character, and it is possible to place, at once, a species in the group to which it belongs. If it be further asked what light the genitalia shed on the historic relationship of the groups or genera, we have to confess that it is very little. This is not to be wondered at; the fact that the genera are so clearly defined shows how many connecting species have ceased to exist; and, further, the British species form but a part of the whole. Nor is it yet possible to say where the Tortricida should be placed amongst the Lepidoptera. We find a connecting link with the Geometrida, where the characteristic hinged, and, much curved penis of the Tortricida, appears in the Chesiadince, notably in Anaitis plagiata, where also there is a kindredship between the females; and in the Tortrixlike form of Odezia atrata; but clearly a phylogenetic tree, from the genitalic point of view, is not yet possible.

When we come to specific differences the position is quite otherwise. Here the differences, although constant, are sometimes extrernely small, and in these cases it was necessary to make many preparations before they could be detected. Within the groups it is possible to secure a perfectly natural sequence.

In the present volume we have gone further than in the two previous ones, and present a definite scheme of classification, based entirely on the genitalia. We rate very highly the classificatory value of the genitalia, on the 
ground, that, upon the form of the genitaliz the segregation of species depends, and, further, that changes in the process of development, which would amount to the formation of a new species, must of necessity be reflected in the form of the genitalia, if that deveiopment is to be made permanent. 'I'hus, while fully admitting that the final classification can only be arrived at upon the study of all the characters, we feel confident that the present arrangement marks a big step towards the goal, and our confidence is strengthened by the close agreement of our results with those of Mr. E. Meyrick, which were reached by the study of other structural characters.

A word must be said with regard to the names employed for the different parts of the genitalia. The most recent work of importance on the subject is contained in Professor N. J. Kusnezov's “Introduction to the Fauna of Russia," Petrograd, 1915, wherein he treats of the names of the parts as used by various authors. This work was published directly after the publication of "The Genitalia of the British Geometrida," but the author was only acquainted with the previous volume on the British Noctuida. We are therefore unable to accept his names for the parts that had already been named in "The Genitalia of the British Geometrida."

After full consideration of what has been written in criticism of the names employed in that work, we find no reason for changing them, and we accordingly employ them in this present volume, referring our readtrs to the former for definitions and descriptions. We are quite satisfied that the parts of the Tortricid genitalia are homologous with those found in the Geometridce, and we are averse to creating new names for mere modifications of the same organs. Some day it may come to be generally recognised, that, as we believe, the genitalia in all orders of insects are built upon a common 
xviii.

plan, although greatly modified in detail, and a reduction and simplication of names be arrived at, which is much to be desired.

It is necessary at this point to refer to some characteristic features of the Tortricid genitalia. One very distinctive character is the form of the penis, which is cardinate or hinged, and much curved. It bears a strong resemblence to a pistol, and we have already noticed the curious occurrence of this form at the end of the Geometers, in the Chesiadina. Dealing with external parts of the tenth abdominal segment in the male, we note that the uncus is largely undeveloped, and, with the exception of a few groups, the same may be said of the gnathos. On the other hand the socii are generally large and prominent; they may be erect bergmanniana pl. vi., or drooping osseana pl. vi., the latter being the more usual form. The transtilla is strongly developed in some of the groups. The anus is generally a thin membraneous tube. In the ninth segment, the tegumen (with the exception of its ventral portion, the saccus), is strongly developed. The iatter is very short, and in the group Phaloniadii, we find it in a very instructive condition. Here the two arms of the saccus are disconnected, and in certain Tineida they are similarly disconnected, and also very long. From this it seems clear that the saccus is really a development of the two projections which hinge the body segments together, and which are so conspicuously developed in the anal segments of the female. We have also found examples where these connecting rods unite the uncus and gnathos in the ninth segment.

In the valvæ, the costa, valvula, and sacculus are almost universally fused together. A striking exception to this is found amongst the species of the genus Phalonia. Here in three of the four species the costa leaves the valvula completely, and, entirely altering its position, seems to 
form a new organ, or one that might easily be mistaken for some other part. In the fourth species, rupicola, the costa reverts to its normal position. The four species are, however, most closely allied in all other directions, and thus it is clear, the sacculus being often quite distinct, that the valva is a composite organ, composed of three separable parts.

The term harpe is always rather indefinite, and in the Tortricida would generally be synonymous with the costa, we therefore do not employ it.

In the Geometridce the term furca was employed in those cases were the sacculi were separated from the valvulæ, and united centrally, so as to form one organ. The term, it appears, had already been employed to represent other organs in the Lycanida. In the present volume we therefore describe such cases by saying that the sacculi are centrally united.

The eighth segment, as we should expect from the fact that the genitalia are not withdrawn behind it, is remarkably devoid of ornamentation, though occasionally coremata exist.

We have been criticised for dividing the parts and organs by the expressions external and internal. We would point out that some parts develop within the abdomen, and only become external at the end of this process, at which time they also become fused to the tegumen. These parts we call the internal parts, but we have to admit that the valvæ should, strictly speaking, be reckoned with them. The penis, as we nave said, is very characteristic of the family. The ædœagus is generally much curved, and hinged to the centrai, shield-shaped, juxta; thus the elaborate arrangement surrounding the penis, so prominent in the Geometrida, is rendered unnecessary. The ædœagus is as a rule simple, sometimes it is dentate, very rarely branched. The vesica is not only 
$x x$

armed with cornuti in the form of fixed spines, which, notwithstanding, may sometimes be broken off during copulation, but they are usually accompanied also by long, flattened, almost fish-shaped, deciduous spines. These latter remain in the bursa of the female after copulation.

Turning now to the female, we draw attention to the ovipositor. This usually consists of a pair of flattened lobes, clothed with fine spines. Some specialized forms, however, appear. The first is telescopic, clearly developed to meet the case where the ovum has to be deposited far down, e.g., within a long rolled grass leaf. The second is the highly specialized form we have called floricomous. It occurs in the group Cnephasidii, and, in a less developed stage, in Tortrix viridana, $L$. and Zeiraphera trimaculana Don. Some light has been shed upon this curious form by the interesting observations of Mr. A. Sich; in these he records that the eggs of Tortrix viridana are laid in pairs, and then covered with green scales from the upper surface of the anterior wings. For this purpose the highly specialized floricomous ovipositor would be eminently suitable. Other peculiar forms, occurring sporadically in genera with usually normal ovipositors, point clearly to specialization; e.g., the strong form designed for cutting purposes, as in Commophila aneana.

The ostium is commonly in the form of a cup, but the ductus bursæ is often useful in separating otherwise closely similar species. The signum is highly important, and we have relied largely upon it in forming the larger groups. In certain cases, it is true, it is absent, but here the form of the male genitalia leaves no doubt as to the position the female should occupy. We are unable to make any suggestion as to the use of the signum, and find its occasional absence equally unaccountable. In accordance with this character we arrive at the nine following large groups :- 
Archipsidii: Signum a single smooth horn with bulbed base.

Cnephasidii: Signum a dentate band.

Peroneidii: Signum a single stellate plate.

Phaloniadii: Large dentations covering the bursa.

Olethreutidii: Signa two scobinate cirsles or discs; or a pocket.

Ancylisidii: Signa two triangular hollow plates.

Epiblemidii : Signa pilleate.

Ephippiphoridii: Signa two horns.

Lipotychidii: Signa one horn.

By means of our investigations we have had the pleasure of adding some new species to the British list, viz. :Cnephasia genitalana, E.M.M. Vol. 51, 1915, p. 8. Eudemis pomedaxana, E.M.M., Vol. 51, 1915, p. 9. Lipoptycha cratana, E.M.M., Vol. 51, 1915, p. 10. Lipoptycha torrana, a species still awaiting description. Peronea fissurana, E.M.M., Vol. 51, 1915, p. 327. Astatia sinuana, which has hitherto been considered merely a variety of $A$. solandriann.

Epiblema littoralana, E.M.M., Vol. 51, 1915, p. 327.

On the other hand, we can find no difference from a genitalic point of view, between the following pairs of species :-

Argyroploce carbonana ind A. nigricostana.

Argrotoxa schalleriana and A. perplexana.

Celypa striana and C. purpurana.

Spilonota ocellana and S. lariciana.

Rhopobota nœvana and R. geminana.

In view however of the minute differences, which none the less when detected, are found to be constant, separating other pairs of species; and in the face of the apparently great and constant differences in the wing markings of the above pairs, we do not feel able tc pronounce positively upon their identity. 
xxii.

In a few species the genitalia appear to be in a plastic condition, and we find considerable variations. Our conclusion is that the species are actually in the process of being differentiated into two or more.

Epiblema pflugiana affords a good example. Here we meet with at least three forms, very distinct externally; (i) the large pale form with the smaller dark female (scutulana); (ii) the middle form in which both sexes are of the same size, and both have dark hind wings (circiana); (iii) a small form taken in the Fens. This last appears most closely allied to the first, but the genitalia give no constant character on which to separate any of the three.

Catoptria scopoliana and C. parvulana may be another case of two species in process of differentiation.

A valuable result of our work will be the practical aid it affords in separating species of very similar and often indistinguishable appearance; e.g., the Cnephasias. Often it will be found possible to determine a specimen, without mounting the abdomen, or in any way damaging it, by means of the genitalia. It would much facilitate later examination of any doubtful specimen, if at the time of setting, a dorso-ventral squeeze were given to the end of the abdomen with a pair of fine pointed forceps. This would have the effect of extending the valvæ of the male genitalia. An example of this practical value of the examination of the unmounted genitalia will be found in the plate of the Cnephasias given in the Entomologist's Record, Vol. 27, 1915, pl. iii.; another was given by Lord Walsingham, E.M.M., Vol. 34, 1898, pl. ii. With the help of the drawings given in this volume we think there will be little difficulty in separating many other closely allied species.

NotE.-The numbers placed in the text after the specific names indicate the number of mounts, male and female respectively, made of that species. 
Classiffcation of the British Tortricidx based on the structure of the male and female Genitalia.

\section{TORTRICIDAE.}

\section{ARCHIPSIDII,}

Male with valvæ broad. Uncus, Gnathos and Transtilla weli developed; Cornuti deciduous. Female with Ovipositor flattened; Signa a single smooth horn with bulbed base.

Gends 1. Argyrotæenia, Stp. TYPe politana, Haw. Argyrotzenia politana. Haw. $2-1$

Valva distinctly rounded; transtilla indent. Cornuti 9-10, very broad, short, pointed (apple pips).

Ductus bursæ narrow, a strong thickening at the junction with the bursa.

Genus 2. Archips $H b$.

TÝPE piceana, $L$.

In the male the valvæ are broad with the sacculus well developed. Uncus strong, generally long, with gnathos well developed. Transtilla a simple band, strong. Cornuti deciduous.

In the female the ovipositor angulated, flattened. Ostium generally with well divided operculum. Ductus bursæ very long, narrow. Signum long, horn shaped.

Archips piceana, $L . \quad$ S. J. Capper $1-1$ Valva rounded; sacculus long curved not reaching margin of valva. Uncus cylindrical, apex rounded and flattened; gnathos pointed. \&\&@œagus sharply pointed; cornuti three, long.

Ostium wide with central lobe behind. Signum long, base short, rounded. 
Archips decretana, $T r . \quad$ A. E. Atmore $\quad 1-1$ Sacculus long curved extending just beyond margin of valva. Cornuti long, about 12-14.

Ostium wide, deeply cleft in front, central lobe behind very small.

Archips podana, Scop. $5-7$

Sacculus broad, curved, not reaching margin of valva. ÆEdœagus angularly pointed; cornuti 5-6.

Ostium wide, deeply cleft in front, central lobe behind small constricted.

Archips cratregana, Hb. A. E. Atmore 1-1 Sacculus encroaching centrally, pointed, not reaching margin of valva. Edœagus not curved, short; cornuti 3.

Ostium rather narrow, without operculum. Signum comparatively short, flattened, with small base, without scar.

Archips xylosteana, $L$.

Sacculus encroaching centrally, tips rounded, not reaching margin of valva. Cornuti 5 .

Ostium without operculum. Signum short, base rounded, with considerable scar.

Archips rosana, L. W. Mansbridge $5-3$ Sacculus encroaching centrally a considerable distance from margin of valva, tip pointed. Uncus wider above. Ædœeagus straight with long, slender, projecting spine at apex. Cornuti 3-4.

Ostium narrow, without operculum. Signum comparatively short, base extended, curved, scar well marked.

Archips sorbiana, $\mathrm{Hb}$. 4-1 Sacculus bluntly rounded, not reaching margin of valva. Uncus short, broad, socii developed. AEdœagus truncate, with angulated point. Cornuti 6 . 
Signum comparatively short, base slightly extended, scar small.

\section{Archips diversana, $H b$.}

J. W. M.

1- 1

Genitalia small compared with size of insect.

Valva miuch reduced. Sacculus strong, obtusely pointed, reaching beyong valva. Uncus clavate; socii large. Æ̇dœagus slightly spiral, tip curved, pointed. Cornuti 8. Octaval bilobed with inwardly projecting central rod.

Signum fairly long, without base, scar large.

Archips musculana, $H b$. 3-1 var musculinana, $K n l$.

W. Claxton $1-0$

Both male and female show close connection to this group.

Valva full; sacculus broad, bluntly rounded before the margin. Edœagus slightly ridged, with points; cornuti long, 3-4.

Ductus bursæ sharply narrowed. Signum short, pointed; scar scobinate.

Genus 3. Pandemis, $H b$.

TYPE corylana, Fab.

The heavy coremeta of this group confirm the wisdom of excluding these non-folded costa species from the former group.

Valva full; sacculus not free; transtilliw a simple band. Uncus usually broad; gnathos only free at the tip. Cornuti large, deciduous.

Ostium without operculum; ductus bursæ fairly long.

Pandemis corylana, Fb. W. Mansbridge 2-1 Valva very full, rounded. Uncus very broad, few fine spines. Edœagus curved; cornuti strong, geniculate towards the base, 2 .

Ostium wide, ductus bursæ sharply narrowed, bụt widens immediately to the bursa. Signum short, with large base and large scar; bursa has also two ovate, scobinate patches. 
Pandemis ribeana, $H b$.

Transtilla indent. Uncus broad, many fine spines. Æ̇dœagus geniculate; cornuti very strong, 2.

Signum short, slightly dentate.

Pandemis heparana, Schiff. Uncus very broad, set with coarse spines on either lobe. Æddoagus geniculate, with ridge of spines, a small one at apex; cornuti large, 3 .

Signum short, base rounded, scar lon๖.

Pandemis dumetana, $T r$. $2-0$

Lady Robinson, Messrs. Atmore, Adkin, Gardner, Whittle and Ford have all tried to send female of this species, but so far I have failed to obtain this sex. Mr. Thurnall examined his series, all were males. The Honble. N. C. Rothschild informs us he has a female in his collection.

Valva rounded, produced above; sacculus slightly extending beyond the margin of valva. Uncus very broad, bilobed at apex; gnathos narrow, rounded point. Cornuti strong, 2.

Pandemis cinnamomeana, Tr. J.W.M. 2-1 Sacculus narrowed to fine line. Uncus very broad, slightly indent; gnathos sharply pointed. Cornuti sharply geniculate towards base, 2 .

Signum short with projecting arm; base large, rounded; scar large.

Pandemis lafauryana, Ragt.

Valva triangular, apex with patch of long scales; sacculus angular with long projecting spine, afterwards curving upward. Cornuti 10-11. Anellus lobes broad.

Ductus bursæ narrow, very long, scobinate at the junction of the bursa. 
The female seems to indicate the genus Archips, the coremata of the male the genus Pandemis, thus forming a connecting link.

Genus 4.

TYPE

\section{unifasciana, Dup.}

This species starts a new group with the pointed sacculus and dentate transtilla.

Pandemis lafauryana is the connecting link, the sacculus being developed but the transtilla remaining simple.

Valva much reduced; harpe a ridge set with eight or nine long, curved, articulated spines; sacculus short, with point on outer margin. Transtilla divided, arms coarsely spined. Uncus very broad. A\&dœagus almost straight with central projecting narrow spine; cornuti 3.

Signum curved, dentate on edge.

Genos 5. Clepsis, Gn.

TYPE rusticana, $T r$. Valvula weak set with long scales; sacculus not free, sometimes spined; transtilla dentate, often separated. Uncus broad; gnathos strongly developed. Cornuti deciduous.

Ductus bursæ fairly short. Siguum horn-like, with bulbed base.

\section{Clepsis rusticana, $T r$.}

Valva small; costa with projecting spines; sacculus angulate with central arm; transtilla divided, coarsely spined. Uncus broad; gnathos broad. સEdœagus almost straight, with curved projecting spine; cornuti 2. Anellus lobes large, spatulate.

Ostium edge thickened rather elaborate; ductus bursæ considerably shorter and wider than preceding species; signum curved, base strong, scar large, roughly scobinate.

Clepsis costana, Fab.

W. Mansbridge 1-1

Costa produced towards base, set with bunch of spatulate 
scales; transtilla divided spined. ÆEdœagus straight; cornuti 13-14.

Ostium central lobe behind; ductus bursæ narrow, short; signum short, wide, base rounded.

Genus 6. Lozotaenia, Stph. TYPE forsterana, Fab.

\section{Lozotaenia forsterana, Fab.}

Valva triangular; transtilla indent, lobes dentate. Edœagus angularly spined at apex; cornuti 3 .

Ostium narrow; ductus bursæ finely spined above.

Lozotaenia semialbana, $G n$. $\quad 1-1$

W. Purdey, R. Adkin; the female, The Hon. N. C. Rothschild.

Valva long, rounded; transtilla dentate. Uncus broad, tapered. Adøeagus short; cornuti long, 5.

Ductus bursæ short, narrow; signum pointed, base rounded, scar large.

\section{Genus 7. Philedone, $H b$. Type gerningana, Schiff.}

Philedone gerningana, Schiff.

Male, Lady Robinson; the female body I obtained thus :In the Threlfall cabinet was a female wing parts and a number of loose bodies in the drawer; these I prepared and found one different to any other species, this I concluded was the female of this species.

Transtilla broad, squared, scobinate, spatulate. Gnathos broad. Edœagus short with protruding lip; cornutus a single spine set in a peduncle, dentate at the cup.

Ostium very wide; ductus bursæ short; bursa simple.

Genus 8.

TYPE

cinctana, Schiff.

Messrs. Whittle, Purdey, and Porritt.

Sacculus with slight obtuse projection; transtilla 
divided, finely spined. Edœagus with ridge of spines. Cornuti absent.

Ductus bursæ narrow, rather long; signa absent.

Genus 9. Epagoge, $H b$. TYPE grotiana, $F a b$.

Epagoge grotiana, Fab. J.W. Tutt

$1-1$

Transtilla weakly chitinised, set with long slender spines. Cornuti long, 7.

Bursa simple; signa absent.

Genus 10 Ptycholoma, Stph. Type lecheana, $L$.

Ptycholoma lecheana, $L$.

Valva triangular, heavily set with long clavate scales; sacculus short, strong, pointed; transtilla bilobed, set with spines. Adoeagus squared at the apex, forming two points, one very long; cornuti short, very slender spines, 3-6.

Ostium deeply cleft, strongly chitinised lobe behind; signum broad, short, sharply tapered.

Genus 11. Capua, Stph. Type favillaceana, $H b$.

Capua angustiorana, Haw. $\quad 5-2$ Valva elongate, squared; transtilla simple band. Uncus short, wide, squared; gnathos only free at the tip, rounded. Cornuti short, not deciduous, 3 .

Ductus bursæ rather long; signum short, small scar on bursa.

Capua favillaceana, $H b$.

Messrs. Lofthouse and Adkin 2-1 Closely allied to cinctana, gerningana, and grotiana, probably connecting links to Cnephasia, nearest species to pronubana.

Sacculus elaborate, terminating in two spines; transtilla a simple band. Æ̇dœagus curved, obtusely pointed at apex; cornuti absent.

Ostium wide; ductus bursæ soméwhat long, bursa simple; signa absent. 
Genus 12 .

TYPE

pronubana, $H b . \quad 1-1$

Adkin and Mansbridge

The long ductus bursæ seems to connect this with species in the genus Archips, but the nale genitalia does not bear this out.

Valva reduced; sacculus elaborate, a long spine beyond the middle, followed by a short one, apex rounded and free; transtilla a strong bridge produced and lob $\div$ d at either side. Uncus broad, indent. Edœeagus hardly curved, protrudes from a pair of long anellus lobes, spined at the apex.

Ductus bursæe long, slender; signum very small, dentate, double pointed.

Genus 13. Amelia, $\mathrm{Hb}$.

TYPE viburniana, Fab.

Amelia palleana, $H b$.

The elaboration of the gnathos suggests a separate genus for these species.

Valva broad; sacculus strongly thickened, transtilla sides almost parallel. Uncus broad, rounded above; gnathos pointed, before the junction with the tegumen at either side is a long lobed arm. AEdocagus short, with protruding central spine, apex with obtuse spine; cornuti long, slender, 2.

Ovipositor flattened normal. Signum long, slightly dentate, base lobed.

Amelia viburniana, Fab. $5-3$

Cabinet specimens of this and palleana when similar in colour can easily be determined by examination of the generally protruding uncus which will show either indent or rounded.

Valva short, tapered; sacculus tips free, pointed; transtilla indent, lobes strongly spined. Uncus deeply emarginate above; gnathos pointed, at either side is a strongly dentate arm. Ædœeagus broad; cornuti absent. 
Ovipositor specialised not flattened. Ostium narrow, at either side is a deep triangular sac; ductus bursæ long; signa very small, double pointed.

Amelia prodromana $H b$.

Lady Robinson, Messrs. Whittle and Gibbs.

Valva reduced; sacculus short, pioduced, lobed; transtilla a simple band. Uncus broad, tapered, apex squared, indent; gnathos pointed, at either side is a long, pointed arm. Edœagus emarginate at the apex; cornuti short, 5, broad daggers springing from weak peduncles.

Ovipositor specialised, two complete ovate pads. Ostium wide; ductus bursæ scobinate above; signum obtusely pointed.

Genus 14. Eulia, $H b$. TYPE ministrana $L$.

Eulia ministrana $L$. $3-1$ This species requires a separate genus on account of the acicular ædoagus and the pannicular bursa. The only instance of this geometrid form of bursa we have found among the Tortricida.

Valva elongate without sacculus, transtilla extended in a pair of long curved spines. Ĺncus narrow, wider above, indent; gnathos wide, spatulate, almost square at the tip. Edœeagus acicular, cardinate.

Ovipositor flattened, normal. Ostium narrow, with side guides; ductus bursæ fairly short, bursa pannicular.

\section{CNEPHASIDII.}

This group divides into several genera which are closely related. Hitherto a very difficult group to determine by wing markings, but examination of the genitalia in dried specimens removes all difficulties. We gave a plate exhibiting the appearance of the underside (ventral) of the male genitalia in dried specimens by which any species may be identified, in the Entomologists Record, 1915, p. 99 . 
Male with valvæ elongate. Uncus well developed. Cornuti generally absent. Female with floricomous ovipositor.

Signum a dentate band.

\section{Genus 1. Cnephasia, Curt. type pasivana, $H b$.}

Valva elongate, sacculus well developed terminating in a tuft of aglutinated spines; tegumen high. Uncus heavily and minutely spined; socii drooping. AEdœeagus cardinate, cornuti absent, except in incertana and abrasana.

Ovipositor floricomous except in incertana and abrasana. Signum a long, scobinate band.

Cnephasia incertana, $T r$. A. Lofthouse 6-4 The retractile ovipositor and long uncus without the minute spines but set with hairs, and the broad gnathos, seem to place this and probably abrasana in a separate genus.

Valva curved; sacculus brought well inwards toward the centre. Uncus long, set with long regular hairs, tip dentate; gnathos broad.

Ovipositor retractile. Ostium narrow; signum short, sides parallel, dentate.

Cnephasia abrasana, Dup.

This species has been introduced into the British list, but so far we have failed to find any British example. The true abrasana is in the collections of Heinemann and Frey in the British Museum. The preparation here given is a male from a series of four specimens in Dr. Mason's Continental types. Of the four specimens two had no body, another was a female with a floricomous genitalia to the glued-on body, and one a true abrasana male

Valva straight; sacculus very short, broad, with large tuft of spines (chrysantheana form). Uncus set with long regular hairs. 
The female has a soft, rounded ovipositor. It may be extensile. Hofmann Ento Annual, 1873, p. 54, says : “We find the pointed form of ovipositor.", But as we have been unable to obtain a specimen for preparation, we can only judge from the dried specimens, which are certainly different from incertana.

Cnephasia conspersana, Dougl. R. Adkin, J. Gardner.

Valva slightly curved; sacculuc extending one-half, inwardly, tips long, free, reaching the costa. Uncus minutely spined. Ædœagus pointed, with obtuse spine (rose thorn).

Ovipositor floricomous. Ductus bursæ comes straight down on the right side, narrows and is thickened on the ieft side; signum long, dentations double.

Cnephasia longana, Haw.

Valva straight, sharply pointed; sacculus short.

Ductus bursæ narrows from either side; signum scobinations disjointed, slightly widening.

Cnephasia pasivana, $H b$. $4-3$ Whittle and J. W. M.

Valva straight, pointed; sacculus extends beyond one-half, produced along the outer margin.

Ductus bursæ not narrowed, short, sides not thickened. Signum narrow.

Cnephasia chrysantheana, Dup. $3-2$ Lady Robinson, Whittle and Mansbridge. Valva straight, bluntly rounded; sacculus extends threequarters. Edneagus with small rounded keel before the orifice

Ductus bursæ short. Signum very long, piriform.

Cnephasia octomaculana, Haw.

Lady Robinson, Whittle and J. W. M.

Valva straight, bluntly rounded; sacculus more than 
one-half, but less than three-quarters. Fdœeagus with small rounded keel before the orifice.

Ductus bursæ short; signum long, piriform.

We are unable to detect any difference between the female of this species and chrysantheana.

Cnephasia communana, $H$-S.

Mansbridge (Thurnall's Specimen), and J.W.M.

We confirm Barrett's opinion, Lep. B. Isles, Vol. x., p. 264, that these specimens are a distinct species, but whether they are the communana of H.S. or not, we have no means of ascertaining.

Valva straight, bluntly rounded indent before sacculus; sacculus almost three-quarters. Uncus minutely spined narrows more quickly than preceding two species. Ædœagus with dentate ridge.

Ostium triangular; ductus bursæ bulbed at either side; signum piriform.

Cnephasia virgaureana, $T r$.

Richards and G̈ardner.

Valva with edges parallel, margin squared; sacculus extended the lengtil of the valva. Ædoeagus stout, stumpy, with serrate rounded keel before the apex.

Ductus bursa very weak; signum evenly piriform.

Cnephasia genitalana, Pierce and Metcalf. 3-3 $R$ Adkin and J. W. M.

Valva short, obtusely pointed; sacculus very long, strong, extending beyond the valva, much curved. Edœagus - slender, pointed; vesica evenly scobinate.

Ductus bursæ geniculate, narrowed; signum long, double row of teeth.

Genus 2. Nephodesme, Hb. TYPe penziana, Thunberg. The distinct modification of the uncal parts; the absence of gnathos; the spined transtilla, warrant a separate genus for this group. 
Valva long, curved; sacculus developed, not spined at apex. Tegumen high. Uncus distinctly articulated to the tegumen, deeply lobed at either side; socii drooping; gnathos rudimentary. Transtilla developed.

Ovipositor floricomous. Signum scobinate.

Nephodesme incanana, Stph. $4-2$ Messrs. Gardner, Corbeti and Sheldon.

Valva long; sacculus extending one-half, much curved. Transtilla angularly arched, minutely spined.

Ductus bursæ weak; signum long, dentate, wider below.

Nephodesme bellana, Curt. = penziana, Thnb.

G. F. Whittle and C. S. Gregson.

There is a constant difference between this and colquhounana in both sexes, which we consider sufficient to demand their separation.

Sacculus extending one-half, much curved. Transtilla broadly arched. Socii not free, sharply pointed to a spine, well chitinised.

Ostium strong; signum long, narrow, dentate.

Nephodesme colquhounana, Bar.

G. F. Whittle and R. Adkin.

Transtilla sharply arched.

Ostium cleft, bursa without signum.

Nephodesme osseana. Scop. $3-1$

Sacculus extending over half, slightly curved, pointed. Transtilla very slightly arched. Uncus with tapering lobes minutely spined.

Ostium small, with large angular plate. Signum very long, doubly dentate. 
Nephodesme argentana, Clerck.

R. Adkin and J. W. M.

Sacculus extending half, curved to emargination. Transtilla slightly arched. Uncus with tapering lobes minutely spined. Edœeagus short, stout, with sharp spine at base, apex forming a cap for the vesica.

Ostium small with large angular plate, sharply angulated ventrally.

Nephodesme nubilana, $H b$.

P. Richards, J. Gardner and J. W. M.

Sacculus extended nearly two-thirds pointed with central arm. Transtilla produced in short central point. Uncus narrow: without side lobes, minutely spined. Edœagus curved, dentate at apex.

Ostium wide, sides of plate produced. Bursa very small. scobinate.

Genus 3. Tortricodes, $G n$. TYPE tortricella, $H b$.

Tortricodes tortricella, $\mathrm{Hb}$. 2-1

Although closely allied, there appears sufficient modification to denote a new genus.

Valva irregularly incised; sacculus brought well towards interior of valva, produced in flattened plate (keel). Uncus set with hairs and short spines; socii drooping; gnathos strong, pointed. Uncus with a pair of side arms, one short, narrow; the other very long, slender.

Ovipositor floricomous. Ostium narrow, plate a crescent. Bursa very delicate; signum small, spined.

Genos 4. Enyphantes, Hb. TyPE congelatella, Clerck.

Enyphantes congelatella Clerck. $2-3$

Although closely allied, there appears sufficient modification to denote a new genus.

Sacculus not free, with projecting arm. Transtilla curved, hairy. Uncus very broad, pointed; socii widely 
separate drooping; gnathos only free at the tip, which is rounded. Ædoeagus small, cardinate.

Ovipositor floricomous. Ostium exceedingly small. Bursa so small and delicate as to be practically invisible.

Genus 5. Sciaphila, Tr. TYPE wahlbomiana, $L$. Sciaphila wahlbomiana, $L$.

The type specimen, which still exists in the Linnean collection in London is a rather grey almosit typical example cf a male Argyroploce branderiana. Moreover Linné's description of wahlbomiana agrees with this insect. Of branderiana he only describes the female.

Branderiana having priority of paging and the specimen described being a female, the name niust stand, and wahlbomiana becomes a synonym of branderiana.

Thus the much discussed "omnium gatherum" wahlbomiana disappears from the group Cinephasia.

Genus 6. Olindia, Gn. TYPE ulmana, $H b$.

Olindia ulmana, $H b$. 2-1

A. Lofthouse and J. W. M.

Valva long, sides parallel, the central opening thickens and extends towards the anal angle, terminating in a socketed spine; sacculus set with fine spines. Transtilla produced at either side in a long dentate arm. Uncus deeply cleft centrally; socii small, drooping; gnathos strong, tip bilobed. Anellus lobes spined.

Ovipositor flattened thickly clothed with spines and hairs. Ostium wide spined; bursa simple.

GENUs 7. Isotrias, Myk. TYPE rectifasciana, Haw.

Isotrias rectifasciana, Haw. 3-1 G. F. Whittle.

Valva long, rounded, the central opening thickens and extends towards the anal angle, terminating in a socketed spine. Sacculus set with curious digitated spines. 
Transtilla a band. Uncue long, tapered; socii drooping; gnathos fairly strong, tip bilobed. Anellus minutely spined.

Ovipositor flattened. Ostium small; ductus bursæ narrow; bursa with long scar of three scobinate rounded plates at intervals.

Genus 8.

TYPE

Rev. C. R. N. Burrows.

conwayana, Fab.

$4-2$

Conwayana has a very distinct form of genitalia allied to the Cnephasia group.

Valva curved; sacculus extending one-half; tip rounded and spined. I'ranstilla rounded, squamous. Uncus widest In centre; socii drooping. Edœeagus pistilate, set with a patch of 12-14 tiny spines; anellus strongly chitinised, produced.

Ovipositor flattened, fused. Ostium cleft, wide. Bursa slightly scobinate.

\section{PERONEIDII.}

Valvæ elongate. Uncus atrophied; socii very large.

Ovipositor flattened. Ostium plate emarginate, forming two lobes. Signum a single stellate plate.

The erect and strongly developed socii suggest a division in this group. The produced and separate valvula runs throughout. The presence or absence of cornuti is difficult to understand. Meyrick gives bergmanniana as the type of Argrotoxa Steph, we have therefore adopted this name for the group of species with erect socii.

\section{Gexus 1. Argrotoxa, Stph. TYPE bergmanniana $L$}

Valva long; costa thickened; valvula small, extruded. Uncus atrophied; socii erect, large; anal tube strongly chitinised, often with a hook at the orifice, probably an gnathos atrophied. A£dœagus short, stumpy. Vesica with or without cornuti.

Ovipositor flattened. Ostium plate emarginate forming two lobes. Signum more or less ovate, scobinate. 
Argrotoxa bergmanniana, $L$.

W. Mansbridge.

Sacculus gently incurved. Socii large, curved, wide. Edoeagus short, stout; vesica without cornuti.

Ovipositor dark coloured. Ostium plate lobed, lobes short; signum ovate, scobinate, variable.

Argrotoxa comariana, $Z$. 7-1

Valvula rounded; sacculus abruptly cut before half, forming an almost rectangular emargination; anus with small projecting plate. Socii slender. Cornuti absent.

Ostium plate with narrow, pointed lobes. Signum small scobinate scar.

Argrotoxa potentillana, Cooke, appears to be a variety of this species. We can find no difference in genitalia.

\section{Argrotoxa schalleriana, $L$.}

Sacculus indent in a narrow rounded emargination, note of interrogation (?) form. Anal tube minutely spined. Cornuti one large, about twelve small, spiniform.

Ostium plate with narrow pointed lobes. Signum absent.

Argrotoxa perplexana, Barr.

Rothschild, Threlfall Col.

This appears to be a variety of schalleriana. We can find no difference in the genitalia, but would point out that the differences in this genus are usually very slight.

Argrotoxa comparana, $\mathrm{Hb}$.

Very similar to schalleriana. Cornuti spiniform, five small, one larger; the number of cornuti appears to vary. We hesitate to declare it separate from schalleriana.

Ostium plate with narrow pointed lobes. Signum absent. 
Argrotoxa caledoniana, Steph. $3-1$

W. Mansbridge, P. Richards, A. Lofthouse and G. F. Whittle.

Saccuius emargination wide, and rounded. Anal tube without minute spines. Cornuti $2-4$ extremely fine spines.

Ostium plate with short, narrow, pointed lobes. Bursa scobinate, without signum.

Gends 2. Eclectis, $H b$. Type hastiana. $L$. J.W.M.

The modification of the socii and other developments denote a separate genus.

Eclectis hastiana, $L$

Valvula fairly large; sacculus with projecting arm at half. Socii entirely erect, anus simple. \&ddœagus slender; cornutı 11-12 slender.

Ostium plate with long, broad lobes; ductus bursæ broad with a small projecting protuberanre at either side. Signum stellate, rounded.

\section{Eclectis logiana, Schiff.}

J. W M., A. C. Vine.

The genitalia of the male is so similar to hastiana that the only difference we can detect is the slightly narrower valvula.

There is abundant difference in the female.

Ostium plate with short, narrow lobes; ductus bursæ very thort, simple; signum stellate, piriform.

\section{Eclectis sponsana, Fab.}

Sacculus cut obtusely at half. Uncus strongly chitinised, atrophied, wídely indent; socii erect. ZEdoeagus curved; cornuti two sets, one rose thorn, one or two spiniform.

Ostium plate with short, pointed lobes; ductus bursæ strong, bulbed near orifice. Signum stellate, ovate, variable. 
Genus 3. Aleimma, $\mathrm{Hb}$.

TYPE loeflingiana, $L$.

The floricomous ovipositor and general development seems to warrant a separate genus.

\section{Aleimma loeflingiana, $L$.}

Valva long; costa partly separated from valvula; Eaccuius thickened, not free. Uncus weak socii drooping, large, rounded. Edoeagus cardinate; cornuti absent.

Ovipositor floricomous, a very beautiful example of this interesting form. Ostium weak; ductus bursæ narrow; i ignuni a flattened ridge (keel).

Genus 4. Tortrix, $L$.

TYPE viridana, $L$.

Viridana is the type of the Linnean genus Tortrix; the cenitalia remove it from the remainder of the species usually included in this genus. Viridana is in every respect allied to the Peroneidii and belongs to the group with drooping socii, the long ædœeagus with spiniform cornuti. In other sespects the valvula, sacculus, and development of the anus coincide with the other sections of the group. The specialised ovipositor of the female has no value as a characteristic of the group and can therefore only rank as a specific character. Mr. Alfred Sich has, by careful (ibservations, recorded that the female lays her eggs in pairs, which are then covered with green scales. By means of the ovipositor she collects these green scales either from her own upper wings (a seemingly impossible feat) or equally improbably from those of her mate. All we know so far is, that the ovipositor is specialised, and contains these green scales by accumulation. It is thus evident that the following portion of the Peroneidii should form the genus Tortrix L.

Valva long, sides parallel: sacculus thickened. Uncus atrophied, indent; socii long, drooping. Edocagus cardinate; cornuti spiniform.

Ovipositor flattened. Ostium plate lobed; signum scobinate, stellate. 
Tortrix viridana, $L$.

A. Sich. 12-2

Sacculus slightly indent beyond middle. Cornuti spiniform, 6-8.

Ovipositor partially floricomous. Ostium weak; ostium plate hardly lobed; ductus bursæ wide, thickened at the junction of the bursa; signum small, spined at the extremity.

Tortrix forskaleana, $L$. $2-1$

Sacculus undulating. Ædoeagus curved, set with spines at the orifice.

Ovipositor flattened. Ostium plate with very small lobes; signum very small, with a few short points.

Genus 5. Peronea Curt. TYPE cristana, Fab.

Peronea cristana, Fab.

S. J. Capper. 4-2

Sacculus roundly cut off at half, gently emarginate beyond. Uncus indent, rounded; socii springing from low down, small, drooping. Ædoeagus stout, tip with rose thorn; cornuti 4-5.

Ostium plate with short, pointed lobes; signum stellate.

Peronea niveana, Fab. G. F. Whittle. 1-1 Valva rather short. Sacculus slightly arched, terminating in a jound knob of spines Cornuti two of equal medium length, in sockets, one of similar length below.

Ostium lobes acutely tapered; signum stellate.

Peronea umbrana, Hb. G. F. Whittle. 1-1 Sacculus emarginate at half. Socii long, slender, sharply pointed. Cornuti two large, and a group of five fine spines.

Ostium with projecting side pieces, lobes very large and wide. Signum stellate. 
Peronea maccana, $T r$.

1-1

Sacculus curved to a point before half, then emarginate in a gentle sweep to the anal angle. Socii drooping, widest at the apex. Ædœeagus with thorn. Cornuti four fine spines.

Ostium lobes very wide, elongately rounded. Signum small, scobinate.

Peronea ferrugana, $T r . \quad$ W. Mansbridge. 5-4 Saccuius almost straight, with small projection beyond half, terminating in a broad flattened end set with spines. Ædœagus curved; cornuti three spiniform.

Ostium simple, naked; lobes wide, curved.

Peronea boscana, Fab.

J. W. M. 2-2

Sacculus evenly curved. Socii hardly drooping, rather small. Cornuti a pair, and three rather short spines.

Ostium cleft; operculum lobed and spined; ostium lobes short pointed. Signum stellate.

\section{Peronea scabrana, Stph.}

Appears to be a variety of this species. We can find no difference in the genitalia.

Peronea permutana, Dup. $1-1$ Sacculus very broad, deeply emarginate beyond half. Cornuti in two parallel rows of three spines each.

Ostium lobes very long, curved, not pointed. Ductus bursæ with a well-formed lobe at either side. Signum stellate.

Peronea mixtana, $H b$. $1-1$ Sacculus angularly emarginate at half. Ædœagus with long spine at right-angles near orifice; cornuti three short. Ostium lobes almost squared at base. Signum stellate. 
Peronea shepherdana, Stph, J. $W: M .1-1$ Saccuius emarginate before and after half, forming a point. Anal plate heavily set with small spines. Cornuti four fine spines

Ostium with wide side pieces, lobes broad, rounded. Signum truncate, stellate.

Peronea aspersana, $H b$. $3-2$ We can see little difference between this and shepherdana.

Valva a little wider.

Ostium side pieces wider above, lobes narrower than shepherdana; ductus bursæ more definitely geniculate at the sides and longer.

Peronea holmiana, $L$. $1-1$ Valva widest at base; sacculus gently curved to anal angle. Socii drooping, set with long spines. Cornuti very numerous, probably about thirty spines.

Ostium lobes hardly extended. Signum scobinate.

Peronea lipsiana, Schiff. R. Adkin and J.W. M.

There are several points that suggest a break away from this genus.

Sacculus very broad, arched before half, edge rugose, terminating in a strong spined tip. Socii long, slender clavate. Cornuti many, very long, slender, about 14-15 spines.

Ostium lobes widely apart incurved. Bursa without signum.

\section{Peronea rufana, Schiff}

G. F. Whittle, J.W. Corder and J. W. M.

Valva wide; sacculus broad, very gently arched before half, €dge rugose, terminating in strong spined tip. Socii long, slender. Cornuti five fine spines.

Ostium and operculum minutely spined; lobes tapered, not widely apart. Signum scobinate. 
Peronea variegana, Schiff.

$9-3$

W. Mansbridge.

Sacculus broad, widely emarginate, edge rugose. Socii broad. Cornuti one rose thorn, eight to nine slender spines.

Ostium and operculum minutely spined; lobes wide, rounded. Signum scobinate.

\section{Peronea fissurana. Pierce and Metcalfe.}

נ. W. M. 2-2

Sacculus slightly arched. Ædœagus with strong branched spine before the orifice; cornuti one long, slender spine.

Ostium lobes short, tapered, pointed; ductus bursæ clothed with small black nodules. Signum stellate.

\section{Peronea reticulata, Strom. $\quad$ J. W. $M .2-1$}

Sacculus broad, emarginate before half, afterwards rounded to anal angle, which is pointed. Socii narrow. Edœagus geniculate. Cornuti three to five.

Ostium orifice minutely spined, lobes short, pointed, angular. Signum ovate, spined.

Peronea lorquiniana, $D u p . \quad J . W M .1-1$ The development here suggests a further removal from the genus

Sacculus broad, projecting lobe at half; afterwards emarginate. Socii specialised, long, erect, clothed with spines. Anal tube with narrow neck. Cornuti four spines.

Ostium naked, simple, operculum minutely spined; lobes curved, sharply pointed. Signum small, scobinate.

Genus 6. Rhacodia, $H b$. TYPE emargana, Fab.

Rhacodia emargana, Fab.

A development of Peroneidii.

Valva trigonate; costa thickened; valvula pointed. Sacculus extends upwards to and beyond the costa, then makes a complete hook, terminating in a head of spines. Uncus indent. Anal tube highly chitinised. Socii erect, 
and drooping, narrow above. Ædœagus with protruding counded plate (keel), orifice dentate without cornuti.

Ostium simple; lobes small, wide apart; ductus bursæ not thickened. Signum long - a few scattered points.

Genus 7. Oxigrapha, $H b$.

Oxigrapha literana, $L$.
TYPE literana, $L$.

S. J. Capper. 2-1

A development of Peroneidii closely allied to Rhacodia.

Valva trigonate; costa thickened; valvula bluntly pointed; sacculus extends upward to near the costa, then curves round in the form of a hook, terminating in a head of spines; on the outer margin of the sacculus is a projection at half. Socii ovate drooping. Æ¿dœagus with slightly curved hook at orifice; cornuti three spines.

Ostium naked, with minutely spined operculum; lobes long, incurved. Signum rounded, spined.

\section{Genus 8. Chrosis, Gn.}

Chrosis bifasciana, $H b$.

A development of Peroneidii.

Valva widest at base; costa not thickened; valvula long; sacculus lobed near base, extending and joining costa in a point; from the anal angle extend two projecting arms (finger and thumb). Uncus not cleft; socii drooping, curved inwardly. Cornuti three bulbed spines.

Ostium plate narrow, lobes hardly produced. Signum a scobinate crescent.

\section{PHALONIADII.}

The species included in this group divide into several wellmarked genera; they form connecting links with previous genera, especially with those of the group Cnephasidii. Further species would form interesting material for study and would probably be the means of throwing more light on certain genera now only indicated by isolated examples.

Valvæ generally broad. Uncus often well developed. Sacculus well developed. Cornuti strong. Female with large dentations covering the bursa. 


\section{Gends 1 . Sparganothis, $H b$. TYPE pilleriana, Schiff 4-1 Sparganothis pilleriana, Schiff.}

R. Adkin and J. W. M.

Somewhat nearly related to this group, but considerably removed; other species might help.

Valva simple; costa thickened; sacculus sharply pointed near the base; transtilla arched centrally, spined. Uncus very slender, curved; socii erect, clothed with scales, extended below in a pair of long arms set with bristles. Ed œeagus short. Cornuti deciduous, numerous, probably twenty.

Ovipositor flattened. Ostium small, rounded; signum a rugose band.

Gends 2. Hysterosia, Stph. TYPE inopiana, Haw. Valva simple, curved; costa thickened; sacculus broad, extended; transtilla strong, arched. Uncus long, slender; socii drooping. Adœagus stout, pointed.

Bursa generally in folds.

\section{Hysterosia inopiana, Jlaw.} R. Adkin, W. Purdey.

Sacculus short. Transtilla indent, spined. Socii long, pointed. Vesica of great size; cornutus a long, slightly curved spine.

Ovipositor partially retractile. Ostium eliptical. Bursa large, double, set with short spines, mostly in triplets.

\section{Hysterosia schreibersiana, Fröl $\quad 1-1$} G. F. Whittle.

Sacculus about half, not free. Transtilla strong, broad, pointed. Uncus curved; socii broad, rounded. Cornutus a long, slightly curved spine. Juxta extended centrally in an arm.

Ostium wide, with operculum; ductus bursæ very short; bursa thickened for more than half, edge irregularly çentate. 
Hysterosia amandana, $H-S \quad 1-1$

Sacculus short, terminating in serrate point; transtilla indent, spined. Uncus curved; socii lobed. ÆEdœagus stout, pointed, with spine near orifice. Cornuti a pair of strong spines.

Ovipositor flattened, angulate. Ostium very wide; bursa thickened, in folds.

Genus 3.

TYPE

maculosana, IIaw.

Valva simple; costa thickened; sacculus broad, tapered, ending before the valvula. Uncus stout, pointed; socii short. drooping; anal plate indent at the point. Æ\&dœagus with long orifice; cornuti short, very numerous, about 40 .

Ostium cleft; ductus bursæ irregularly asymmetrical, strong; bursa small, delicate, simple.

Genus 4. Clysia, $H b$.

TYPE ambiguella, $H b$.

Valva short; sacculus broad; transtilla produced in two arms; socii strongly chitinised. \#Edœagus short, stout; vesica very large, elaborately set with spines; cornutus long, slender, often broken during copulation.

Ovipositor flattened. Ductus bursæ short; bursa neavily spined.

Clysia angustana, $T r . \quad A . C$. Vine, J.W. M. 5-1 var thuliana. Vaughan, Adkin and Whittle. 1-1

We can see no difference in the genitalia of these two forms.

Sacculus merges into the valvula; transtilla arms partially fused together.

Bursa heavily spined.

Clysia ambiguella, $\mathrm{Hb}$.

S. J. Capper, R. Adkin.

Sacculus terminating in short spines; transtilla divided in two dentate arms; socii pointed.

Spines on bursa make a prominent central star. 
The following species have much in common but are divisable into several genera. The common characteristics are the divided saccus; the strong spine of the cornutus; the absence of uncus; the flying socii, that is where the socii terminate in a pair of chitinised, curved, slender hooks; the generally well-developed sacculus; the bursa much thickened often in folds and spined.

Genus 5.

TYPE

Valva long, narrow; sacculus rounded; transtilla produced in long, fused arm; uncus absent; socii weak, broad, curved inwardly. ÆEdœagus stout, orifice pointed; cornutus a stout spine.

Ovipositor narrow. Ductus bursæ short; bursa spined.

\section{affinitana, Dgls.}

F. G. Whittle A. E. Atmore.

Sacculus rounded, but produced outwards. Cornutus with small bulb.

Spines of bursa form a central star.

manniana, F.v.R.

=notulana Zell.

= udana female $G n$.

J. Gardner, A. E. Atmore.

Sacculus evenly rounded; transtilla arms longer than in affinitana. Cornutus strong, with large bulb.

Bursa irregularly spined.

Genus 6.

TYPE

atricapitana, Stph.J. W. M. 4-2 The development is too pronounced to be included in the other genera.

Valva pointed; sacculus broad, produced in a long brush of spines; transtilla a central arm, tip curved; socii reduced to two weakly chitinised lobes set with fine hairs. Edœagus geniculate; cornuti a band of short, thick spines. 
Ovipositor normal. Ostium bilobed in a strong, squamous plate; bursa delicate, scobinate.

Genus 7.

TYPE

nana, Haw.

The absence of the cornutus is rather unaccountable, stherwise it is closely related to this genus.

Valva long, narrow; sacculus produced in long point; transtilla fused, forming a long, slender hook; uncus developed, rather short; socii drooping. Edœagus geniculate, pointed; without cornutus.

Ovipositor normal. Ostium set in a bottle-shaped plate; ductus bursæ long, scobinate at junction with bursa; bursa heavily spined.

curvistrigana, Wilk. R. Adkin, J.W. M. 1-1 The absence of flying socii prevents inclusion in the following genus.

Valva narrow, widening to the sacculus; sacculus short, pointed, forming a wide emargination of the valvula; transtilla produced in fused, slightly dentate, arm. Socii mere pads. AEdœagus pointed at orifice; cornutus a bulbed spine.

Ovipositor normal. Ostium wide; bursa set with long spines, in a circle.

gilvicomana, Z. Sidney Webb's Col. 1-1 Valva narrow, widening to the sacculus; sacculus short, minutely pointed; socii distinct weak pads. Ædœagus with long, slender point at orifice; cornutus an aglutinated strong spine

Ovipositor normal. Ostium wide; bursa entirely covered with long spines. 
Genus 8. Phalonia, $\boldsymbol{H b}$.

TYPE aleella, Schulze.

The flying socii; the enormous anellus, and manica heavily spined, distinguish this genus.

Valva trigonate; transtilla large, broad, ending in two points. Ædœagus stout. Anellus very wide, cone-shaped; manica heavily spined; cornutus a slender spine.

Bursa spined.

Phalonia badiana, $H b$.

Sacculus hardly rounded; socii long.

Ostium in folds, expansive.

Phalonia cnicana, Dbd. F. G. Whittle. 1-1 Sacculus gently rounded; transtilla broader than badiana. Socii shorter than badiana

Folds of ostium not as expansive as badiana.

Phalonia dipoltella, $H b$.

F. G. Whittle, A. C. Vine, J. W. M.

Valva broad; sacculus squarely pointed; transtilla arm dentate. Ædœagus short, stout; cornutus a long spine.

Ostium small, leading to a huge bursis:

Phalonia rutilana, Haw. Lady Robinson. 1-1 Valva narrow; sacculus full, produced in curved point; transtilla a central arm. $\mathbb{E}$ doeagus stout; vesica scobinate. Cornutus very long spine.

Ostium wide; bursa long, narrow, in folds.

Phalonia aleella, Schulz.

R. Adkin, I. Gardner, A. E. Atmore.

Valva broad, emarginate on the outer edge; sacculus rounded near the base; transtilla broad, minutely dentate. Adœeagus stout, orifice heavily scobinate; cornuti a band of spines.

Ductus bursæ wide; bursa narrow, spined. 
Genus 9. Commophila, $H b$ TYPE aeneana, $H b$,
Commophila aeneana, $H b$.

Valva short, rounded; costa thickened; sacculus emarginate, tip produced beyond valvula; transtilla narrow, angulate, spined at the central junction. "Uncus absent, a mere point; socii well chitinised, forming two long. upright arms. Atdœeagus short, with curved hook at orifice; cornutus a strong spine.

Ovipositor hardened, specialised. Ostium small, squamous; ductus bursæ wide, leading into simple bursa.

Genus 10. Phtheochroa, Stph, type rugosana, $H b$.

Phtheochroa rugosana, $H b$. $1-1$

Valva curved; costa thickened; sacculus broad; transtilla centrally arched, spined. Uncus absent; socii drooping, rounded. Ædœeagus short, serrate at edge, with thin protruding plate (keel), base indent; cornutus strong spine. Tuxta produced.

Ostium wide, leading into partially thickened bursa, the thickening set with rounded protuberances (warts).

Genus 11. Pharmacis, Hb. Type sartana, $H b$.

= Euxanthis, $B b .(M y k)$. TYPE hamana, $L$.

We have been unable to examine the type of this genus, so have accepted Lord Walsingham's determination. The genus was created by Hubner for his new species sartana. We understand this species is somewhat indefinite and should much prefer that Hubner's name Euxanthis be retained until an opportunity arises for the type to be examined.

\section{Pharmacis hamana $L$.}

P. Richards, G. F. Whittle.

Valva complex; costa and valvula divided from the sacculus. Sacculus broad at its junction with the valvula, it is strongly modified in two dentate hooks; transtilla bilobed. Uncus 
absent; socii drooping; anal tube strongly chitinised. Adoeagus with hooked point at the orifice. Juxta produced in long upturned curved point.

Ovipositor narrow. Ostium very strong, cup-shaped, with operculum; ductus bursæ short; bursa clothed with long spines; signa a patch of pointed apple pips.

It is interesting to note, that in the parallel case of extreme fusion of the genitalia found in the Acidaliince (Geometrida) the signa in the female bursa are also composed of "pip"-like spines (apple pips).

Genus 12. Agapete, $H b$.

TYPE zoegana, $L$.

Agapete zoegana $L$.

Valva curved; sacculus very strong, pointed; transtilla arched, centrally spined. Uncus absent; socii a small arm at either side of the anal tube. Asdœagus curved, pointed, with long branch from one-third.

Ovipositor small, narrow. Ostium curiously constructed, the two sides overlap, forming a slit opening; ductus bursa just thickened; bursa delicate, simple.

Genus 13.

TYPE

alternana, Steph.

Valva very broad; costa thickened; sacculus extended nearly to costa, terminating in free tip set with scales; transtilla broad, bilobed, and set with short spines. Uncus absent; socii extending in two broad points. Edœagus pointed, branched, with broad rugose, antler-like shaft.

Ostium bilobed, in folds; bursa delicate, spined.

straminea, Haw. W. Mansbridge. 2-1 Valva broad, apex incurved; sacculus not thickened; transtilla broad, spined. Uncus absent; socii very weak. Adœeagus pointed. Cornutus a single curved spine.

Ovipositor long, narrow. Ostium weak; bursa delicate, Ecobinate. 
Genus 14. Aethes, Bilb. Type smeathmanniana, $F$. Valva wide, curved; transtilla strongly developed; socii flying. Ædoeagus very strong, cardinate, generally with large prolongation or shaft; cornutus usually absent.

Ostium elaborate; bursa spined

Aethes subbaumanniana, Wilk.

W. Purdey, J. W. M.

Transtilla a broad plate, deeply indent. Eldœagus curved, with a hooked spine at the orifice and a long, slender serrate shaft.

Ovipositor somewhat narrow. Ostium funnel shaped; ductus bursæ very narrow; bursa delicate, scobinate.

Aethes baumanniana, Schiff. $J . W . M . \quad 2-2$ Transtilla a broad dentate plate, deeply indent. AEdœagus gracefully curved, with two uneven points and a long, slender shaft.

Ostium funnel shaped, heavily set wich short spines at its junction with the very narrow ductus bursæ; bursa delicate, scobinate.

Aethes beatricella, Walsm. W. Purdey. 1-1 Sacculus thickened and slightly serrate; transtilla larga, strong, centrally produced, dentate. Eldœeagus short, curved, two-pronged (doubly pointed); vesica rugose.

Female very complicated and developed. Ovipositor normal. Ostium wide, asymmetrical, an opening leading into a blind sac; operculum strong, furnished on either side with a raised guide; bursa spined.

\section{Aethes francillonana, l'ab.}

P. Richards, E. F. Studd.

Sacculus deeply emarginate and produced in a squared arm; transtilla large and strong, deeply indent, forming a pair of pointed, dentate arms. Ædoeagus geniculate, with a long curved branch from the base of the orifice; vesica rugose.

Ostium elaborate; bursa spined. 
Aethes smeathmanniana, Fab.

P. Richards, F. G. Whittle, E. F. Studd.

Sacculus terminating in small curved plate; saccus divided, tach shaft long, bilobed. Edœeagus curved, double pointed; cornutus a strong spine.

Ostium strong; ductus bursæ thickened; bursa thickened and spined.

Aethes dilucidana, Stph.

J. Gardner, A. E. Atmore.

Sacculus rounded; transtilla short, broad, dentate. AEdœagus short, orifice pointed; vesica rugose; cornutus absent.

Ostium loosely folded; bursa spined.

Aethes maritimana, Gn. W. H. Harwood. 1-1 Sacculus obtusely pointed, with second point above; saccus terminates in a coarse point at the division; transtilla very long, rugose at the tip. AEdoagus curved, with long projecting blunt spine from orifice.

Ovipositor large. Ostium wide, with operculum, below which is a crescent shaped fold; ductus bursw spined at the junction of the bursa.

Aethes dubrisana, Curt.

= zephyrana, Myk, nec, $T r$.

Saccus terminating in a rounded end at the division; transtilla very long, not rugose at the tip.

Ostium wide, with ill-formed operculum, below which is a very small crescent shaped fold; ductus bursæ spined at the junction of the bursa.

Apart from the differences occasioned by its larger size, we can see but little difference between this species and maritimana. 
Genus 15.

TYPE

The great development of the unsus and general modification demands a separate genus.

Uncus long, articulated, apex indent; forming a complete covering and protection. Edœeagus prolonged at the orifice into a broad shaft; cornuti very long, springing from a common base. Ovipositor retractie. Bursa large, delicate, spined.

degreyana, $M c L$.

$1-1$

Valva long; costa irregularly emarginate; sacculus distinct, terminating in an obtuse point; transtilla strong, lobed at either side and centrally emitting a pair of blunt spines, some distance apart. Cornuti about 14-16.

Ostium bilobed.

ciliella, $\mathrm{Hb}$.

$2-1$

Valva broad, rounded, a roughly triangular plate at the anal angle; transtilla a broad plate, truncate at either side, centre emarginate, spined; cornuti about 12-20.

Ostium rather narrow, bilobed.

Genus 16.

TYPE

This very homogeneous genus has many distinctive characters.

Valva broad, strong. Saccus divided. Costa often separated, forming two upright arms spined at the apex; transtilla more or less developed. \#dœagus short, stumpy, with wide orifice set with a series of diminishing spines.

Ovipositor slightly retractile, narrow. Ostium in folds; bursa in folds.

implicitana, Wilk. J.W.M. 2-2

Valvula broad, point rounghly rounded; costa produced upward, spined at the tip; sacculus rounded; transtilla a small projection. Socii short upright arms. A£dœagus 
crifice prolonged in a long shaft, base bilobed; cornuti a large scobinate patch on the vesica.

Ostium thickened at either side.

\section{sabulicola, Wlsm.}

Valvula almost pointed; sacculus rounded; costa produced upward, spined at and below the tip; transtilla a mere projection. Socii short. Ædoeagus orifice prolonged in a strong, curled hook, base hardly bilobed; cornuti a large scobinate patch on the vesica.

Ostium very delicate.

subroseana, Haw.

F. G. Whittle, J. W. Corder.

Valvula slopes upward, almost pointed; sacculus not rounded; costa produced upward, spined at the truncated tip; transtilla centrally produced, armed with a few teeth. Socii very short. EDdoeagus orifice prolonged in a long, slender shaft; base rounded; cornuti a roughly scobinate patch on the vesica.

Ostium weak; ductus bursæ strongly thickened.

\section{rupicola, Curt.}

I. Gardner, F. G. Whittle, A. E. Atmore.

This species provides the key to the separated costa of the three preceding species. In this it returns to its normal position, fused to the valvula and spined at the tip, thus forming an emargination between the valva and sacculus; sacculus a broad plate; transtilla centrally produced, armed with many spines at the tip. Socii fairly short, drooping. Edoeagus orifice with short shaft; base rounded; cornuti a scobinate patch on the vesica.

Ostium more developed than preceding species. 
Genos 17. Cochylis, $T r$.

TYPE roseana, $H b$.

Costa fused to valvula, causing a deep emargination at its junction with the sacculus; transtilla a central curved arm. Uncus absent; socii mere scars set with hairs. AEdœagus geniculate, without cornuti.

Ovipositor more or less retractile. Ostium well developed; bursa weak, scobinate.

Cochylis pallidana, Zell. G. F. Whittle. 1-1 Valva deeply emarginate at its junction with the sacculus; sacculus large, long; transtilla narrow, with a couple of teeth at the apex. Edœagus geniculate pointed, set with small patch of spines.

Ovipositor partially retractile. Ostium in folds.

Cochylis roseana, Haw.

R. Adkin. 3-3

Valva deeply emarginate; sacculus serrate at its edge and in the emargination; transtilla a spatulate hook. Edœœagus sigmoid, pointed.

Ovipositor long, narrow, retractile. Ostium eliptical.

Cochylis flaviciliana, Wilk.

$1-1$

Valva deeply emarginate; sacculus wide, pointed; transtilla a dentate hook. Edoeagus narrow, slightly bulbed at centre.

Ovipositor long, retractile. Ostium bilobed.

Cochylis dubitana, $H b$.

J. W. M. 2-1

Valva not emarginate at the junction with the sacculus; sacculus deeply emarginate at the base, produced in a long spine; transtilla a wide, curved hook. Edœagus geniculate, crifice scobinate before the pointed tip.

Ovipositor not retractile. Ostium in folds; bursa ovate scobinate. 
Cochylis hybridella, Hb. F. G. Whittle. 2-2 Valva deeply emarginate; sacculus serrate, deeply and largely emarginate at its base, forming a long curved spine; transtilla a spoon shaped hook. Edoeagus curiously geniculated at right angles, curved and tapered to a point.

Ovipositor partially retractile. Ostium plate rounded in folds.

Genus 18.

TYPE

This genus has given infinite trouble in the past as regards the identity of the species. The genitalia now offer a certain amount of security; at the same time, it is important to note that the species run exceedingly close to each other. We give the full synonymy as a help.

Valva long, delicate; costa and sacculus very weak; transtilla a central arm curved, indent; saccus practically divided. Uncus absent; socii well developed and firm, the chief specific character. Edœeagus cardinate, sigmoid, pointed. Cornutus a single spine.

Ovipositor rather narrow. Ostium wide; bursa spined, with circular spined star

alismana, Rag.

= udana, (Myk) nec Gn.

Profile view of socii broad, slightly arched, and quickly reduced to a point set with fine hairs.

Ostium wide; ductus bursøe not narrow.

luridana, Greg. J. W. M. 2-1

= manniana, Myk, Barr, nec F. v.R.

Socii broad, very slightly arched, scarcely reduced to a rounded point set with long, stout hairs.

Ostium small, ductus bursæ long, very narrow. 
R. Adkın, J.W. M., A. Lofthouse.

Socii broad, gently arched and tapered to a point set with Ehort. stout hairs.

Ostium rather narrow; ductus bursæ long, narrow.

walsinghamana, Bankes. 3-1 =geyeriana,

Barr, Myk, nec Barr, Myk, nec $H-S$.

E. R. Bankes, J. H. Threlfall.

Socii broad, acutely arched, emarginate to a point set with fine, short bristles.

Ostium rather narrow; ductus bursæ very short; cstium leads almost directly into the bursa.

W. Purdey.

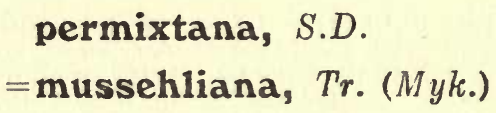

Socii broad, acutely arched, tapered to a point set with fine, short bristles.

Ostium small; ductus bursæ very narrow, long; the bursal circle of spines surrounded by a crinkled edge.

\section{OLETHREUTIDII.}

A small group that has been chosen to introduce a rather compact group. The valva is long, often set with strong spines at the termination of the sacculus; transtilla often fully developed. Uncus developed, but generally weak; socii large and drooping IEdoeagus cardinate, sometimes bearing one or more cornuti, often without.

The ovipositor is flattened, usually broad. Ostium strong with large minutely spined plate. Signum sometimes absent, generally one or two scobinate patches. 
Genos 1. Lobesia, $G n$. TYPE reliquana, $H b$.

The chief feature of this genus is the sharply divided sacculus, connecting it with Bracta. There is an interesting development on the first and second abdominal segment in the shape of a patch of specialised scales (? glands) which occurs in the two first genera.

Lobesia reliquana, $H b$. $2-1$

Valva narrow; sacculus hardly complete, beyond is a separated patch of spines. Uncus not produced, set with a few long, curved, broad, spatulate scales. EEdœeagus short, tapered.

Ostium wide, protected by a pear shaped plate. Signum large, scobinate at the junction of the bursa with its ductus.

Lobesia abscisana, $D b d$.

Lady Robinson, W. Purdey and J.W. M.

Valva narrow, widest before the apex; sacculus complete, head rounded, spined. Uncus not produced, set with a single row of spines along its edge. Edøeagus short, tapered.

Ovipositor not flattened. Ostium apparently inverted, a wide opening below through which passes the ductus bursæ; bursa scobinate.

Lobesia littoralis, W'wood. J. W. M. 1-1 Sacculus hardly complete, head spined. Uncus not produced, set with a single row of spines along its edge.

Ovipositor broad, flattened. Ostium wide; signum rounded, scobinate.

Lobesia euphorbiana, Fr.

Lady Robinson, R. Adkin, W. Purdey.

Valva not wider than the apex; sacculus cleft before the head, spined. Uncus not produced.

Ovipositor broad, flattened. Ostium narrow, strong, set with minute spines; bursa small, scobinate. 
Genus 2. Bracta, Steph. TYPE lanceolana, Hb.

A difficult genus to place, having only two species to consider. The valva and scobinate signum show a close connection with the previous genera, but the very highly developed uncus seems to suggest a further removal.

Bracta lanceolana, $H b$. W. Mansbridge. 10-3 Valva short, spined on the outer margin; sacculus angular, with deep depression set with fine hairs and containing a small patch of strong spines. Uncus produced, tapered, set at either side with a regular row of short blunt spines; socii rounded, drooping. Edœeagus short, curved, simple.

Ovipositor flattened. Ostium simple, with lip; signum round, scobinate.

Although specimens of this species vary considerably in size, there is no appreciable difference in size of the genitalia.

Bracta furfurana, Haw.

Valva short, thinly spined on the outer margin; sacculus rounded, with deep depression clothed with short, fine spines containing a patch of strong spines. Uncus produced, set at either side with a comb of short, blunt spines.

Ovipositor flattened Ostium small, simple. Signum rounded, scobinate.

Gends 3. Apotomis, $H b$. Type corticana, $H b$.

The apparently natural group of species usually included in the genus Argyroploce divides up into genera by the genitalia, not quite in accordance with the wing markings; and what have hitherto been considered close affinities in the genus Argyroploce are by no means so closely related and are found to divide into quite separate genera.

Valva long, almost clavate; sacculus extended in a round lobe set with strong spines. Uncus flattened, weakly set 
with fine spines; the position of this spining is an important adjunct to the differentiation of the several species. Socii large, drooping. Cornutus a single spine.

Ovipositor flattened. Ostium minutely spined. Ductus bursæ long, often coiled; signa two, rounded, scobinate.

Apotomis semifasciana, Haw.

J. W. M., A. Ford.

Sacculus produced, lobed, head set with short, strong spines. Transtilla a narrow band, minutely spined at either side. Uncus broad, rounded, a few fine spines at the tip and one pair on the dorsal side; socii broad, ovate; subscaphium drawn to a long point. Cornutus pointed, wider at the base.

Ostium minutely spined behind; ductus bursæ curled close to the ostium; signa two, scobinate.

Apotomis hartmanniana, $L$. A. Ford. 2-1 Uncus broad, rounded, set with a few scattered spines; several isolated ones on the dorsal side. Cornutus slender, long spine, base long and wider.

Ostium deeply cleft, heavily but minutely spined behind; ductus bursæ cylindrical for a considerable distance when it thickens and coils before reaching the bursa.

Apotomis corticana, Hb. A. Lofthouse. 3-3 Transtilla more heavily spined than betulatana. Uncus broad, rounded, set with a few scattered spines on either side; several isolated ones on the dorsal surface. Cornutus a short spine, base large.

Ostium deeply cleft, hardly spined; ductus bursæ thickened and coiled fairly close to ostium.

Apotomis betulaetana, Haw. $2-1$

We can see no difference between this and corticana except in the spining of the uncus, which in this species extends 
all round the tip, whereas in corticana it is confined to the sides. Transtilla less heavily spined than corticana.

Ostium stronger than corticana, spining heavier; ductus bursa corrugated, rugose coiled fairly close to ostium.

Apotomis sororculana, Zett. R. Adkin. 2-1 Uncus broad, rounded, evenly set with spines at either side, tip naked. Cornutus with base to spine.

Ostium almost round, thickly set with minute spines; ductus bursæ curly about centre, which is thickened and scobinate.

Apotomis sauciana, $H b$.

A. Lofthouse, R. Adkin.

Uncus broad, rounded, roughly set with spines. Cornutus small, with base to spine.

Ostium cleft, minutely spined behind; ductus bursæ curled and thickened near the bursa.

Apotomis grevillana, Curt. $3-1$ =staintoniana, Barr.

Lady Robinson, J. W. M.

Uncus broad, rounded, spined all round to base. Cornutus with base to spine (one specimen has a second slightly shorter spine).

Ostium thinly spined; Ductus bursæ rugose coiled and thickened near the bursa.

Apotomis capreana, $H b$. $1-1$

Valva strongly twisted (refuses to spread); sacculus not produced, angulate at termination, emitting a small patch of short spines. Uncus well spined with fine spines; cornutus with long base to spine.'

Ovipositor not flattened. Ostium cleft, thickly set with minute spines; ductus bursæ rugose coiled nearer to bursa. 
Genus 4. Olethreutes, $H b$. TYPE arcuella, $C l$.

The broad head of the valva disappears and is replaced by a long curved valva with almost parallel sides. Uncus sometimes bilobed. Cornuti absent.

The signa deepen to an extended point.

Olethreutes pruniana, $H b$. $3-1$

Valva curved, sides parallel spined above, becoming stronger as the sacculus is approached : from the outer edge a patch of specialised hairs in the form of a squared hook at right angles before reaching the point. Uncus narrow, with 5 or 6 strong spines at the tip. Edœagus cardinate, short.

Ovipositor flattened, narrow. Ostium deeply cleft with large spined encircling plate. Signa two, produced, scobinate.

Olethreutes ochroleucana, $\mathrm{Hb}$.

P. Richards.

Sacculus produced inwardly, terminating with a patch of spines; the outer margin has a large patch of specialised hairs with a curved hook before the point. Uncus bilobed.

Ostium rounded with spined encircling plate.

Olethreutes variegana, $H b$. $9-5$

Sacculus protrudes a small triangular plate, behind which is a small patch of fine minutely barbed spines. Uncus geniculate before the tip, which is considerably widened and bilobed.

Ostium cleft, with upright, spined, encircling plate.

Olethreutes salicella, $L$. A. Lofthouse. $\quad 1-1$ Valva long, strongly spined below, reaching to the sacculus. Uncus curved.

Ostium cleft, with upright spined encircling plate. 
Olethreutes arcuella, $\mathrm{Cl}$.

Valva long, angulated towards centre strong, spined below, throwing out two pedunculate spines from the margin. Uncus geniculate, bilobed. Cornuti about ten short, stout spines.

Ovipositor flattened. Ostium cup-shaped, minutely spined. Signum a squamous depression.

Olethreutes atropunctana, Zett. $1-1$ =dimidiana, Sodof.

G. T. Porritt.

Valva widest towards centre where it is angulated before a deep emargination at the succulus, a small patch of spines in the curve; sacculus extended, inwardly spined, and a further patch of spines centrally. Uncus long, slender; socii rounded. Adœeagus stout, with a single minute tooth towards apex.

Ostium cup-shaped, minutely spined. Signa two scobinate depressions.

Olethreutes penthinana, $G n$. $1-1$ = postremana, $Z$. E. F. Studd.

Valva long, strong spines below. Uncus short, broad, rounded; transtilla a pair of lobes set with strong spines.

Ostium deeply cleft, with squamous encircling plate; bursa squamous, without signum.

Genos 5. Eudemis, $H b$. Type profundana, Fab. This genus is evidently a remote branch from the preceding genera. The pilleate form of the signa, although derived from some species of the genus Olethreutes, is normally developed; the absence of uncus and the long drooping socii also suggest its transference to the Catoptria group. There is little doubt that in Britain there are many connecting links missing from this genus which might have shed light on its position 
Eudemis profundana, $F a b$.

F. G. Whittle, H. J. Turner.

Valva long, sides parallel, spined; outer margin set with even spines; sacculus squared, emitting long pointed hairs. Tegumen very long. Uncus not produced, stunted; socii very long, drooping, curved.

Ovipositor flattened, wide, angular. Ostium cupshaped with bilobed, minutely spined plate. Signa a pair, pilleate.

Eudemis pomedaxana Pierce and Metcalfe. 3-2 E. F. Studd.

Valva curved, spined: outer margin set with even spines; spining much stronger than profundana. Sacculus arched, emitting much shorter pointed hairs: Tegumen shorter than profundana; socii very long, drooping, very serrate on the outer edge.

Ovipositor flattened, rather narrow, not angulate. Ostium deeply cleft, squared, with bilobed spined plate; signa two, pilleate.

Genus 6. Argyroploce, $H b$. Type arbutella, $L$.

The long narrow valva returns, but the very distinct form of uncus, clavate on a long stalk (pedunculate) set at its upper edge with strong spines, seems to denote a distinct branch. In the female the squamous depression of the signum forms a pocket. Again the genitalia of some species run so closely alike that it becomes a question if they are really separate species.

It may be possible to get a more definite idea of this large group if a central form could be located. It is evident there are many branches all closely connected with a main trunk. 
Valva long, narrow; sacculus extended inwardly, set with strong spines. Uncus pedunculate, set with strong spines regularly arranged. AEdœagus short. Cornuti irregular, sometimes absent, a single spine or many spines.

Ovipositor usually narrow; ostium more or less minutely spined; signum a squamous depression in the form of a pocket or sac.

Argyroploce sellana, $H b$. . 4-1 R. Adkin, A. C. Vine.

Uncus with flattened head surmounted with two or three rows of spines; socii angular. Aløoagus stout; cornuti nine short stout in a line.

Ostium narrow, cleft, naked.

pullana is apparently a dwarf form of this species.

Argyroploce gentiana $H b . \quad J . W . M . \quad 1-1$ Valva narrow, apex abruptly curved; sacculus extended inwardly, set with many coarse spines. Uncus rounded, indent, set with four or five rows of spines; socii angulate. Ad ceagus short, stout, without cornuti.

Ostium ovately pointed, naked.

Argyroploce carbonana, $D b d$. $2-1$

=ustulana, Haw. (nec Hb.)

=fuligana, Bar. Meyk. (nec Hb.)

R. Adkin.

We can see no difference between this species and gentiana, except a big diversity in size.

Argyroploce oblongana, Haw.

$$
\text { = marginana, Haw. }
$$

Sacculus extended inwardly set with several coarse spines, mostly short, but a few at the apex longer. Uncus rounded, covered with numerous spines; socii acutely angulate. Adœagus short, without cornuti.

Ostium ovately pointed, naked; ductus bursæ thickened, set with a number of short spines. 
Argyroploce nigricostana, Haw

R. Adkin, J. W. M.

Valva narrow, evenly curved; sacculus extended inwardly, set with a single row of about six spines. Uncus with rounded head surmounted with a single row of spines; socii rounded. Ædœeagus short, stout, a long curved hook set below with three spines. Cornutus a single short spine.

Ovipositor not flattened. Ostium ovate, naked, a pair of thickened processes at its junction with the ductus bursæ.

Argyroploce fuligana, $H b$.

=carbonana, Barr. Myk.

The Hon. N. C. Rothschild, W. G. Sheldon.

We can see no difference between the genitalia of this species and nigricostana.

Argyroploce ericetana, W'wood.

$3-1$ R. Adkin, J. W. M.

Valva wide, sides parallel, curved; sacculus extended inwardly, set with a few stout spines; outer margin produced in a strong obtuse hook. Uncus with flattened ovate head set with three irregular rows of spines. Edœeagus pointed; cornuti five spines, one slightly larger.

Ovipositor flattened; ostium cup-form, naked, with flattened operculum.

\section{Argyroploce antiquana, $\mathrm{Hb}$.}

Valva narrow, curved; sacculus extended inwardly, set with small stout spines; towards the base is an elongate patch of slender spines, increasing in strength from the base. Uncus with narrow, flattened, ovate head with four to six central spines in a row, and one to three long drooping spines from either side. Cornuti about fourteen stout spines.

Ostium cup-form with operculum, naked; ductus bursæ thickened, set with minute small spines. 
Argyroploce branderiana, Female,L. =wahlbomiana, Male, $L$.

J. W. M.

Valva narrow, head clavate; sacculus lobed, set with a number of spines diminishing towards the base. Uncus geniculate lobed, set with fine spines. Edœagus short, serrate along its edge, scobinate behind.

Ovipositor very wide, flattened. Ostium rounded, minutely spined, plate cresent shaped, squamous.

This species seems closely connected with the genus Olethreutes.

Argyroploce mygindana, Schiff.

Valva wide; sacculus terminating in angular peduncle, emitting a strong spine covering a depression in the valva, set with long specialised hairs; editum produced, set with two or three spines. Uncus bilobed, clothed with curved spines. Ed Eøagus a simple cardinate tube.

Ostium small, plate large, minutely spined.

\section{Argyroploce arbutella, L. J. W. M. 1-1}

Valva narrow, spined at the junction of the sacculus; sacculus grotesquely extended sideways, terminating in a single spine. Uncus produced, small, heavily spined. Ædœagus long, terminating in a narrow point.

Ostium set in small minutely spined plate.

Genus 7. Phiaris, Hb. TYPE micana, $H b$.

The absence of the peculiar form of spined uncus necessitates a division from the preceding genus. This genus is by no means a natural one and is probably capable of subdivision and possibly of re-arranging to get closer affinities.

Valva usually rather narrow, often clavate; sacculus spined. Edoeagus with cornuti.

Ovipositor flattened; ostium plate usually minutely spined. Signum a single scobinate patch. 
Phiaris, urticana, $\mathrm{Hb}$.

Valva narrow, head clavate; sacculus extended in narrow lobe, spined; socii large, drooping; transtilla arched, set with long spines. Edœeagus with thickened introvertable extension having at its extremity a stout thorn.

Ostium slightly cleft, minutely spined.

Phiaris bifasciana, Haw.

A. E. Atmore, R. Adkin.

Valva narrow, head clavate; below, at its junction with the sacculus, are four or five strong straight spines; sacculus sinuate. Uncus weak. Cornuti about fifteen spines.

Ostium protruding, cup-form, naked; ductus bursæ sides irregularly rugose.

\section{Phiaris irriguana, $H-S$.}

Lady Robinson, R. Adkin.

Sacculus extended inwardly, heavily spined; on its outer edge is a long patch of coarse spines. Uncus rounded. Ad œeagus terminating in one or more spines; cornuti two rows of various sized spines.

Ostium cup-form, minutely spined.

This species is included as a var. of the following species by Standinger; the genitalia prove it to be a perfectly separate species.

Phiaris metalicana, $H b$.

=alternana, Wilk.

=daleana, Dbld List. F. C. Woodbridge.

Uncus arises from deeply indent sides of tegumen. Cornutus a single spine with broad base.

Ostium protruding, minutely spined, continued in a broad band at either side. 
Phiaris schultziana, Fab.

J. W. M. $\quad 3-1$

The spines on the valva diminish in size towards the apex. Edoeagus slightly dentate on its keel-like edge; cornuti absent.

Ostium protruded, attached to large oblong naked plate.

\section{Phiaris palustrana, $Z . \quad J$. Gardner. $\quad 2-1$}

The spines on the valva are largest towards the centre. Uncus indent. Æ\&dœagus not dentate; cornuti about seven short spines.

Ostium protruded, attached to naked, angular, oblong plate.

\section{Phiaris micana, $H b$.}

J. Gardner, A. E. Atmore.

The spines on the valva are largest towards the centre. Uncus rounded. Edœagus not indent; cornuti about ten short spines.

Ostium protruded, attached to naked, rectangular plate.

Genus 8. Celypa, Hb. TYPE striana; Schif.

Valva narrow; sacculus terminating in a patch of spines. On the ventral surface of the sacculus is a patch of long straight spines; these spines are specialised, they are of thin yellow transparent chitine set in a base and are probably very sensitive. Uncus weak, produced; socii drooping, often mere pads. AEdœagus very small, narrow, without cornuti.

Ovipositor flattened. Ostium minutely spined. Signum a rounded scobinate patch, sometimes entirely absent.

Celypa lacunana, Dup.

Rev. C. R. N. Burrows.

Valva narrow, at its junction with the sacculus is a small protruding lobe set along its edge with long spines; transtilla strong, plain. 
Ostium minutely spined is attached to a deeply bilobed narrow plate. Signum scobinate.

\section{Celypa rivulana, $S c$.}

Rev. C. R. N. Burrows.

Valva narrow, at its junction with the sacculus is a pad set with long spines; transtilla strong, minutely spined.

Ostium cleft, attached to minutely spined bilobed plate; bursa without signum.

Celypa latifascianum, Haw.

Valva narrow at the angle of the valva, and sacculus is a round patch of long straight spines; transtilla minutely spined.

Ostium small attached to a conical plate, spined behind; bursa without signum.

\section{Celypa doubledayana, Barr.}

W. G. Sheldon.

Valva narrow; below the angle of the valva and sacculus is a round patch of straight spines; transtilla plain.

Ostium narrow attached to a trilobed plate, minutely spined; signum absent.

Celypa woodiana, Barr.

The Honble. N. C. Rothschild, R. Adkin.

Valva narrow immediately below and adjoining the junction of the valva and sacculus is a patch of spines, whilst from the depression beneath spring a thick brush of fine pointed spines.

Ostium protruded cup-form, attached to a narrow incurved columnar plate minutely spined; signum absent. 
Celypa striana, Schiff.

R. Adkin, F. G. Whittle, J. W. M.

Valva narrow, immediately below the junction of the valva and sacculus are from eight to twelve strong spines, below this is the large patch of the specialsed spines. \&doeagus slender, long.

Ostium narrow, attached to a naked round plate minutely spined behind; signum rounded, scobinate.

Celypa purpurana, Haw.

We can see no difference between the genitalia of this species and striana in either male or female.

Standinger includes purpurana as a var. of rufana, Sc., from which it differs considerably.

Celypa cespitana, $H b$.

Valva narrow; below the junction of the valva and sacculus is a triangular flap, behind which a few stout spines project inwardly; from the outer edge of this flap spring a long row of the specialised spines.

Ostium minutely spined, attached to a crescent shaped plate extended at either side; signum rounded, scobinate.

Celypa rufana, $S c$.

Lady Robinson, H. J. Turner.

Valva narrow; sacculus angulate, at its point is a patch of spines; above, it is slightly curved and edged with long spines. Edœeagus long, slender.

Ostium attached to narrow, forked, minutely spined plate. Signum rounded scobinate. 


\section{ANCYLISIDII.}

A small but very compact group. The valvæ generally long; sacculus always more or less angulated; uncus bifurcate or single. Female with a pair of angulate plates on bursa, which form the signa.

Genus 1. Enarmonia, $H b$. TYPE woeberiana, Schif. This genus, represented by a single species, is connected by the male wit' the genus Lobesia in that it possesses glandular bodies on the second segment; on the other hand, the characteristic angulated blade of the signum seems to form a fitting link with the following genus Ancylis.

Enarmonia woeberiana, Schiff $1-1$

Valva rather short, slightly bilobed at the apex, the lower lobe emitting a strong spine; sacculus trigonate. Uncus weak, produced, clothed with hairs; socii large, rounded. Ėdœagus piriform.

Ovipositor flattened. Ostium narrow; signum an angular plate.

\section{Genus 2. Ancylis $H b$.}

TYPE laetana, $F$.

Valva long, narrow; sacculus angulate. Uncus bifurcate; socii drooping. Edœeagus cardinate, long; vesica thickly set with band of deciduous cornuti, piriform.

Ovipositor flattened. Signa two triangular thin plates emarginate below.

Ancylis mitterpacheriana, Schiff. $1-2$ Valva deeply emarginate; sacculus rectangular; uncus short.

Ostium cup-form, narrowed, sparsely spined.

Ancylis biarcuana Stph.

R. Adkin, A. E. Atmore, F. G. Whittle.

Sacculus with obtuse point. Uncus long, narrow.

Ostium with simple rounded lip. 
Ancylis inornatana, $H-S$.

Lady Robinson, John Gardner, F. G. Whittle.

Sacculus more rectangular than preceding species, otherwise very similar.

Ancylis diminutana, Haw. A. E. Atmore. 1-1 Sacculus less than a right angle, otherwise very similar to preceding species.

Ancylis comptana, Frül. J. W. M. 1-1 Sacculus acutely angled, point produced, otherwise similar to preceding species.

Ancylis derasana, $H b$.

A. E. Atmore, F. G. Whittle.

Valva outer margin gently curved, margins almost parallel; sacculus acutely pointed, point long.

Ostium with simple rounded lip; ductus bursæ short, bulbed.

Ancylis unguicella, L. F. G. Whittle. 3-1 Valva shortened, outer and inward margins strongly curved to a point.

Ductus bursæ long, thickened, sides converging.

Ancylis, uncana, $H b$.

Valva similar to preceding, but narrower and margins more nearly parallel: sacculus extended in angular flap.

Ostium slightly indent at centre.

Ancylis, obtusana, Haw.

Valva curved on the outer edge, slightly tapered; sacculus produced, deeply emarginate above.

Ostium with finely spined narrow lip. 
Ancylis laetana, $F a b$.

Valva gently curved, of even width; sacculus less than right angle, produced.

Ostium with eliptical plate, with a few minute spines at either side.

Ancylis. upupana, $T r$.

Lady Robinson, F. G. Whittle, W. Purdey.

Valva gently curved, tapered; sacculus emarginate, terminating in sharp point. Cornuti sharply barbed.

Ostium deeply indent, edge finely spined.

Genus 3. Anchylopera Stph. TYPE lundana F. The uncus is not produced. In other respects the genitalia is similar to Ancylis.

Anchylopera lundana $F a b$.

Valva curved on the outer margin, widest at the anal angle; sacculus angulate. Uncus not produced, bilobed.

Ostium with finely spined lip; ductus bursæ constricted.

Anchylopera myrtillana, $T r . \quad J . W . M . \quad 3-1$ Valva shortened, outer edge curved; sacculus angulate. Uncus not produced, two small points.

Ostium wide with large lip minutely spined.

Anchylopera paludana, Bar.

Lady Robinson.

Valva curved; slightly tapered; sacculus sharply angulate. Uncus not produced.

Ostium with wide minutely spined lip.

Anchylopera siculana, $H b$. Valva similar to preceding species, but broader; sacculus angulate, points drooping.

Ostium eliptical, with broad lip. 
Anchylopera achatana, Fab.

Valva curved on its onter edge; sacculus angulate, point rounded. Cornuti sigmoid.

Ostium wide, minutely spined, broad band, curved.

\section{EPIBLEMIDII.}

A large group in which the male genitalia are more or less uniform, but the pilleate form of the female signa is the chief characteristic.

Genus 1. Acroclita, $L d$. TYPe subsequana, $H-S$. = consequana, $H-S$.

The exact position of this species is difficult to locate. The valva and angulate sacculus denote an affinity with the preceding genera. The general formation of the valva, the long scales from the dorsal surface of the uncus, and the double signa all bring it into close affinity with the species included in the genus Zeiraphera; the nearest relatives being ratzeburghiana, rufimitrana and occultana, but the extraordinary development of the subuncal parts and the non-retractile ovipositor place it in a genus by itself.

Acroclita subsequana $H-S$.

Valva simple, rounded; sacculus with inwardly projecting lobe. Uncus roughly bilobed, thickly clothed with very long scales; arising centrally from either side of the uncus is a lobed plate set at its edge with long spines; below this at either side is a bifurcate projection, which may be a modified gnathos, the outer arm curved naked, the inner arm emitting two or three spines. Cornuti eight, deciduous.

Ovipositor flattened. Ostium simple, spined behind; signa two, pointed, scobinate.

Genos 2. Zeiraphera, $T r$. TYPE corticana $H b$. A small genus, closely connected with the preceding genus. 
Valva full, rounded. Uncus set with specialised scale hairs; socii long, drooping. Cornuti deciduous.

Ovipositor retractile. Signa pilleate.

\section{Zeiraphera diniana $G n$.}

A. Lofthouse.

occultana, Dgl.

Valva rounded, indent below. Uncus set with long lanceolate scales. Cornuti about fifty deciduous spines.

Ovipositor retractile, terminating at its base with a long emarginate plate from which spring the segmental rods; ductus bursæ constricted. The signum is an €xception, being single, pilleate.

Zeiraphera ratzeburgiana, Rts.

Valva geniculate towards centre, not indent. Uncus slightly produced, set behind with long, slender clavate scales; socii pointed drooping. Edœagus short, stout; cornuti about $\mathbf{j} 3$, deciduous.

Ovipositor retractile, terminating at the base with a long emarginate plate from which spring the rods.

Ostium narrow; ductus bursæ constricted near the ostium. Signa two, pointed, scobinate.

Zeiraphera rufimitrana $H-S$.

The Hon. C. N. Rothschild, J. W. M.

Valva rounded, gently curved, not indent. Uncus set with long clavate scales; socii curved, drooping. Cornuti about 21 , deciduous.

Ovipositor retractile, terminating in a long deeply emarginate plate. Ostium narrow. Signa two: one large, one small, scobinate.

Zeiraphera corticana, $\mathrm{Hb}$.

$2-4$

Valva long, slender, indent before and beyond the centre. Uncus hardly produced, set behind with long, fine hairs; socii curved, Jrooping. Cornuti about 15, deciduous. 
Ovipositor retractile, terminating with a slightly emarginate plate. Ostium narrow; ductus bursæ constructed near the ostium. Signa two pilleate, one broader than the others: scobinate.

Genus 3.

TYPE

Somewhat closely allied to the preceding genera, but the long uncus and semifloricomous ovipositor denote either a singular divergence or a separate genus.

trimaculana, Don.

J. W. M.

Valva curved, deeply indent at its junction with the sacculus. Uncus long, slender, double pointed; socii drooping. Ædœagus short; cornuti 15 long, broad, deciduous.

Ostium semifloricomous, set with long clavate spatulate spines, ending in a curved sharp point. Ostium simple, lined with minute spines inside; ductus bursæ thickened. Signa two, long, scobinate.

\section{Genus 4. Astatia, $\mathrm{Hb}$}

TYPE solandriana, Stph.

This genus may be distinguished by the long uncus doubly pointed at the tip, the large broad socii and the rather rronounced shape of the valvæ and sacculus, the latter kearing strong spines. The female has the two pilleate signa that seem to accompany this rounded form of valva.

The species run so closely together that they are only separable by comparison.

The cornuti vary in shape, some are figured.

Astatia ophthalmicana, $\mathrm{Hb}$.

Valva curved, kroader towards the apex; sacculus angulated, a small wide angular indent at the junction. Uncus long, strong, bipointed; socii large, angular. Ædœagus wide, pointed; cornuti long, about 22, deciduous.

Ovipositor wide, flattened; ostium narrow, simple; signa pilleate, wide, scobinate. 
Astatia solandriana $L$. W. Mansbridge. $60-20$ Valva curved, sides almost parallel, spining on outer margin considerably more than half; sacculus rounded, lower edge almost straight, emargination at the junction, wide, curved. Uncus long, bipointed, lower half set with spines, upper half naked; socii large, angular. Edœagus wide, short; cornuti about $36 \mathrm{long}$, wide before the end, which is angulated.

Ovipositor broad, flattened. Ostium narrow, set with acutely pointed spines. Signa pilleate, heads large.

Astatia sinuana, Hb. H. C. Hayuard. $\quad 20-10$ Valva curved, sides almost parallel, slightly indent; spining on outer margin hardly more than half; sacculus rounded, lower edge gently curved, emargination at the junction more abruptly curved than in solandriana. Uncus long, bipointed, almost entirely spined, only naked at the tip. Socii large, angular. Ædeeagus wide, short. Cornuti about 34 long, wide before the end, which is angulated.

Ovipositor broad, narrower below. Ostium narrow, set with obtusely pointed spines. Signa pilleate, heads large.

Astatia semifuscana, Stph. $2-1$ W. Mansbridge.

Valva curved wider above; sacculus curved, the patch of spines broadest above, emargination at the junction very shallow. Uncus strong, bipointed. socii angulated. Ed eeagus narrow; cornuti 6 to 8 .

Ovipositor wide, flattened. Ostium narrow. Signa pilleate, two short curved, scobinate below.

Astatia sordidana, $H b$. J. W. M. 3-1 Valva long, sides almost parallel; sacculus rounded, emargination at the junction very slight, hardly indicated. Uncus long, bipointed; socii angulated. Cornuti about 10 to 15 . 
Ovipositor flattened, broader above. Ostium narrow. Signa pilleate, two, short, broad, scobinate.

Astatia similana $H b$.

H. J. Turner.

Valva curved; sacculus rounded, the emargination at the junction narrow, rather deep. Uncus not tapered, bipointed; socii angulated. Fdneagus narrow. Cornuti about 16 , long.

Ovipositor flattened, wide above. Ostium narrow, with angulate plate. Signa pilleate, short, broad, scobinate.

\section{Genus 5. Panoplia, $\mathrm{Hb}$.}

TYPE cruciana $L$.

A genus closely allied to the preceding, as shewn by the bipointed uncus, the large arm-like socii, the similarly formed valvæ, and in the female the pair of long scobinate, pilleate signa.

Valvæ curved and merge into the sacculus, which bears a patch of spines on its rounded edge. Uncus stout, bifurcate; tegumen hooded. Cornuti many, deciduous.

Signa pilleate, scobinate.

Panoplia subocellana, Dup.

Valva short, wider above; sacculus spines few in two rows. Uncus cleft; socii pointed, curved. \#Edœagus stout; cornuti long, about 16 .

Ovipositor not flattened, wide below, densely and minutely spined. Ostium narrow; ductus bursæ thickened centrally. Signa long, narrow, scobinate.

Panoplia penkleriana, F.R. 'J. W. M. 1-1 Sacculus spines few. Uncus shallowly cleft; socii long, curved, tip rounded. Cornuti about 15, long.

Ovipositor slender. Ostium narrow; ductus bursw slightly thickened centrally. Signa small, short. 
Panoplia, signatana, $D g l s$.

J. H. Threlfall.

Valva curved, cucullus distinct, spines at anal angle. Uncus deeply cleft; socii long, tapered. Cornuti about 13-14.

Ovipositor flattened, not narrow. Ostium narrow, thickly and minutely spined behind. Ductus bursæ thickened. Signa very large, clavate.

Panoplia nemorivaga, Tgstr. $1-1$

Valva curved, with cucullus; sacculus right angled, spines strong at the rounded projection. Uncus cleft, sharply pointed; socii abruptly tapered, base strong, thickened. Cornuti about 10-11.

Ovipositor flattened, short, wide. Ostium set between lateral flaps. Signa large.

Panoplia immundana, F.R. J. W. $M . \quad 1-1$ Valva rounded; sacculus spines in a narrow irregular row. Uncus cleft, tips pointed; socii broad, spoon-shaped. Cornuti many.

Ovipositor flattened wide, densely and minutely spined. Ostium with thickened rim. Signa one very large, curved, the other smaller.

Panoplia mercuriana, $H b$. $1-1$

Valva with distinct cucullus, spines at anal angle; sacculus almost produced, clothed with spines. Uncus short, cleft; socii wide, tapered. Cornuti about 6 .

Ovipositor flattened, wide above. Ostium narrow below, at either side is a projecting teat. Signa tapered to a point.

Panoplia angustana, $\mathrm{Hb}$.

Lady Robinson, J. H. Threlfall.

Valva with distinct cucullus, outer edge slightly emarginate, spined from anal angle almost to apex; sacculus almost 
geniculate, terminating in a cavity set with spines. Uncus cleft; socii tapered to a point. Cornuti 20-22.

Ovipositor flattened, wider above. Ostium narrow, indication of teats; ductus bursæ slightly scobinate towards centre. Signa large, curved, scobinate.

Panoplia cruciana, $L$.

G. F. Whittle, E. F. Studd.

ab, obscura Tutt. J.W. Tutt. 2-0

Valva with distinct cucullus, outer edge gently curved, spined from anal angle almost to apex; sacculus gently curved, terminating in a cavity set with spines. Uncus cleft; socii tapered to a broad point Cornuti 13-16.

Ovipositor flattened wider above. Ostium narrow, teats strongly developed. Ductus bursæ thickened, scobinate towards centre. Signa large, curved, heavily scobinate.

These much disputed species are not greatly helped by the genitalia. Following the imagines, cruciana shows more strongly developed organs. As these differences appear constant, we have decided to keep them separate.

Genus 6. Proteopteryx, Wals. TYPE crenana $H b$.

Proteopteryx crenana, $H b$.

2-1

J. W Corder, J. W. M.

Although this species is greatly developed in the valvæ, we should not be disposed to make a separate genus for it.

Valva with distinct cucullus prolonged at the anal angle; the junction with the sacculus forms a wide emargination reducing the width of the valva; sacculus wide, angular, with patch of heavy spines. Uncus hooded, bipointed shallowly cleft; socii very wide, tapered. Cornuti many, about 25.

Ovipositor flattened, wider above. Ostium narrow, minutely spined. Signa large, curved, inner edge dentate. 
The principle feature of this genus is the hooded uncus, and the strong base of the socii. The species composing this and the following genera show connecting links with the genus Astatia.

Evetria nigricana $H-S$.

Valva wider above; sacculus spines in a patch; uncus short, hooded, cleft, tips broad; socii long, slender, tapered, with dense black base. Cornuti about 22 .

Ovipositor flattened, wider above. Ostium narrow, minutely spined. Signa large, scobinate.

Evetria rubiginosana $H-S$.

F. G. Whittle, R. Adkin.

Valva wide, below; sacculus spines a large patch towards base. Uncus wider above, emarginate; socii long, slender, tapered, base thickened. Cornuti about 16 .

Ovipositor very flattened, widest in centre, spines almost without tubercles. Ostium narrow, with deep internal collar. Signa long, curved, scobinate.

Evetria distinctana, Bent. M.S.S., Wilk. 1-1

$$
?=\text { proximana } H-S . \quad \text { A. E. Atmore. }
$$

If H-S. proximana, Vol. IV., pub. 1843-56, is the same species as Bentley's M.S.S. distinctana, first published by Wilkinson in 1859 , the name proximana appears to us to have priority, unless Haworth's fraternana, pub. 1803-1829, be this insect, in which case fraternana has still further priority. Stephen's description appears to agree, but Wood's figure 2112 does not seem recognisable.

Valva with indistinct cucullus, spines at the anal angle; sacculus spines in a patch; uncus comparatively long, deeply cleft, tips bluntly pointed; socii long, slender, slightly tapered, base thickened, drooping (drawn upright in figure); cornuti about 22 .

Ovipositor flattened. Ostium narrow, collar short. Signa large, scobinate. 
Evetria taedella, $\mathrm{Cl}$.

Valva narrow, angulated at sacculus; sacculus with patch of spines. Uncus short, cleft. Socii erect, tapered. Edœeagus short; cornuti many deciduous, eighth sternite emarginate.

Ovipositor flattened, wide. Ostium with collar; signa two, pilleate, scobinate.

Evetria demarniana, F.R. $1-1$

Valva not angulated, wider above; sacculus rounded, patch of strong spines. Uncus with shallow emargination. Cornuti about 18.

Ovipositor rather narrow, eighth tergite produced rounded. Ostium with collar. Signa long, curved.

Evetria bilunana, $H w$.

Valva wider above; sacculus spines in patch; socii erect, tapered with pad of short hairs at base.

Ovipisotor narrow. Ostium with strong collar. Signa stout.

Evetria tetraquetrana, $H w$.

Valva wider above, rounded; sacculus spines on raised protuberance.

Ovipositor flattened, eighth sternite produced, rounded. Ostium set at either side with a hollow cavity. Signa long.

Evetria ramella, $L$. $2-2$ Valva wider above, incurved, bluntly pointed at its junction with the costa. Cornuti about 18 .

Ovipositor long. Signa small.

Evetria cinerana, Haw. $2-1$ Valva deeply incurved along the costa before the pointed bead. Sacculus spines not continued without a break along 
the outer margin. Uncus short, cleft. Socii long, tapered, practically naked, one or two spines towards the tip. Cornuti about 18-20.

Ovipositor flattened. Ostium enclosed in angular pads thickly set with dark hairs. Signa long, narrow.

Evetria nisella, $C l$.

Valva deeply incurved before the pointed head. Sacculus spines continued without a break along the outer margin. Uncus widely cleft, not pointed. Socii long, tapered, practically naked; subscaphium strong. Cornuti very many, about 40-50.

Ovipositor flattened. Ostium simple, spined. Signa small, narrow.

Evetria nanana Tr. A. Lofthouse. $1-1$

Valva short; sacculus patch of spines represented by two or three rather stronger spines. Uncus short, cleft. Socii long, tapered, drooping. Cornuti many.

Ovipositor flattened. Ostium set at either side with an ovate plate from which protrude two or three short teeth near the base. Signa large.

Gends 8.

Neurasthenia, $W$ al and Drt. TYPE pygmaeana $H b$. The distinguishing feature of this small genus is the erect socii, closely allied if not a part of preceding genus.

Neurasthenia, subsequana $H-S$.

E. F. Studd.

Valva sinuous along the costa, two strong spines on the outer margin near the apex, widely emarginate and indent before the junction; sacculus spines in rounded patch. Uncus wide, very slightly cleft; socii large, erect, almost naked, a few spines below base very dense. Cornuti about 15. 
Ovipositor flattened, narrow. Ostium narrow. Signa short, pointed, roughly scobinate.

Neurasthenia pygmaeana. $H b$.

R. Adkin, F. G. Whittle, A. E. Atmore.

Valva incurved along costa emarginate on the outer edge, indent at the junction; sacculus spined with patch of strong spines. Uncus wide, cleft; socii large, erect, incurved, base dense. Cornutus deciduous, sharply angled before its attachment.

Ovipositor flattened, wide, short. Ostium narrow. Signum a short roughly scobinate spine.

Genus 9. Notocelia $\mathrm{Hb}$.

TYPE udmanniana, $L$. This genus is distinguished by the presence of two spines at the orifice of the Edœagus.

Valva with cucullus well defined; sacculus terminating interiorly in a point. Uncus atrophied, set more or less with hairs; socii drooping. AEdœeagus with two short spines at the orifice; cornuti numerous deciduous.

Ovipositor flattened. Signa two pilleate.

Notocelia udmanniana, $L$.

Valva with costal and outer margins almost parallel; cucullus extending slightly beyond outer margin. Socii of moderate length.

Ostium connected with a plate behind, which is widest above.

\section{Notocelia suffusana. $Z$.}

\section{=trimaculana, Haw.}

Valva less narrowed than rosccolana; costa strongly incurved to tip of cucullus. Socii of moderate length.

Ostium connected with a plate behind, the sides of which are parallel and which is surmounted with two hairy pads. 
Notocelia rosaecolana, $D b d$.

Valva very narrow before cucullus; cucullus drooping well below the outer margin. Tegumen very high; socii of great length.

Ostium connected with a plate, sides constricted.

Notocelia roborana, $T r$.

Valva with costal and outer margins almost parallel; cucullus not extending beyond outer margin. Socii wide, tapered.

Ostium set in a rounded plate, the upper part of which is straight.

Notocelia incarnatana, $\mathrm{Hb}$.

Valva gently protruded on outer margin before cucullus; cucullus not extending beyond outer margin. Socii short, narrow, quickly tapered.

Ostium set in oblong plate, the upper part of which is arched centrally.

Notocelia tetragonana, Stph.

Valva short; cucullus indent on its outer margin; sacculus has a rounded flap before the point. Socii short, incurved.

Ostium set in rounded plate, the upper part of which is curved.

Genus 10. Pardia, Gn. TYPe tripunctana Schif.

Pardia tripunctana, Schif.

Valva with costa arched near the base; outer margin indent considerably before cucullus; cucullus not distinctly divided. Socii short, almost rounded.

Ostium set in a heart shaped plate. Signa of unequal size.

Genus 1]. Eriopsela, $G n$. TYPE quadrana, $H b \quad 1-1$

\section{Eriopsela quadrana,}

Confined so far as British species are concerned to one species. 
Valva curved along the costa; deeply indent below the cucullus; socii pads flattened, not free. Edceagus pedunculate, coarsely scobinate, vesica with two long cornuti.

Ovipositor flattened. Ostium protruding cup-form; ductus bursæ wide, conate; signum pilleate.

Genus 12. Epiblema, $H b$.

TYPE foenella, $L$.

This genus shows roughly the same form of genitalia. The constancy of form of the valva makes description very difficult, if not impossible. Fortunately in many cases the wing parts are so distinct that it is not necessary to refer doubtfuls to the examination of the genitalia. We have tried to point out the distinguishing feature of each, but reference to the figure is almost imperative.

The absence of the two spines at the orifice of the Ed ceagus separates this group from the preceding one.

Valva with well marked cucullus. IJncus atrophied; socii drooping. EEdœagus on a peduncle, short, pointed; cornuti many, deciduous.

Ovipositor flattened, sometimes narrow. Ostium with a plate; signa a pair, pilleate.

The group pflugiana-circiana has been very carefully investigated. Specimens vary greatly, and the variation appears to extend to the genitalia. We can find nothing that enables us to separate the so-called species with any great confidence. We are also unable to say what Zeller's original circiana really represents. Barrett is apparently correct in staing that in pflugiana the female is smaller than the male, whereas in circiana, as generally accepted, the sexes are of the same size. There are further one or two dwarf forms, notably one from the Fens, which may prove to be distinct species. 
Epiblema pflugiana, Haw.

Valva sides almost parallel: sacculus terminating inwardly in obtuse point.

Ovipositor flattened, narrow, rods short, stout.

Epiblema circiana, $Z$.

Valva stumpier than preceding species.

Ovipositor rods long, slender.

Epiblema cnicicolana, Z. W. G. Sheldon. 2-1 Outer margin of valva curving gently to the cucullus; sacculus with a distinct obtuse point; socii long, narrow.

Ovipositor narrow, sides incurved. Ostium rounded, sides spined; ductus bursæ a short collar. Signa, one narrow, pointed; the other very wide.

Epiblema littoralana, Pierce and Metcalfe. 4-1 Outer margin of valva curving gently to the cucullus; sacculus with an indistinct obtuse point; cucullus rather longer and differently shaped from preceding species.

Ovipositor narrow, sides not incurved. Ostium more oval, spined above at either side. Signa, one narrow, pointed; the other very wide.

Epiblema trigeminana, Stph. $10-3$

A. Lofthouse.

Outer edge of valva with slight emargination before cucullus; cucullus long. Socii short, tapered.

Dark ostium edge continued across the plate.

Epiblema grandaevana, Z. J. E. Robson. 1-1 Sacculus has an additional obtuse spine or flap before the terminating one, which is small and ill defined. Socii wide, stumpy.

Ostium plate thickened only at its sides. 
Epiblema turbidana, $T r$.

Cucullus more curved than preceding species; sacculus has a pilleate spine before the terminating one, which is large, obtuse.

Ostium plate narrower, widely thickened at its edge.

Epiblema brunnichiana, Fröl. Sacculus angulate, emarginate before the cucullus; cucullus indent, apex turning outwards.

Ostium simple, constricted before ductus bursæ.

Epiblema foenella, $L$.

Sacculus angulate, emarginate before the cucullus; cucullus indent at the centre of its outer margin.

Ostium plate wider above.

GENds 13. Phaneta, Stph. TYPE pauperana, Dup. Closely connected with the preceding genus.

Valva somewhat narrower, rather stumpy, and cut off. Socii short.

Phaneta pauperana, Dup.

Valva curved along the costa; sacculus slightly emarginate before the cucullus; sacculus without terminating point. Socii short.

Ovipositor flattened, surrounded by a large collar, below which are two pairs of scobinate pads. Ostıum narrow.

Phaneta nigromaculana, $H w$.

Sacculus angulate; deeply emarginate before cucullus, no terminating point. Socii very short.

Ovipositor not flattened, specialised.

Phaneta maritima, Westd. = candidulana, Wlk.

The long soci separate this species from nigromaculana. 
Sacculus angulate, deeply emarginate before the cucullus. Socii long.

Ostium thickened behind in the form of a crescent.

Phaneta pupillana, $\mathrm{Cl}$. $1-1$ Cucullus trigonate, outer margin almost straight, deeply emarginate before the sacculus. Socii rather short.

Ostium in the form of a crescent, thickened behind.

Phaneta, amulana. Schlg. $\quad, \quad 2-1$ =tripoliana, Bar.

Costa curved; cucullus ovate; emargination wide and deep before the sacculus. Socii rather long.

Ostium with oblong thickening, indent below, behind.

Phaneta latiorana, H.S. = amulana, Myk.

Costa straighter than preceding species; eucullus more trigonate; emargination before the sacculus wider and not so deep. Uncus not so arched; socii shorter.

Ductus bursæ is shorter than in amulana.

Phaneta aspidiscana, $\mathrm{Hb}$. $2-1$ Costa almost straight, cucullus hardly wider than valva; emargination very wide, merely a curve from the sacculus. Socii very short.

Ostium with a pair of guiding spines internally.

Phaneta conterminana, H.-S.

Valva with sides almost parallel; sacculus slightly geniculate and hardly curved to the cucullus. Uncus deeply indent at the sides, making it appear almost round. Socii small.

Ovipositor narrow, rods very short, very wide above. Ostium plate short, wider abnve and arched. 
Genos 14. Catoptria, Gn. TyPe cana Haw.

The elongate cucullus appears to be the only distinguishing character to separate this group from the preceding one, in which the cucullus was markedly trigonate.

Catoptria cana $H w$.

Costa incurved; sacculus curved, not geniculate, curving gently to the cucullus. Socii rather long Cornuti long.

Ovipositor narrow, rods long. Ostium plate short, edges and base indent.

\section{Catoptria fulvana Stph.}

Costa slightly curved; sacculus curved, with a gentle bend to the cucullus Uncus hardly produced; socii rather long.

\section{Catoptria scopoliana, Haw.}

Costa well curved inwardly; cucullus long and narrow, drooping well below outer margin. Uncus slightly produced; socii rather long.

\section{Catoptria parvulana, Wilk.}

The genitalia are smaller than scopolianx, otherwise there is no perceptable difference in either sex.

Catoptria expallidana, Haw.

Costa curved; cucullus rounded above, slightly drooping below the outer margin. Uncus produced to a point; socii very tapered.

Ostium plate oblong, incurved on all four sides.

Gends 15. Eucosma, $H b$. TyPE circulana, $H b$. The extraordinary development of both male and female of the single species cacimaculana prevents us from including it under the preceding genus. We have examined the male of the Pennysylvanian species circulana and find that it is co-generic with this species. As circulana $H b$. is the type 
of Hubner's genus Eucosma, cacimaculana is the only British species representative of this genus.

The chief feature is the socketed spine at the termination of the valva.

Eucosma crecimaculana, $H b$.

Valva long, curved cygnate. ending in a strong socketed spine. Uncus atrophied, very slightly produced; socii curved. Edoeagus narrow: cornuti narrow, long, 14-16.

Ovipositor very narrow; ostium simple, with indent collar. Signa pilleate.

Genus 16.

TYPE

The long drooping socii and deciduous cornuti seem to connect up the following three species; but we are by no means certain they should be included in one genus as the signa vary in number.

resinana, $L . \quad$ R. Adkin. $\quad 1-1$

Valva with large cucullus, very deeply and widely emarginate; sacculus produced inwardly in an angular plate. Uncus articulated, but not produced, set with hairs; socii long, drooping. 'ÆEdœagus cardinate, short; cornuti deciduous, 5.

Ovipositor flattened, wide. Ostium with wide plate set at either side with three spines. Signa pilleate.

\section{posticana, Zett.}

Lady Robinson; H. W. Harwood.

Valva short, constricted before cucullus, forming a wide emargination below; sacculus produced to a point inwardly. Uncus rudimentary, set with hairs; socii long, drooping. Edoeagus cardınate; cornuti deciduous, 10.

Ovipositor flattened, wide. Ostium with heavy plate; ductus bursæ with thickened inside tube. Signum wide, scobinate. 


\section{turionana, $H b . \quad J . W . M$.}

Valva very similar to posticana, but much larger. Uncus with a tendency to become double pointed, rudimentary hairy; socii long, drooping, irregularly edged. Edœagus cardinate; cornuti deciduous, 13-15.

The female organs are very similar to posticana.

\section{EPHIPPIPHORIDII.}

A rather mixed group from a male genitalic point of view, but closely connected in the female, which has the two signa corniform. In the general plan of the male organs the valvæ are somewhat long and narrow, indent beyond the sacculus, often there are ninth segment coremata beautifully developed. The cornuti are broad, flattened and deciduous.

Genus 1. Rhopobota, Led.

TYPE naevana, $H b$.

Under the genus Steganoptycha, Stainton appears to have seen the close relationship of the members of this little genus, which subsequent writers have seen fit to divide. There is nothing in the genitalia of either male or female to place it here, nor in fact in any other existing group of British Tortrices, although the general characters are not such as to exclude it from this group. The highly developed iabides find parallel in some of the Geometrid genera. Unfortunately, the genitalia do not confirm the distinctiveness of two of the species geminana and naevana.

Rhopobota ustomaculana, Curt.

Valva long, curved, emarginate on the costa; sacculus terminating in a long point which reaches across the valva. Uncus absent; socii cygnate; labides long, tapered, hairy. Fdœagus short; cornuti deciduous, eight.

Ovipositor flattened. Ostium constricted behind; ductue bursæ short, thickened; bursa strongly thickened before the neck; signa two, small, curved, scobinate. 
Rhopobota naevana, $H b$.

W. Mansbridge.

Valva not curved, emarginate on costa and outer edge; sacculus weak, point not reaching across the valva. Uncus absent; socii in the form of an arum lily; labides long, clavate, hairy. Edœeagus short; cornuti many, about 20-24.

Ovipositor flattened. Ostium weak; ductus bursæ, short. thickened; bursa strongly thickened before the neck. Signa two, scobinate, one wider.

Rhopobota geminana, St. W. Mansbridge. 5-2 We can see no difference between this species and naevana.

Rhopobota fractifasciana, Haw. $1-1$ Valva curved, emarginate on the costa; sacculus angulate, not produced, deeply emarginate before cucullus. Uncus absent; socii delicate, a pair of long arms set with a few spines, labides long, rounded, curved. Edœagus short, dentate.

Ovipositor flattened. Ostium ovate; bursa thickened before the neck. Signa corniform, scobinate.

Rhopobota vacciniana, $Z$.

Valva with sides parallel, geniculate on costa near base; sacculus terminating in a point, centrally. Uncus absent; socii delicate, a pair of long arms finely spined; labides broad hairy. Edœagus short.

Ovipositor flattened. Ostium simple, ovate; bursa thickened before the neck; signa two corniform, scobinate. The genera containing the following species do not form a natural group. It is quite possible they are not closely connected and may prove to be off-shoots of other genera; at the same time, the strong apical spine of the valva, coupled with the form of the ostium place and the shape of the signa suggest a natural affinity to the preceding genera, so we include them here. 
Genus 2.

TYPE

simplana, F.R.

R. Adkin; W. Purdey.

Valva with cucullus; costa sharply arched near the base; saćculus extends along the outer margin and ends in a strong socketed spine (thorn). Uncus rudimentary and weakly chitinised, is produced in an arm which divides at the extremity, crutch-form. Socii not free, long hairy lobes. Cornuti many. Indications of coremata with comparatively short scales.

Ovipositor flattened. Ostium with oblong plate. Signa long, pointed, corniform.

Genus 3.

TYPE

albersana, $H b$.

A. E. Atmore.

The single signum and general formation of the male genitalia seem to denote that the species requires a more suitable position.

Valva long, terminating in a socketed spine, deeply emarginate at the anal angle; sacculus rounded. Uncus weak rounded, spatulate. Socii absent. Edœagus on a long peduncle, narrow; cornuti about 12, sigmoid.

Ovipositor flattened, angular. Ostium simple. Signum curved, not scobinate.

Genus 4. Spilonota, Stph. TYPE ocellana, $F \cdot 5-3$

\section{Spilonota ocellana, $F$.}

Valva long curved, cygnate, ending in a strong socketed spine Uncus absent. Socii almost erect, short, tapered. Edœeagus short; cornuti 7-9.

Ovipositor flattened. Ostium with elipitcal plate. Signa short pointed, scobinate. 
Spilonota lariciana, Hein. W. Mansbridge 5-: We can see no difference between this and the preceding species. At the same time, we would point out that in the first place the material is not very reliable; in the second place, the curious curvature of the valvæ make examination almost impossible. There appears to be some difference in the cucullus where it joins the costa; in some specimens it is emarginate, in others it is gently curved; the wing parts do not appear to hold true to this distinction. In the female, there is apparently a difference in the eliptical form of the ostium plate, but the difficulty of obtaining the same view prevents us from definitely declaring a distinction, and here again the wing parts do not coincide with this character. We prefer to leave them, as heretofore, separate species.

Genus 5. Gypsonoma, Myk. TYPe dealbana, Fröl. This rather compact genus is nearly allied to the preceding groups and connected through nanana. The uncus is lost and the socii much reduced. The spinin ${ }_{3}$ at the apex of the valva is a strong characteristic of the genus and brings Neurasthenia subsequana into close association with it, which is also borne out by the slightly different construction of the signa. The coremata of the ninth segment are generally well developed. The ostium of the female is elaborated.

\section{Gypsonoma aceriana Dup}

Valva squarely oblong, set at the apex with two or three sharp spines below the middle, and a single one at the anal angle Socii broad, rounded. AEdœeagus short, rounded, base bulbed; cornuti about 22. Coremata long scales.

Ovipositor flattened. Ostium with crescent shaped plate indented at either side before the ostium. Signa large 
Gypsonoma minutana, Hb. . J. W. M. $\quad 1-1$ Valva rounded, apex with patch of spines and a single spine at the anal angle. Socii broad, rounded. Ed woagus conical; cornuti many.

Ovipositor broad, flattened, without papillæ. Ostium lipped, with narrow plate. Signa pointed, corniform.

Gypsonoma dealbana, Fröl.

F. G. Whittle.

Valva rounded, set with spines at the apex, deeply emarginate below the anal angle, where there is a single spine; sacculus ill defined, forming a projecting spine centrally towards the costa. Socii broad, rounded. Cornuti many. Coremata composed of broad scales.

Ovipositor flattened. Ostium set at either side, with ఓ protruding plate bearing a round spiny prominence. Signa long pointed, corniform.

Gypsonoma neglectana Dup.

Valva rounded, set with a patch of spines at the apex, shallowly emarginate below the anal angle, which bears three spines. Socii broad, rounded. Cornuti many. Coremata long, curved scales.

Ovipositor broad, flattened, thickly set with tubercles and hairs, and darkly thickened. Ostium set at either side with an anguiar protruding plate clothed with fine spines. Signa long pointed, corniform.

Gypsonoma oppresana, $T r$.

Valva rounded set with a patch of spines at the apex, emarginate below the anal angle, which bears a single spine. A small projection near the costa towards the base; socii broad. rounded. Cornuti many. Coremata very long, slender scales.

Ovipositor flattened. Ostium set at either side with an irregular protruding plate, clothed with fine spines. Signa long, pointed, corniform. 
Genus 6. Rhyacionia $H b$. TYPE buoliana, Schif.

This genus is capable of being divided into several genera. It will be seen we have included citrana in it. The male, and signa of the female, suggest a close affinity, but it will be noticed that the ovipositor shows a strong difference, due to peculiarity of oviposition. A parallel case may be seen in the species incertana of the Cnephasia group. The way in which the species of this large group run into each other only to drift away and return requires many connecting links before a satisfactory classification becomes discernible. F N.P. differentiated the first and third species in the "Entomologists Record" for 1909, Vol XXI., p. 3, at the request of $\mathrm{E}$. R. Bankes and proved conclusively that there were two species.

Valva more or less cardinate, indent below the cucullus; Uncus atrophied; socii reduced to mere pads. Edœagus cardinate, irregular in formation, often dentate. Cornuti of such diversity as to suggest different genera.

Ovipositor (except in citrana) flactened, angular; cornuti very irregular, embracing other genera.

\section{Rhyacionia buoliana Schif.}

E. R. Bankes.

Valva stumpy, inwardly curved along the costa, emarginate below the cucullus on the outer margin. Uncus rudimentary, the tegumen forming two slight projections; socii round hairy pads. Ædøeagus cardinate, ending in obtuse point. Cornuti four, not deciduous.

Ovipositor flattened, angular. Ostium wide; ductus bursæ short. Bursa delicate, without signa.

Rhyacionia pinivorana, $7 /$.

W. Mansbridge; A. Lofthouse.

Valva stumpy; cucullus roundly pointed at the anal angle, 
emarginate below; sacculus terminating in a point. Uncus rudimentary, rounded, set at either side with a single hair; socii reduced to a pair of minute rounded pads, emitting four spines. Adocagus cardinate, stout, dentate above; cornuti two sets, not deciduous 17, deciduous 17.

Ovipositor flattened, wide. Ostium wide, cup-form; signa two, curred, slightly scobinate.

Rhyacionia pinicolana, $D b d$.

E. R. Bankes.

Valva narrow, deeply and widely emarginate below the cucullus on the outer margin. Uncus rudimentary, the tegumen forming a slight point spined at either side. ÆEdœeagus long: cardinate, ending in two obtuse points without cornuti.

Ovipositor flattened, angular. Ostium wide, set at either side with a rounded cavity; ductus bursæ long. thickened. Bursa with two pilleate signa, scobinate.

Rhyacionia retiferana, $W c k$. A. C. Vine. 1-1 A male and female supposed to be this species were sent for examination; these proved to be identical with pinivorana. We have not had an opportunity of examining genuine material.

Rhyacionia logaea, Drnt.

R. Adkin; J.W. M.

Valva narrow; cucullus pointed at the anal angle, emarginate below, the fold produced in an angular flap. Uncus rudimentary, pointed, and set with spines. AEdœagus short, narrow; cornuti 10-12, not deciduous.

Ovipositor flattened. Ostium narrow. Signa small, scobinate. 
Rhyacionia ? duplana, $H b$.

There appears to be no record of this species ever having been taken in Britain. We have not had an opportunity of examining the genitalia.

Rhyacionia citrana, $H b$.

Valva long; cucullus pointed at the anal angle, slightly emarginate below. Uncus rudimentary, pointed, and set with very long hairs; socii slightly drooping. Ædœeagus cardinate, ending in an obtuse point; cornuti deciduous, 9.

Ovipositor singularly developed, rerractile, pointed; below at either side of the opening is another point, minutely clothed with sharp spines. Ostium eliptical; signa pilleate of uneven size.

The formation of the ovipositor is a safe indication that the eggs are laid inside a slit made in the food. This may account for the fact that the larva is unknown. This ovipositor is unique among British Tortrices.

Rhyacionia microgrammana, Haw. J. W. M.

Valva narrow, cucullus pointed at the anal angle, slightly emarginate below. Uncus rudimentary, pointed, and set with two fine hairs at either side. Edœagus cardinate, very long, narrow, destitute of cornuti.

Ovipositor flattened narrow. Ostium constricted within leading to a blind sac from above which branches the bursa, which has a broad band of squamous teeth at the neck. Signa small, scobinate; corniform.

\section{Gendes 7. Cydia, $H b$, TyPe pomonella, $L$.}

The produced sacculus, fixed cornuti of male, and the dentate ductus bursæ of the female seem to denote a separate genus for the three following species. We would also note that the dornuti and signa tend to unite them to the species contained in the genera Pammene, etc. 
Cydia succedana, S.D.; Fröl.

=ulicitana, Haw.

Valva narrow, cucullus hardly pointed at anal angle, deeply emarginate below. Uncus rudimentary, naked. ÆEdœagus cardinate, branched towards the tip with a wide thorn-like spike; cornuti not deciduous, 12-14.

Ovipositor flattened. Ostium with narrow ring; signa long, slender, scobinate, corniform.

\section{Cydia coniferana, $R t z$. \\ A. Lofthouse. 1-1}

Valva long, cucullus rounded, emarginate; sacculus producing a long spike, below this a further emargination. Uncus rudimentary, set with a few fine hairs. Asdoeagus cardinate; cornuti not deciduous, 11.

Ovipositor flattened, wide. Ostium with narrow ring; ductus bursæ thickened, widened and set with two large teeth before the bursa; signa narrow, scobinate, corniform.

Cydia pomonella, $L$.

Valva long; cucullus rounded; sacculus producing a spike. Uncus rudimentary, pointed, naked. Edoeagus cardinate, with rounded plate towards apex; cornuti not deciduous, 7 .

Ovipositor flattened, wide. Ostium with ring; ductus bursæ thickened, widened below with dentate patch. Signa curved; scobinate corniform.

Genus 8.

TYPE.

The exereme narrowing of the valva before the cucullus, the absence of socii, the curiously fish-shaped deciduous cornuti and the long, simple signa. place the two following species in a separate genus. There are probably other non-British species which may throw more light on their relative position. 
sylvestrana, Curt.

Lady Robinson; Rev. W. Claxton.

Valva long, very narrow before the cucullus; sacculus forms a right angle, the apex of which is produced in an angular flap. Uncus rudimentary set with numerous hairs. Eddoeagus cardinate, short; cornuti deciduous, 5; very wide, spatulate, shaped like a fish.

Ovipositor flattened, 7th segment produced at either side forming a collar to the ostium. Ostium eliptical; ductus bursæ thickened; signa very long, tapered to a fine point, naked.

\section{purdeyi, Drnt.}

W. Purdey; J. W. M.

Sacculus forms a right angle, the apex of which is not produced in a flap. Edoeagus cardinate; cornuti 9, of which 4 are fixed, 5 deciduous, very wide, shaped like a fish.

Ovipositor flattened. 7th segment produced at either side into two blunt points Ostium ringed; ductus bursæ thickened; signa long, curved, tapered to a point, naked.

Gevus 9. Strophedra, Stph.

Strophedra nitidana, $F$.

TYPE flexana, $Z$.

Valva narrow; costa almost straight; cucullus ovate; sacculus very slightly indent before cucullus. Edœagus cylindrical; cornuti four or five rows of densely barbed spines, not deciduous.

Ostium gathered into an aglutinated point below; ductus bursa short; signa corniform curved.

Strophedra flexana, Z.

Costa incurved: cucullus more rounded. AEdceagus tapered; cornuti absent. Ostium gathered into an aglutinated point below the signa; corniform shorter than nitidana. 
Genus.10. Euspila Stph. TYPE compositella, $F$.

This and the following genus form a small group, closely allied. but divided by the spined tegumen.

Valva with distinct cucullus; indent before the sacculus. Tegumen spined with fine spines set in sockets. Edœeagus on peduncle; cornuti fixed and deciduous. The eighth segment developed ventrally in a flap from which extend the two sides laterally in the form of arms, terminating in a corematal pad irom which long filiform hairs protrude like a sweep's brush; the two sides are joined dorsally by an exceedingly delicate membrane, covering which is the final segmentail plate.

Ovipositor flattened. Ostium with pouch-like opening. Signa modified pilleate, or entirely absent. In an American species interstinctana, which is almost identical in wing markings with internana, the signa are also entirely absent.

Euspila caecana, Schlg.

Cucullus long, ovate. Spines on tegumen confined to the apex.

Ostium delicate; signa absent; Bursa round, with a round blind sac.

Euspila pallifrontella, $Z$.

Cucullus ovate: emargination wide, not deep; tegumental spines carried over a considerable portion of the tegumen.

Ostium cup-form, constricted before reck, set behind with stout scales, bursa with long, blind sac. Signa short hardly corniform.

Euspila compositella, $F$.

Cucullus more rounded; emargination deep; tegumental spines over a considerable portion of tegumen.

Ostium shorter than preceding species; bursa with blind sac; signa very wide. 
We have examined the form in which the dorsal blotch is not subdivided, making it appear as two narrow blotches. We can find no difference in the genitalia.

Euspila internana, $G n$.

Cucullus rounded; emargination deep, wider than precedin: species; tegumental spines cover a less area.

Ostium delicate, neck rather long: bursa with elongate, blind sac; signa wide, short, truncate.

GeNus 11. Ephippiphora,Dup. TYPE perlepidana, Haw The absence of the tegumental spines and the development of an additionas patch of broad scales from the corematal pad necessitate a division.

Ephippiphora scopariana, H-S.

Cucullus almos: trigonate; emargination very deep; tegumen naked. Edoeagus broad; cornuti two very long, fixed, as well as many deciduous. Coremata with broad scales.

Ostium with broad surround; ductus bursæ scobinate; bursa with long, narrow blind sac. Signa curved.

Ephippiphora perlepidana, Hw. 2-1 Cucullus narrow, rounded; emargination deep; tegumen naked. Edœeagus broad; cornuti three long fixed, as well as many deciduous. Coremata long, filjform.

Signa smaller than scopariana, corniform.

Genus 12. Grapholita, Tr. TYPE dorsana, $\boldsymbol{F}$.

This genus appears to run parallel to the two precedin genera. The connecting link seems to be the rather curious thickening of the ductus bursæ at the neck. Valva rather short; cucullus distinct; tegumen sometimes witb socketed spines Etdoeagus often tapered; cornuti deciduous, corematal pad emitting broad scales sometimes also filiform hairs.

Ovipositor flattened; ductus burse with a stron: thickening at the neck; signa corniform. 
Grapholita orobana, $T r$.

Cucullus rounded; tegumen with spines. Edoeagus constricted; cornuti many short deciduous, also three or four very fine acicular. Coremata filiform and broad scales.

Ostium with narrow collar with small projections at either side.

Grapholita dorsana, $F$.

Cucullus rounded; tegumen with spines. Adoeagus constricted scobinate; cornuti fine, long; coremata filiform and broad scales.

Ostium rectangular plate with small projections at either side.

Grapholita roseticolana, $Z$.

Cucullús roughly pointed above; sacculus extended in a blunt point; tegumen naked. AEdœeagus geniculate with a single cornutus deciduous. Coremata broad scales.

Ostium narrow, scobinate behind.

Grapholita ianthiana, $G n$. $3-2$

Cucullus very short; sacculus with rounded projection at 3/4; tegumen naked. Edœagus tapered, narrow, angularly widened at apex; cornutus one deciduous. Corepata broad scales

Ostium sharply angled to a point above.

Grapholita funebrana, $T r$.

Cucullus rounded, straight above; sacculus with angular projection at $7 / 8$; tegumen naked. Edœagus with upturned point at orifice; cornutus one, fish shape, deciduous. Coremata broarl scales.

Ostium a small circle with side pieces.

Grinds 13. Endopisa, Gn. TYPT nigricana, Stph. The absence of coremata separates this rarher closely allied species. Its exact position is uncertain. 
Endopisa nigricana, Stph.

Cucullus large. heavily spined inwardly; sacculus with angular projection before the cucullus; tegumen heavily scaled Adœeagus with angular apex; cornuti 5 long, fine, not deciduous.

Ovipositor flattened. Ductus bursæ with the strong thickening at the neck so prominent a character of the preceding genus. Signa corniform.

Gends 14. Cerata, Stph. TYPE servillana, Dup.

Closely allied, exact position uncertain.

\section{Cerata servillana, Dup.}

Cucullus rounded; emargination small. ÆEdœagus branched and dentate at $1 / 2$; cornuti 6 short, strong, not deciduous.

Ovipositor flattened. Ostium weak; ductus bursæ with strong thickening at the neck. Signa corniform.

Genus 15.

TYPE

Closely allied, exact position uncertain, probably branched from scopariana.

\section{strobilella, $L$.}

Cucullus rounded; emargination deep. સdœeagus obtusely pointed at apex; cornuti in two sets $3-4$, long, uneven length, 6-7 short, even.

Ovipositor retractile. Ductus bursæ with thickening at the neck, scobinate below; signa small, corniform.

Genus 16.

TYPE

Closely allied, exact position uncertain, probably a branch from Endopisa.

leguminana, $Z$. $\quad 1-1$

Costa almost straight; cucullus ovate; sacculus terminating in angular projection before the wide emargination; tegumental spines reduced to a minute pad set with three or 
four spines. Ædœagus tapered, cornutus probably one very fine, not deciduous.

Ostium plate not completely surrounding the ostium; ductus bursæ thickened at the neck; signa sma!l, corniform.

Gends 17.

TYPE

This closely allied species appears to be the connecting link to the following very compact genus. It possesses characters that crop up in various individuals of the group.

gemmiferana, $T r . \quad J . W . M .1-1$

Cucullus not distinct, spined; a patch of heavy spines at the junction of the sacculus; tegumen naked. Edocagus wide, pointed; cornuti one curved fixed, many deciduous.

Ostium rounded. Ductus bursæ thickened at the neck and scobinate. Signa corniform.

Genus 18. Pammene, Hb. Type trauniana, Schif. This genus may be distinguished from all others by the presence of a curious formation of scales at the base of the 6 th tergite - the basal edge of the 6th and 7th segments are strongly chitinised and form a sharply cut edge.

Valva with various modifications of cucullus; sacculus sometimes set with strong spines. Uncus atrophied, generally naked; tegumen often clothed with scales. Edœagus tapered; cornuti two sets deciduous and fixed.

Ovipositor flattened. Ostium generally in a cleft plate; ductus bursæ very short; bursa proportionately large; signa corniform, scobinate.

Pammene gallicana, $G n$.

=rufillana, Wilk.

Costa and inner margin inwardly curved; cucullus merged. Ædœagus sigmoid; cornuti 3, short, fixed.

Ostium cupform; ductus bursæ thickened at the neck. 
Pammene ochsenheimeriana, $Z$.

Cucullus wide with heavy spining at the junction with the sacculus; sacculus slightly produced, indent before cucullus. Edoeagus bottle shaped; cornutus one strong.

Ostium weak; ductus bursæ thickened at the neck.

Pammene splendidulana, $G n$. $1-1$ Cucullus ovate; emargination deep. Ædoeagus with projecting blind sac before orifice; cornuti about 7 strong, one deciduous.

Ostium widely ovate; ductus burso slightly thickened at the neck.

Pammene fimbriana, $H w$. , $1-1$ Cucullus very lerge, more than one half of the valva, pointed at the anal angle; sacculus with 4 or 5 exceptionally strong spines. Edœeagus with rounded projection before orifice; cornuti 10-12 fixed, 3 deciduous.

Ostium elongate; ductus bursæ thickened at the neck.

Pammene argyrana, $\mathrm{Hb}$.

Ćosta curved; cucullus elongate; sacculus with 12 exceptionally strong spines. Ædøeagus with rounded projection before orifice; cornuti several, about 12 fixed and 4 or 5 deciduous.

Ostium curved; ductus bursæ thickened at the neck.

Pammene costipunctana, Haw.

As costipunctana was originally a British species founded on a unique specimen, we describe an insect included in Dr. Mason's foreign types under this name, without suggesting that it is the same as Haworth's type.

Cucullus occupies nearly the whole valva; sacculus with two exceptionally strong spines. \&dœeagus bottle shaped; cornuti several fine, short fixed, 5 wide deciduous.

Ostium curved; ductus bursæ thickened. 
Pammene albuginana, Gn.

= obscurana, Wilk.

Cucullus occupies nearly the whole valva; sacculus without strong spines. Edœagus slightly bottle shaped; cornuti 3 fixed; 8 deciduous.

Segmental covering of ostium wrinkled; ostium curved; ductus bursæ thickened.

Pammene obscurana, Stph.

Cucullus elongate; emargination slight, wide. AEdœagus bottle shaped; cornuti several fine, fixed; 1 or 2 deciduous.

Ostium curved; ductus bursæ thickened.

Pammene aurana, $F$.

Valva with large patch of spines extending beyond the sacculus to the cucullus. Edœagus tapered: cornuti many, fine, fixed; one decidnous.

Ostium elongate, curved; ductus bursæ thickened.

Pammene rheediella, $C l$.

Cucullus angulated before junction with the snceulus. Adœagus tapered; cornuti 4 strong, fixed; 2 deciduous.

Ostium elongate, curved; ductus bursæ thickened.

Pammene trauniana, Schiff.

Cucullus obtusely angled before the sacculus; spines on sacculus in a pratch. Edoeagus tapered; cornuti several, fixed; 4 deciduous.

Ostium narrow, curved: clothed with mimute spines.

Pammene regiana, $Z$.

Cucullus rather rounded; sacculus evenly clothed with spines. Cornuti many, short, several deciduous.

Ostium wider than trauniana; the minute spining interspersed with long slender spines. 
Pammene spiniana, Dup.

Cucullus short, angulated at anal angle. 'Etdoagus tapered; cornuti many, fixed; 9 deciduous.

Ostium curved, ductus bursæ thickened with a few teeth at the base.

Pammene populana, $F$.

Cucullus hardly angulated at the anal angle. Ædœagus almost bottle shaped; cornuti many, fixed; 9-10 deciduous.

Sides of ostium project, forming a ridge with a stoop like opening.

Pammene juliana, Curt. 2-1 Cucullus elongate; emargination slight. સdœeagus bottle shaped; cornuti many, fine. fixed; about 21 deciduous.

Ostium curved; ductus bursæ slightly thickened.

\section{Pammene? nimbana, $\mathrm{H}-\mathrm{S}$. A. C. Vine.}

We have drawn a pair of specimens in the Vine collection purporting to be this species, the male genitalia appears to be identical with grossana $\mathrm{Hb}$. and the female with juliana Curt. In the absence of reliable material we express no opinion as to whether it is a good species or not

Gends 19.

TYPE

The strongly scaled tegumen, tapered Edœagus, the practical absence of cornuti in the male, the minute ostium and long ductus bursæ separate this genus from all the others.

Valva with indefinite cucullus; tegumen thickly clothed with strong scales. Edœeagus tapered, sometimes bottle shaped.

Ostium very small; ductus bursæ long, simple; signa short, corniform. 
Valva with large patch of spines at the angle of the sacculus, between this and the cucullus naked. Edœeagus narrow, tapered; cornutus one.

Ostium plate constricted behind minutely spined and interposed with long hairs.

germarana, $H b$.

Cucullus with strong spines at the junction with the sacculus; emargination curved with small round patch of 6-7 fine spines. Ædoeagus tapered before the orifice; cornuti one slender, fixed, 3 deciduous.

Ostium curved, only spined centrally behind.

splendana, $H b$.

Cucullus defined. Edœagus bottle shaped, dentate where it narrows.

Ostium minutely spined and interposed with many long, fine hairs; bursa with small scobinate patch at the neck.

grossana, $H w$.

Valva with raised fold between cucullus and sacculus. Ædoeagus bottle shaped without dentations.

Ovipositor specialised, set with strong socketed spines. Ostium set with broad scales; ductus bursæ narrow.

Genus 20. Laspeyresia TyPE $H b$. corollana, $H b$. $1-1$ N. C. Rothschild.

The absence of the eighth segment development separates this genus from the following to which it is otherwise closely allied.

Laspeyresia corollana, $\mathrm{Hb}$.

Valva with distinct cucullus, indent before the sacculus. Spines on tegumen confined to the uncus. Aldoagus with dentate ridge centrally. Cornuti a pair and five short, stout spines. 
Ovipositor flattened; ostium with deep, thickened collar; ductus bursæ dentate Signa corniform.

Genus 21.

TYPE

cosmorphorana, Tr. $\quad 1-1$

Valva simple; sacculus set with long spines; tegumen naked. Ædoeagus short, stout; cornuti three sets; one set of four long, the other two of six short.

Ovipositor flattened. Ostium with short dentate ductus bursæ; signa corniform.

Genus 22.

TYPE

hypericana, $\mathrm{Hb}$.

Valva simpie; sacculus with round patch of clavate hairs; tegumen naked. EEdœeagus without cornuti, a projecting flap at apex.

Ovipositor flattened. Ostium weak; ductus bursæ very narrow, duct long; signa widely corniform.

Genus 23. Selania, Stph. TYPE leplastriana, Curt. 1-1 Selania leplastriana, Curt

Valva wider at cucullus, which has a row of spines terminating in one very strong at the anal angle, the valva clothed with large dark scales; tegumen naked. AEdœagus geniculate; cornuti two long, strong fixed spines and a large number, probably one hundred, deciduous spines.

Ovipositor flattened. Ostium wide; ductus bursæ constricted, opening into a large, thickly chitinised dentate bulb at the neck of the bursa; signa corniform.

\section{LIPOPTYCHIDI.}

Valva cardinate; cucullus well developed. Uncus atrophied, naked; socii absent. Edoeagus cardinate; cornuti deciduous. Signa one curved, scobinate spine.

Genos 1. Hemimene, $H b$. TYPE petiverella, $L$.

The Dichroramphas are a fairly conipact group and are divided from the Lipoptycha by the absence of the large 
spatulate anellus lobes, which are present in that genus; otherwise the genitalia show strong connecting links.

Valva more or less cardinate; cucullus large; sacculus not produced. Uncus atrophied, naked; socii absent. Esdœagus cardinate on a peduncle; cornuti many, deciduous.

Ovipositor usually flattened. Ductus bursæ thickened above, tubular. Signa usually one long, curved; scobinate spine

Hemimene petiverella, $L$. J. W. M $\quad 3-3$ Costa deeply emarginate before the cucullus, giving the whole valva the appearance of being turned round at the extremity. Cucullus twice pointed, at the anal angle and also at the start of the oblong emargination before the sacculus. Edœagus spiral; cornuti about 25 .

Ovipositor narrow, not flattened. Ostium rounded, supported by a pair of long, strong rods; ductus burse curled, neck not truncate.

Hemimene alpinana, $T r$.

$$
\text { = flavidorsana, Knaggs. }
$$

Cucullus divided from valva, crescent form. Aidœagus spiral at the tip; cornuti about 20.

Ovipositor flattened. Ostium rounded, supported by a pair of short, stout rods; ductus bursæ curved to left, neck truncate.

Hemimene questionana, $Z$.

= politana, $H b$.

Costa angulate before cucullus; cucullus once pointed before anal angle. Edoeagus curved ending in a long curled projection; cornuti about 25.

Ovipositor flattened. Ostium rounded; ductus bursæ long, straight, curled before the bursa. 
Hemimene plumbagana, $T r$.

Costa deeply emarginate before the cucullus; cuculus ovate, extremity to a point. Addoagus short, tip rounded; cornuti many.

Ovipositor flattened, rather narrow. Ostium with a lip set in a large, thick plate; ductus bursæ narrow, short.

Hemimene consortana, Stph. J. W. M. 3-1 Costa gently curved to cucullus; cucullus almost squared before the outer emargination before the sacculus. Ædoeagus sigmoid, ending in two or three dentations; cornuti 4-6.

Ovipositor flattened. Ostium deeply cleft, supported by strong arms; ductus bursæ short, edged with balck nodules.

Hemimene simpliciana, $H w . \quad J . W . M . \quad 1-1$ Valva narrows considerably before the cucullus, which is evenly expanded on the costal and outer margins. \&edoeagus short, cornuti very numerous.

Ovipositor flattened. Ostium rounded, supported by a pair of very short rods; ductus bursæ long, campanulate, edged with black nodules.

Hemimene alpestrana, $H-S . A . C$. Vine. $1-3$ Valva slightly emarginate before cucullus, a deep, oval emargination before the sacculus. Ædœeagus narrow, widened and dentate at the apex; cornuti about 22 .

Ovipositor flattened. Ostium eliptical; ductus l.ursæ long, conical.

Hemimene tanaceti, Stt.

$$
\text { = herbosana, Bar. J. W.M. }
$$

Valva short; costa curved to cucullus; an emargination before the sacculus; cucullus folded forming a flap. FEdœeagus very wide, spiral; cornuti about 25 in two rows.

Ovipositor flattened. Ostium rounded, supported by heavy rods; ductus bursæ bulhed. Signa two, one much smaller. 
Hemimene acuminitana, $Z$. J. W. M. 1-1

Costa almost straight; cucullus bluntly pointed before the ovate emargination. Edoeagus short, a tooth at the apex; cornuti about 9 .

Ovipositor flattened. Ostium rounded, thickened all round and supported by a pair of stout rods; ductus bursæ, conical to a point.

Hemimene sequana, $H b$.

Costa gently curved to cucullus; cucullus rounded, deeply cleft before the sacculus. Æđdœagus long, very curved; curled to a point at the apex; cornuti 12-19.

Ovipositor narrow. Ostium rounded; ductus bursæ long, spiral.

Hemimene senectana, Gn. J. W. M. 1-1 Valva stumpy, gently incurved on both costal and outer margins before the rounded cucullus. Edœagus long, curved, pointed; cornuti about 11.

Ovipositor flattened. Ostium cup-form; ductus bursæ long, sides parallel, curved to left.

GeNus 2. Lipoptycha, Ld. TYPE burgnionana, Dup.

So far we have differentiated four species, three of which have already been described and named. The males differ but little, but the females show much stronger difference. The wing markings of all are very similar. We have not examined the :ype.

Valva constricted before the cucullus. Uncus atrophied, practically naked. A\&dœagus short on peduncle; cornuti deciduous; anellus lobes large, ovate, spatulate, scobinate.

Ovipositor flattened. Ostium cup-form; ductus bursæ tubular, thickened above; signum long, curved, scobinate. 
Lipoptycha plumbana, Sc.

Valva comparatively narrow; emargination before sacculus very narrow. Anellus lobes weakly scobinate.

Ostium funnel shaped, uneven at the sides, with a central flap which appears to divide the tube into two halves. Signum curved, scobinate.

Lipoptycha torrana, n.s. Pierse \& Metcalfe.

J. W. M. from Torquay.

Valva wider than plumbana; emargination before sacculus wider than plumbana. Uncus set with two small spines. Anellus lobes very weakly scobinate.

Ostium set in thick chitinous ring, arched behind bearing at each side three spines. Ductus bursæ long, cylindrical. Signum curved, scobinate.

Lipoptycha aeratana, Pierce \& Metcalfe 4-1 J. H. Threlfall, Col., F. G. Whittle.

Valva as wide as preceding species, but much more constricted; emargination before sacculus wide and round; cucullus folded, forming a flap. Anellus lobes large and very atrongly scobinate.

Ostium set in a thick chitinised ring, not arched behind: ductus bursæ much wider than preceding species. Signum curved, scobinate.

Lipoptycha saturnana, $G n$. J. W. M. $\quad 3-2$ Valva large, wide; emargination before sacculus wide and rounded; cucuilus more ovate, not folded. Anellus lobes large but weakly scobinate.

Ostium set in thick chitinous ring slightly raised behind bearing at each side a single spine; ductus bursæ wide. Signum long, curved, scobinate. 


\section{GLOSSARY.}

The full glossary is given in the volume of the Geometridæ. It has been expedient to use the following additional terms :-

Campanulate: bell-shaped. J.B.S.

Corniform: in the form of a cow's horn. J.B.S

Deciduous: shed, used in conjunction with the cornuti.

J.B.S

Fusiform: spindle shaped, tapered gradually to each end

J.B.S

Pilleate: in the form of a Greek cap P.

Spiniform: in the form or shape of a spine. J.B.S. 


\section{LIST OF SUBSCRIBERS.}

Whose support the Authors gratefully acknowledge.

Adkin, Robert, F.E.S. (2 Copies).

Bergstedi, Dr. J. H., Stockholm.

Blackmore, E. H., F.E.S.

Brooklyn Institute of Arts and Sciences, New York (3 Vols.:

Buckley, W. (3 Vols.)

Burrows, Rev. C. R. N., F.E.S.

Busck, Dr. Augustus.

Cairo Ministry of Agriculture.

Cardiff Public Libraries (3 Vols.)

Cawthron Trust, Nelson, N.Z. (3 Vols.)

Corder, James, W. (3 Vols.)

Cotton, John, M.R.C.S.

Craske, E. S. (3 Vols.)

Curtis, W. Parkinson, F.E.S.

Deighton, Bell \& Co., Ltd. (3 Copies, 7 Vols.)

Delhanty, J. E. (3 Vols.)

Dulau \& Co., Ltd. (3 Vols.)

Edlesten, H. Mc. D., F.E.S.

Entomological Society of London.

Fernald, Prof. H. T. (3 Vols.)

Fletcher, Miss Isabel.

Fletcher, W. H. B., M.A., F.E.S.

Fletcher, T. Bainbrige, R.N., F.E.S.

Fleming, G.

Friedlander, R. \& Co., Berlin.

Garnett, Theodore, M.A.

Haines, F. H., M.R.C.P., L.R.C.P., D.P.H.

Hallett, H. M., F.E.S.

Hayward, A. R. (3 Vols.)

Heinrich, Carl.

Hiles. H. E. 
Hobson, A. D. (3 Vols.)

Hooper, Dr. D. (2 Vols.)

Horne, Arthur, F.E.S.

Imperial Entomogist, Pusa. India.

Jackson, W. Hatchett, M.A., D.Sc.

John, Evan, F.E.S. (3 Vols.)

Jones F. M., Delaware, U.S.A.

Leveti, The Rev. Thomas Princep, F.E.S. (2 Copies)

Lofthouse, T. Ashton, F.F.S.

Low's Export

Manchester Museum, per Dr. W. M. Tattersall.

Marumo, Nobukatsn, F.E.S., Tokyo, Japian (2 Vols.)

Mansbridge, William, F.E.S.

McGill University, Montreal.

Mera, Arthur W. (3 Vols.)

Melvill, J. Cosmo, D.Sc., M.A., F.L.S., F.E.S.

Meyrick, Edward, B.A., F.R.S., F.Z.S., F.E.S

Midgley, Thomas.

Mitchell Library, Glasgow.

National Museum of Wales, Cardiff.

Newstead, Professor R., M.Sc., A.L.S., Hon. F.R.H.S., F.E.S., F.R.S.

Nicholson, Charles, F.E.S.

Norton, F. (3 Vols.)

Oxford University Museum Library, Hope Dept., per Prof. Edwarả B. Poulton, D.Sc., F.E.S., \&c.

Pickard-Cambridge, A. W. (3 Vols.)

Pierce, Miss Elizabeth.

Prout. Louis, B., F.E.S.

Proby, Colonel D. J.

Quaritch, Bernard.

Rimmer, Charles P.

Rothschild, The Hon. N. Charles, M.A., F.T.S., F.Z.S.,

F.T.S. (2 Copies, 3 Vols.)

Routledge, George Bell, F.E.S. 
Scott, Dr. Hugh, M.A., F.E.S.

Sheldon, W. G., F.E.S., F.Z.S.

Smart, H. Douglas, M.D., B.S., F.E.S. (3 Vols.)

Smith, S. Gordon, F.L.S., F.E.S.

Stott, C. E., F.E.S.

Trinity College Library, Dublin, per Alfred de Burgh.

Tonge, Alfred E., F.E.S.

Turati, Count Emilio, F.E.S.

Turner, Henry Jerome, F.E.S. (2 Copies)

Tyerman, W. A.

Watkins \& Doncaster. (2 Copies)

Waters, E. G. R. (3 Vols.)

Webster, William, M.R.S.A.I.

Whittaker, Oscar, F.E.S.

White, Henry T.

Williams \& Norgate.

Wood. H. Worsley, F.E.S. 

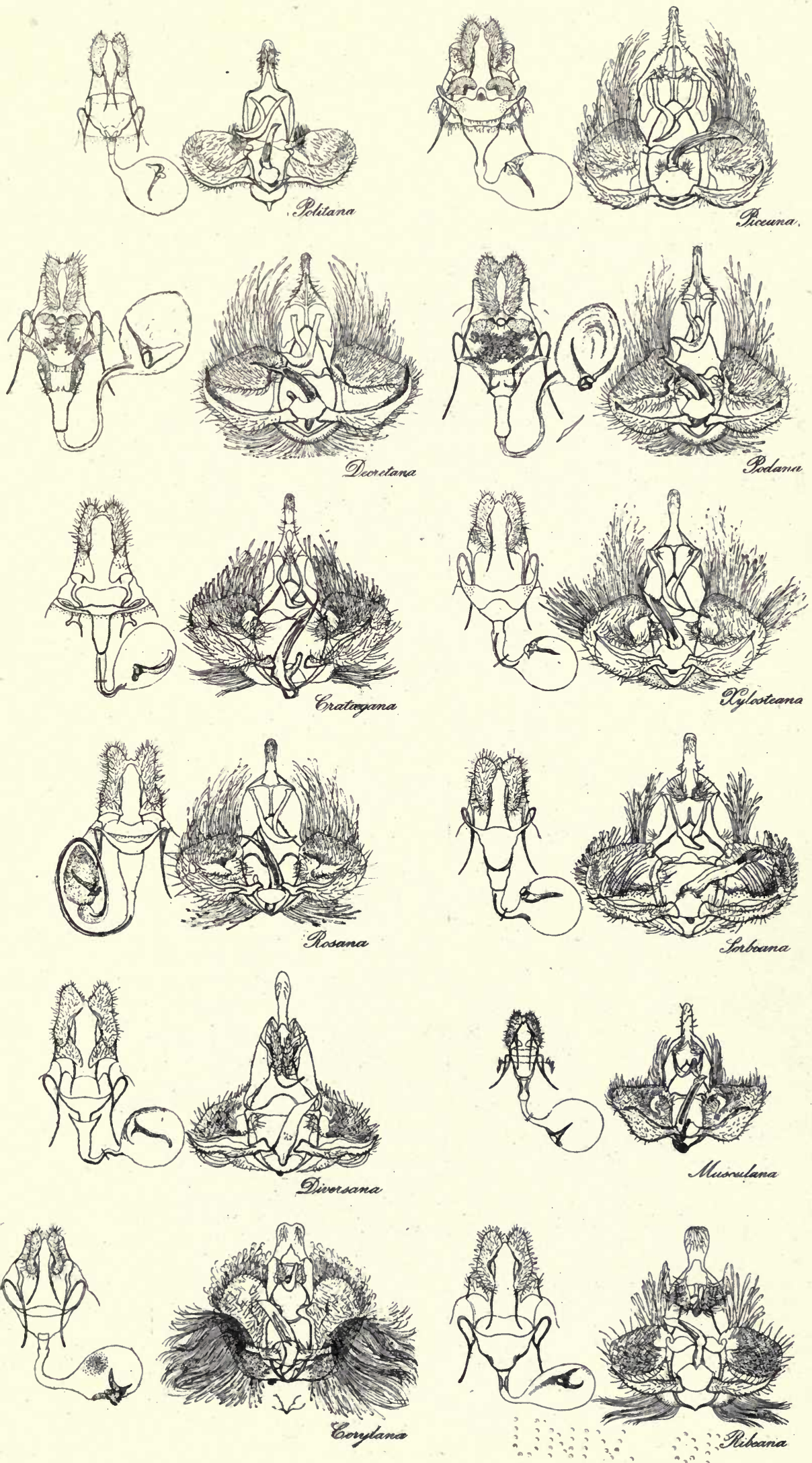


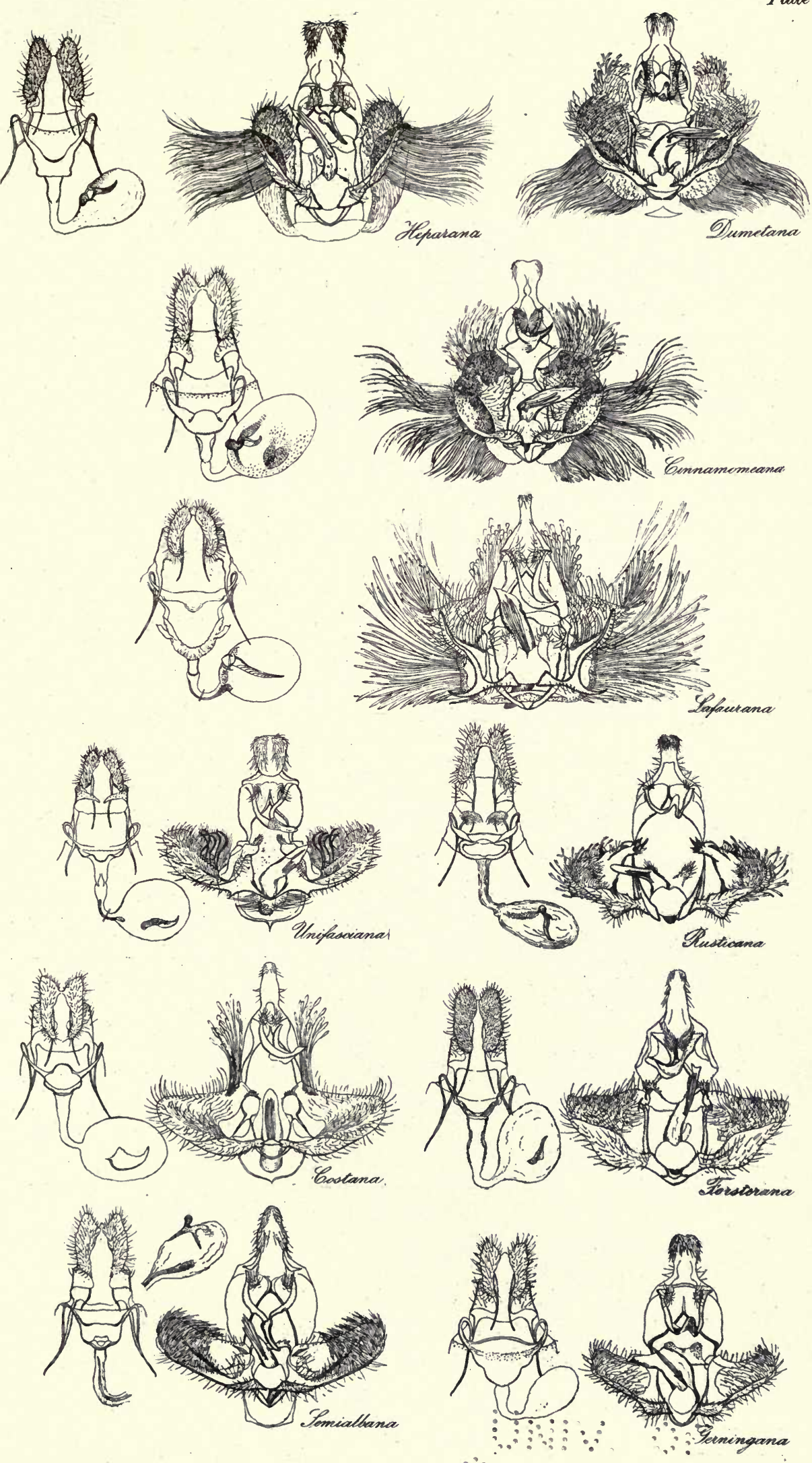


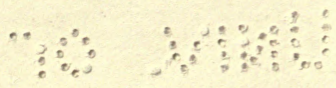

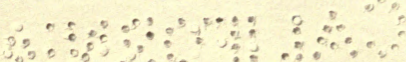




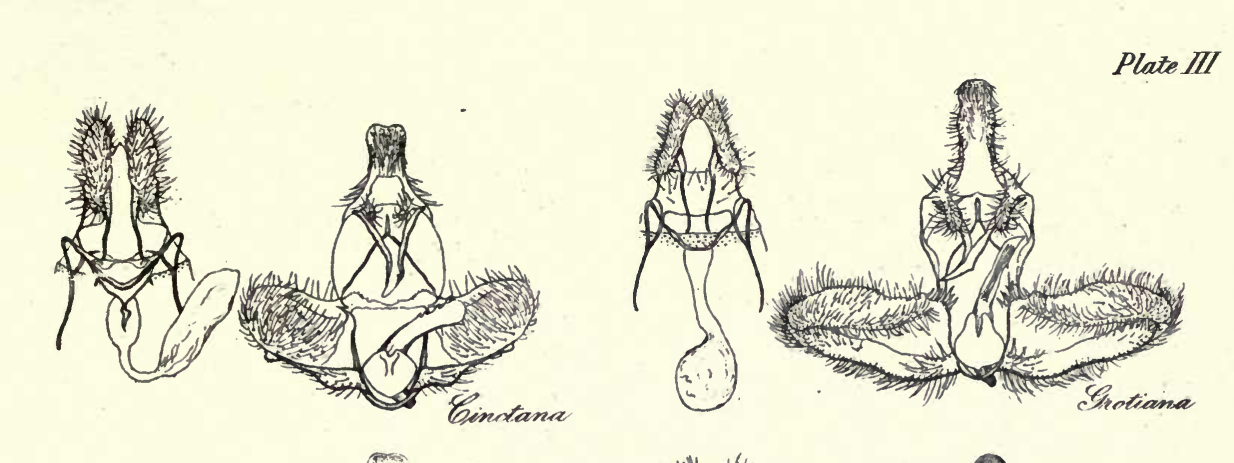

A Hes

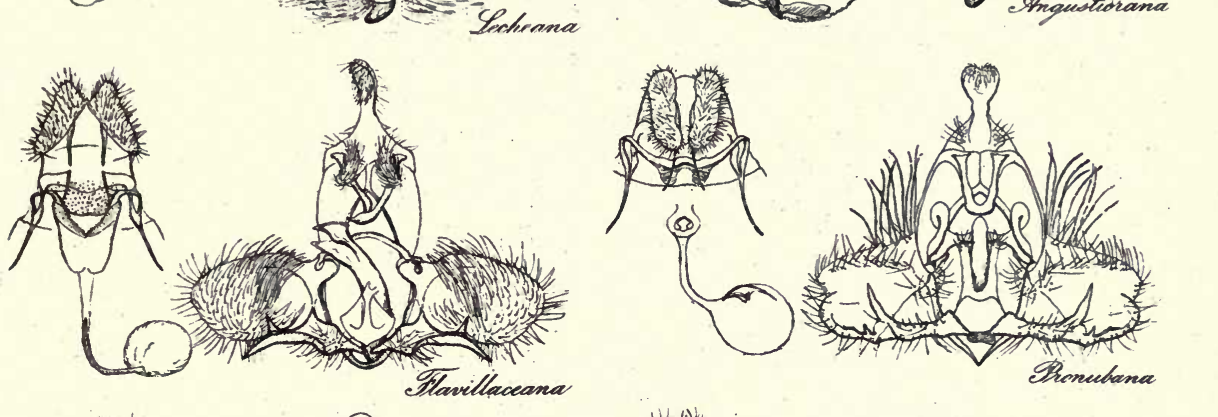

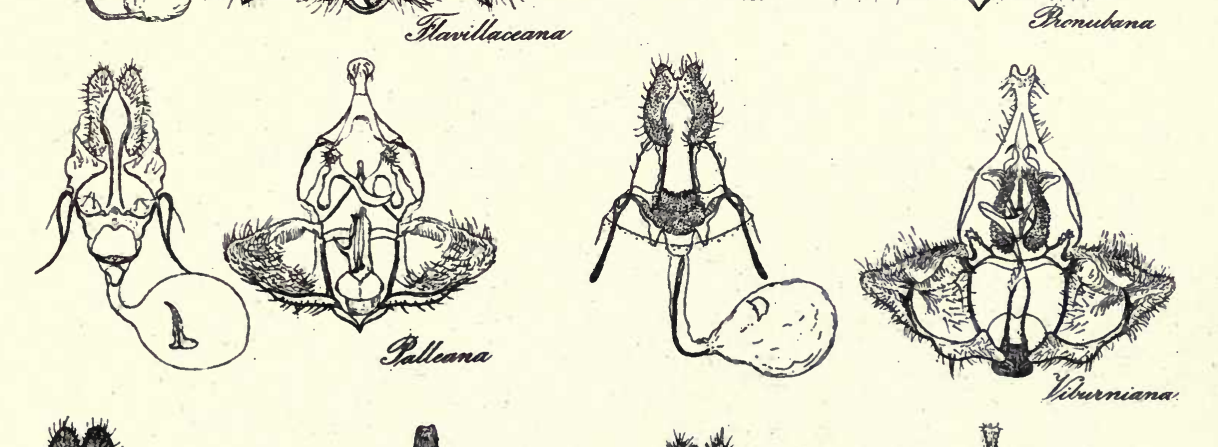

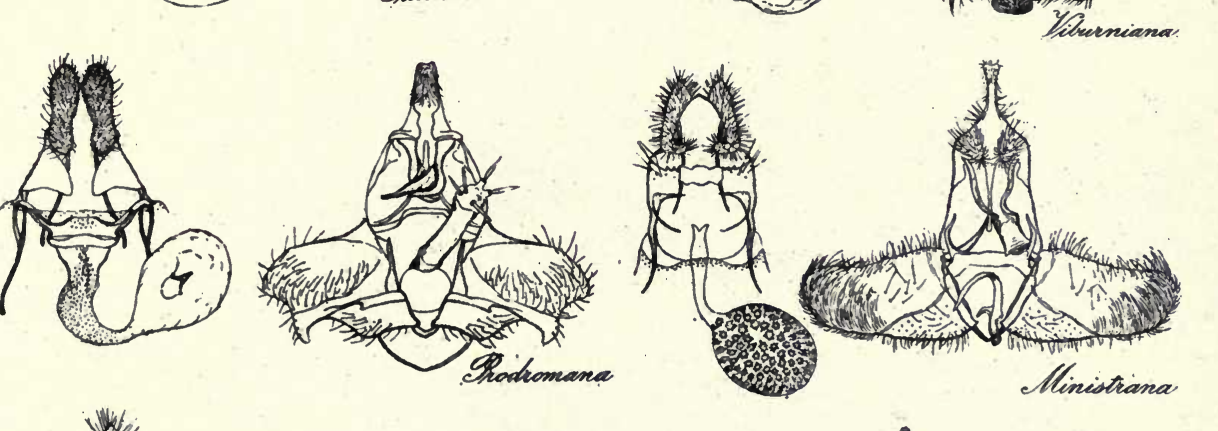

H 
$\because \because \because \quad \because \vdots \vdots \vdots \vdots \vdots$ 

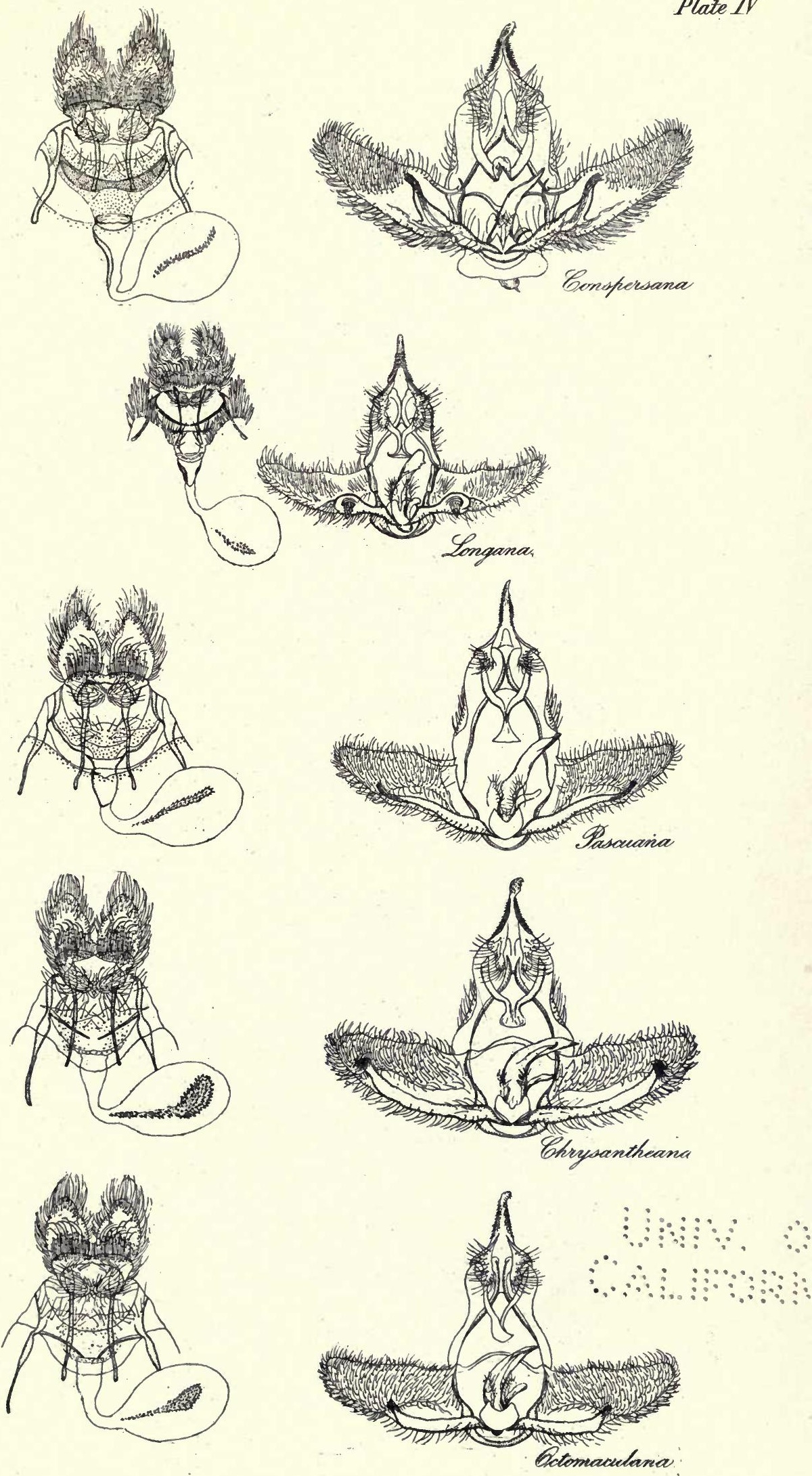

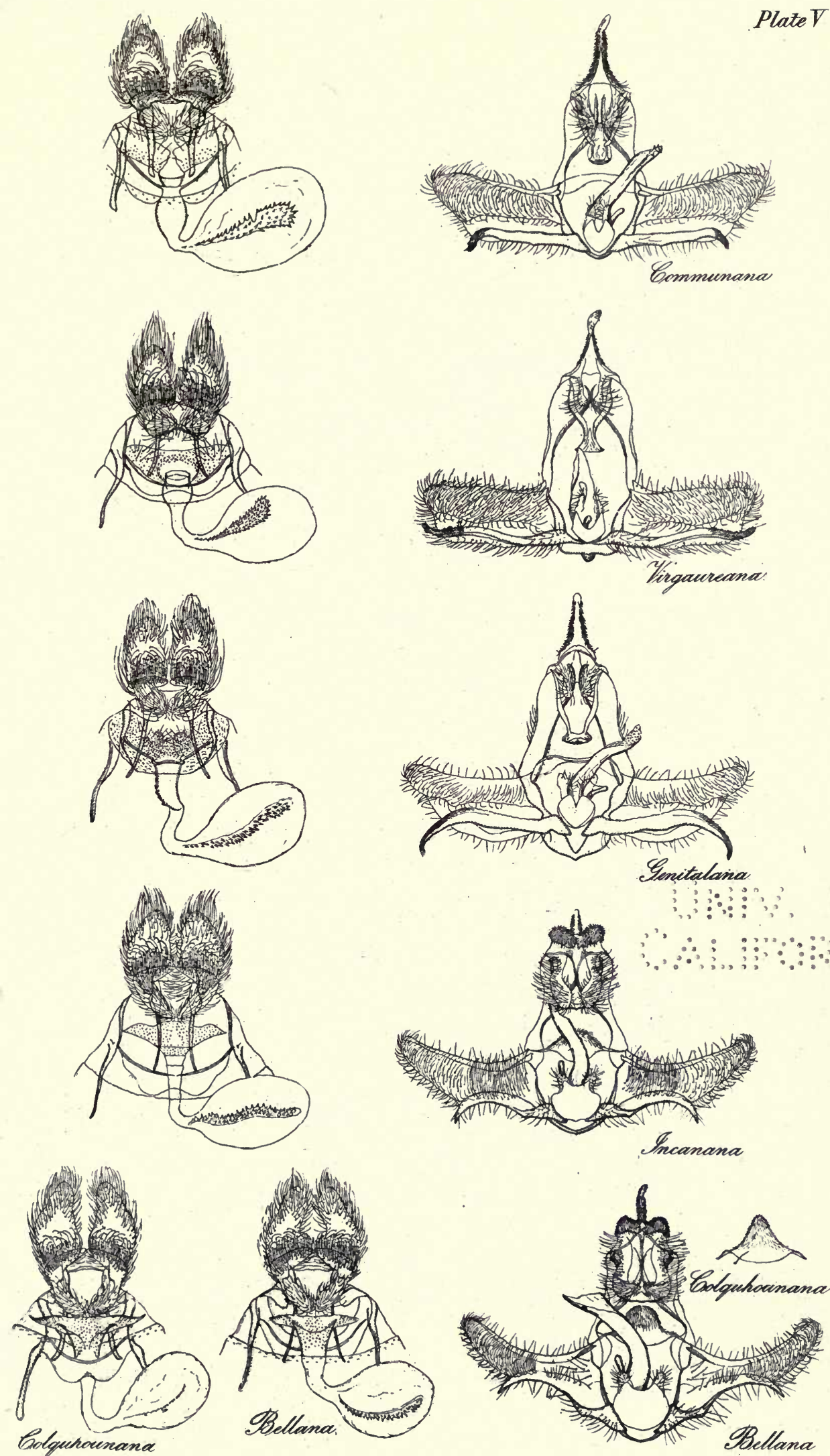

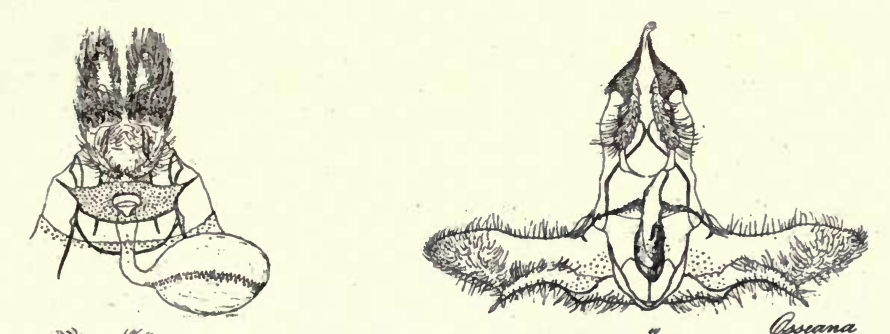

Plate VI
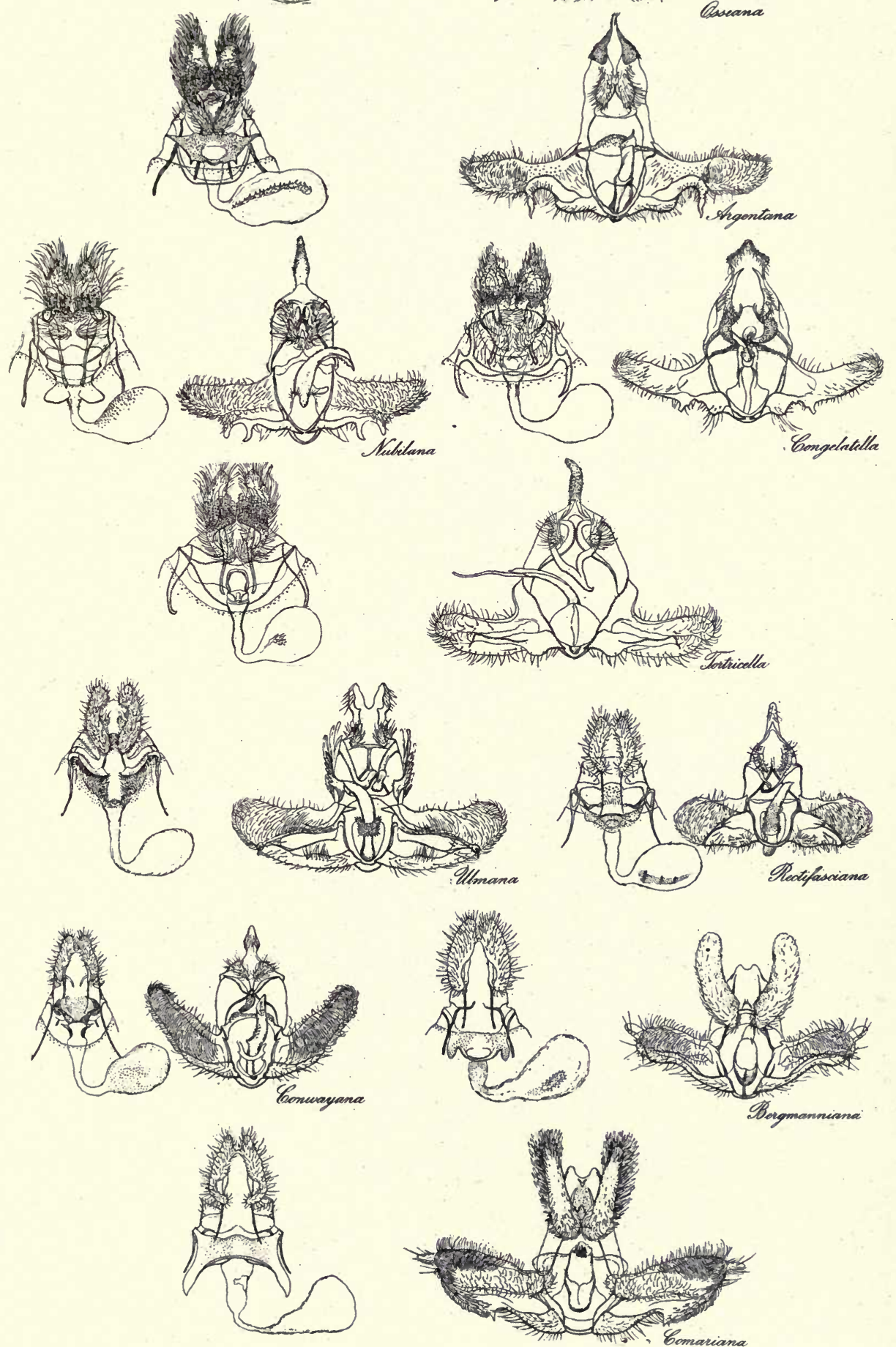


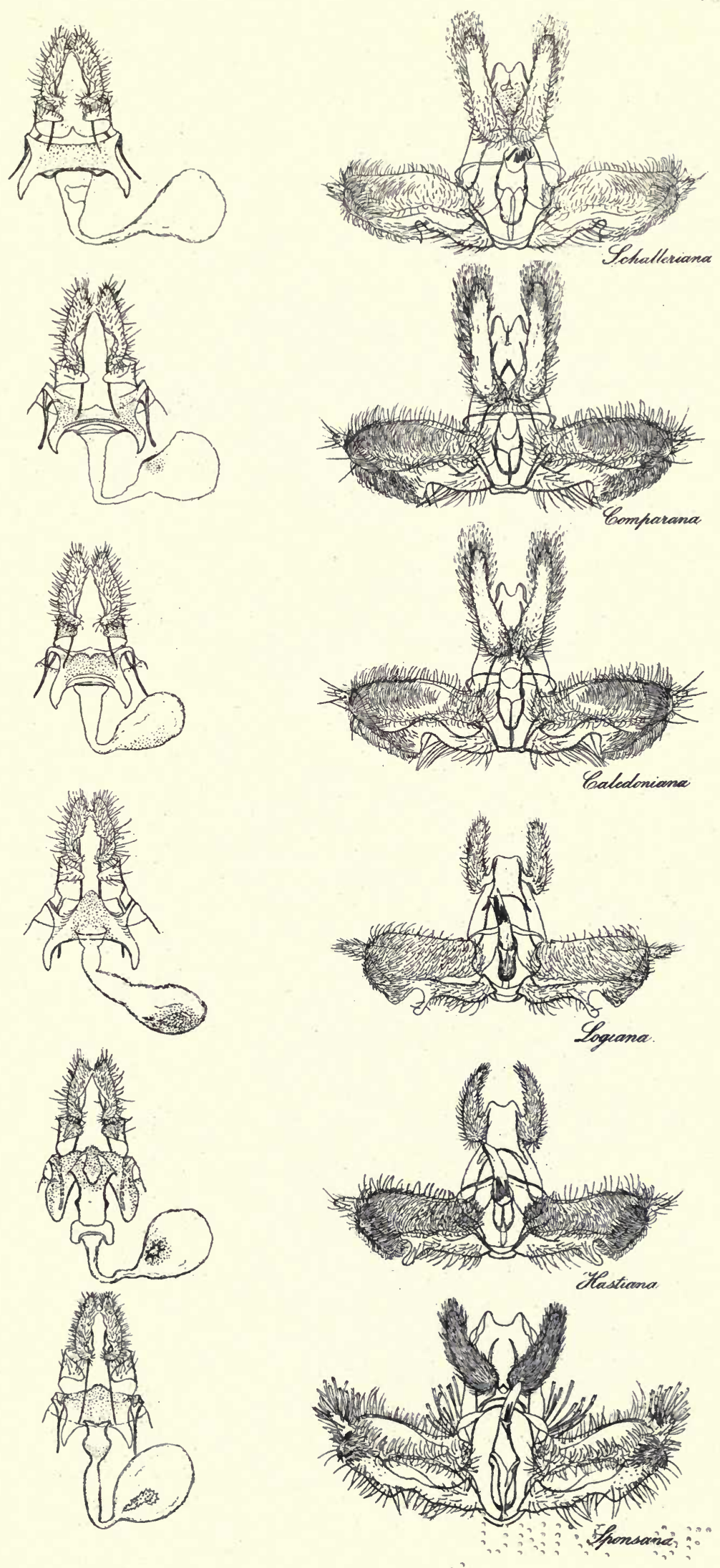
$\because \because \vdots 0 \quad \because \vdots \vdots \vdots \vdots \vdots$

$\therefore: \therefore: \because \because n: \vdots \therefore:$ 
Plate VIII
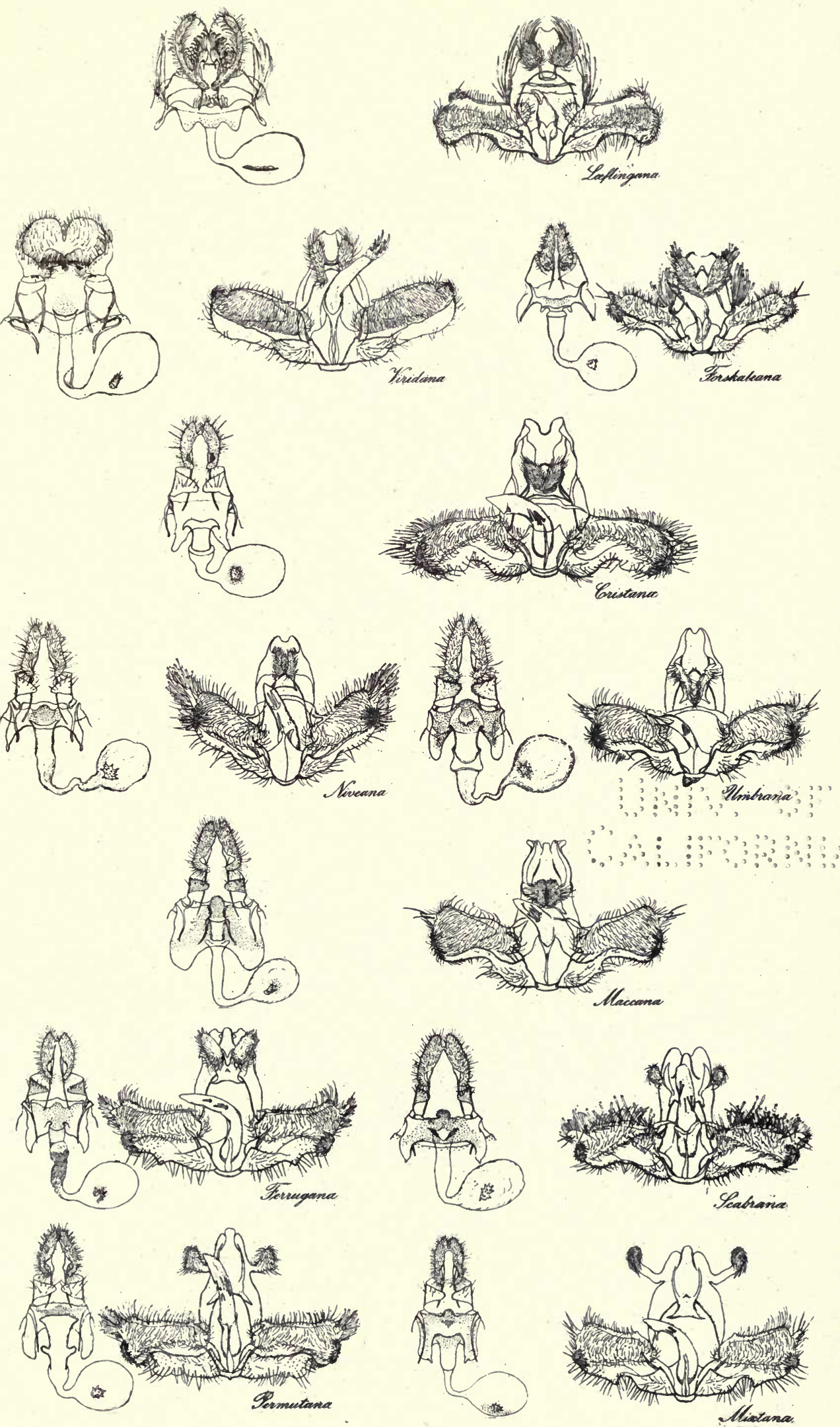


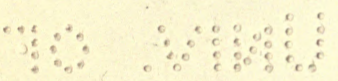

$\therefore 3$ 

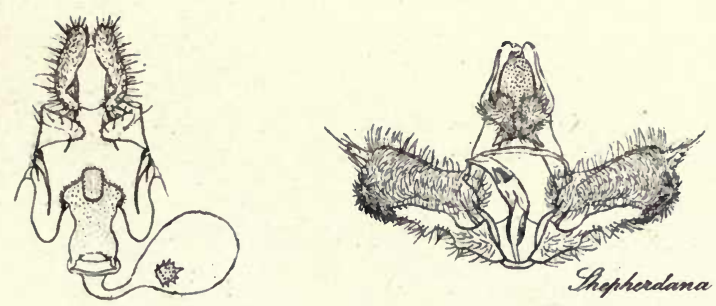

\section{Plate IX}
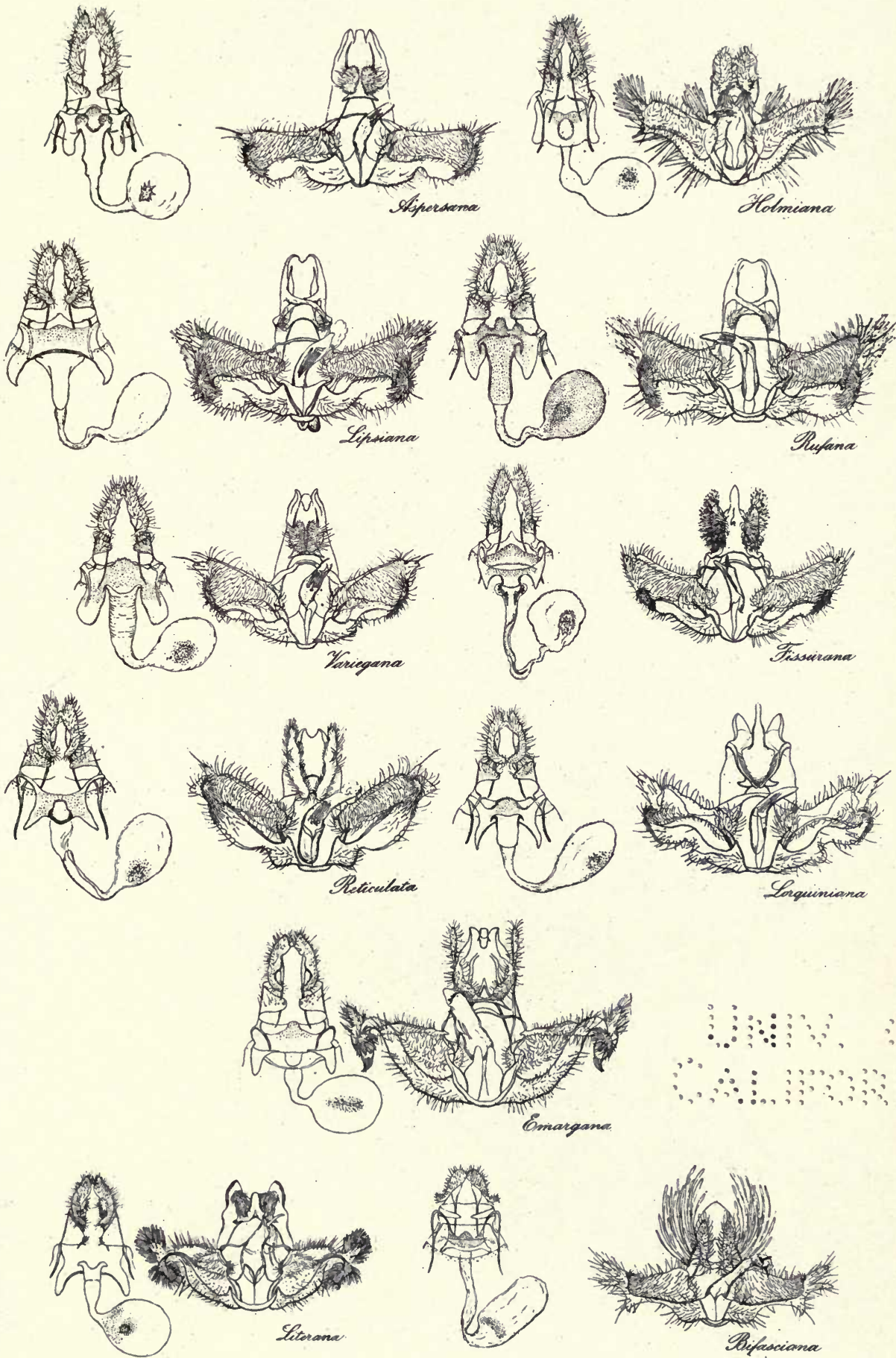


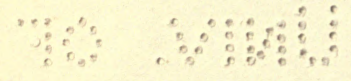

a 


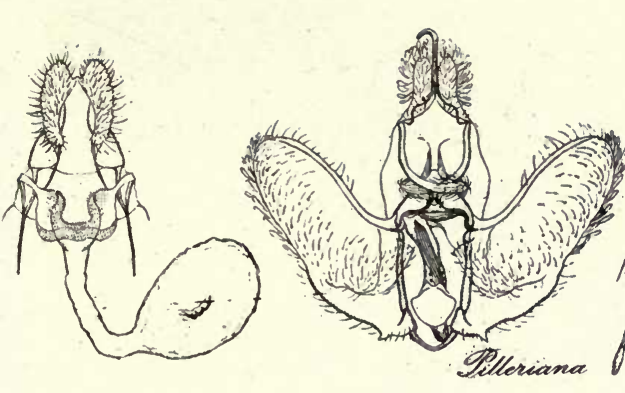

Plate X.
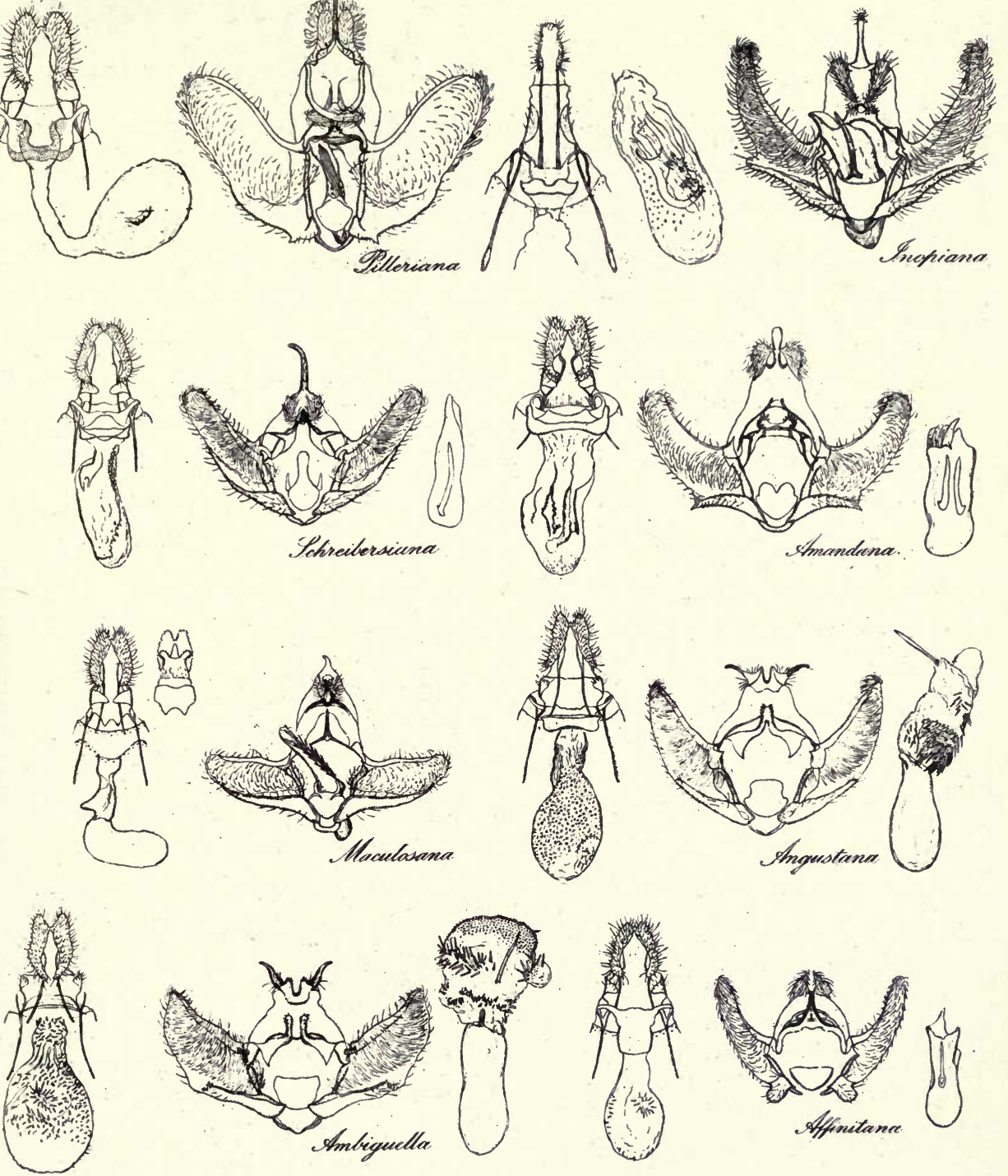

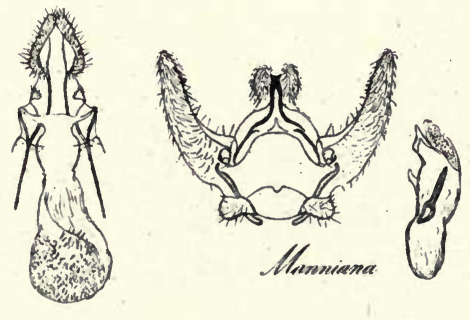
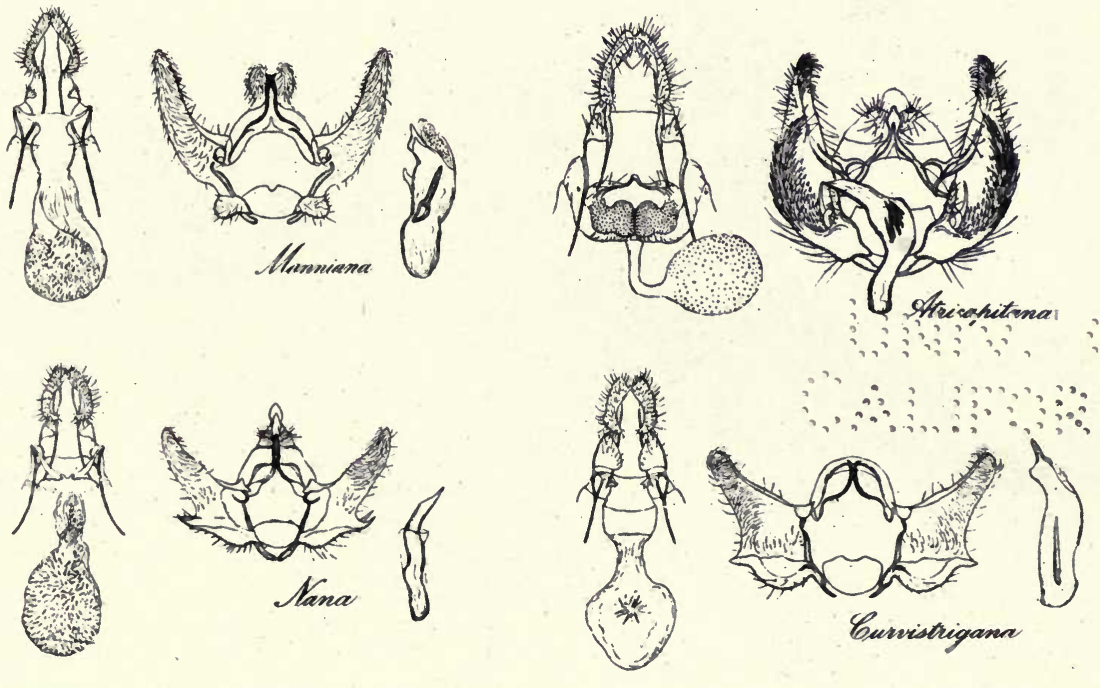


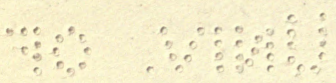

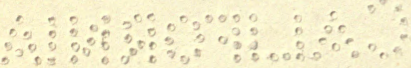



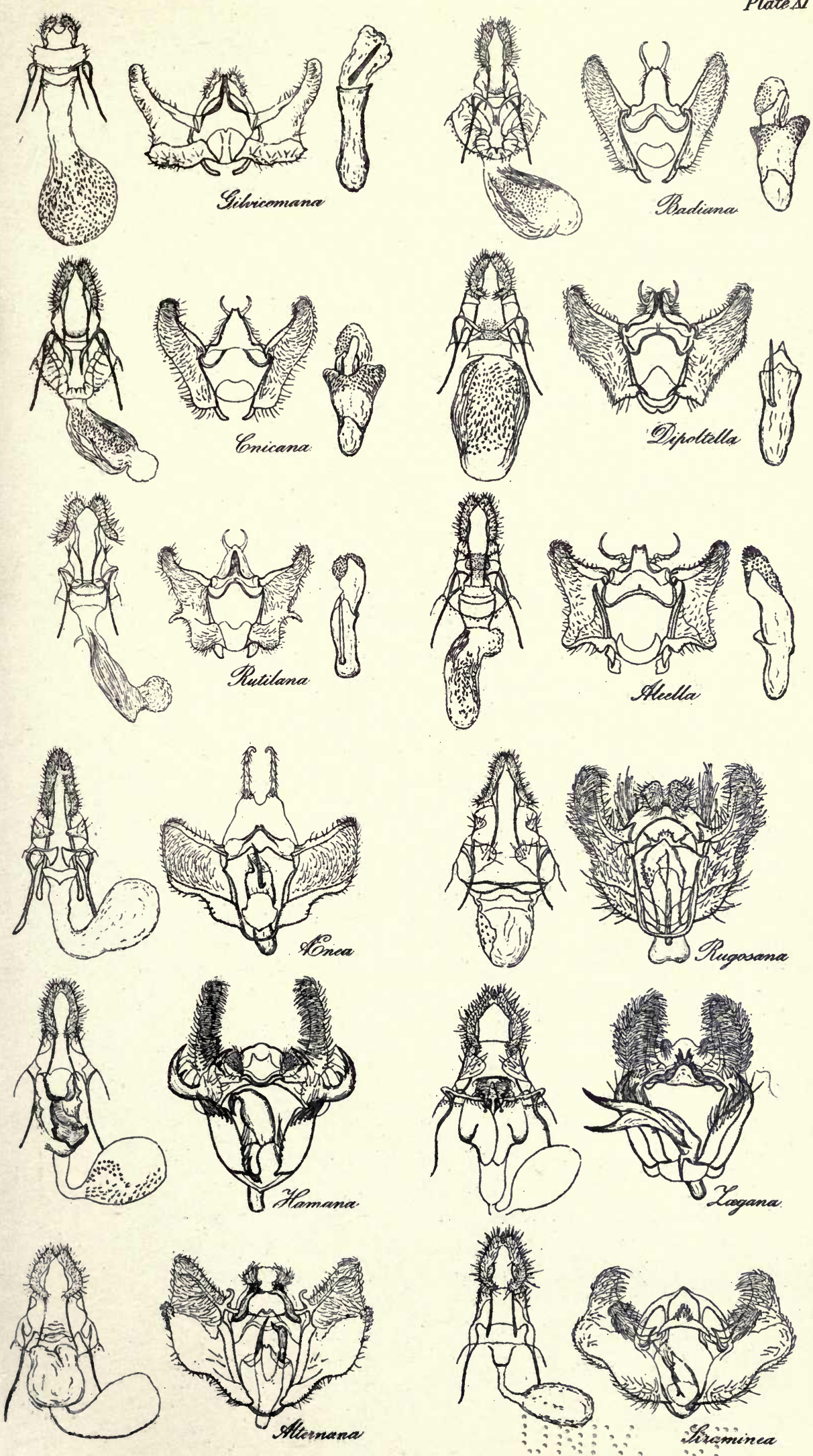


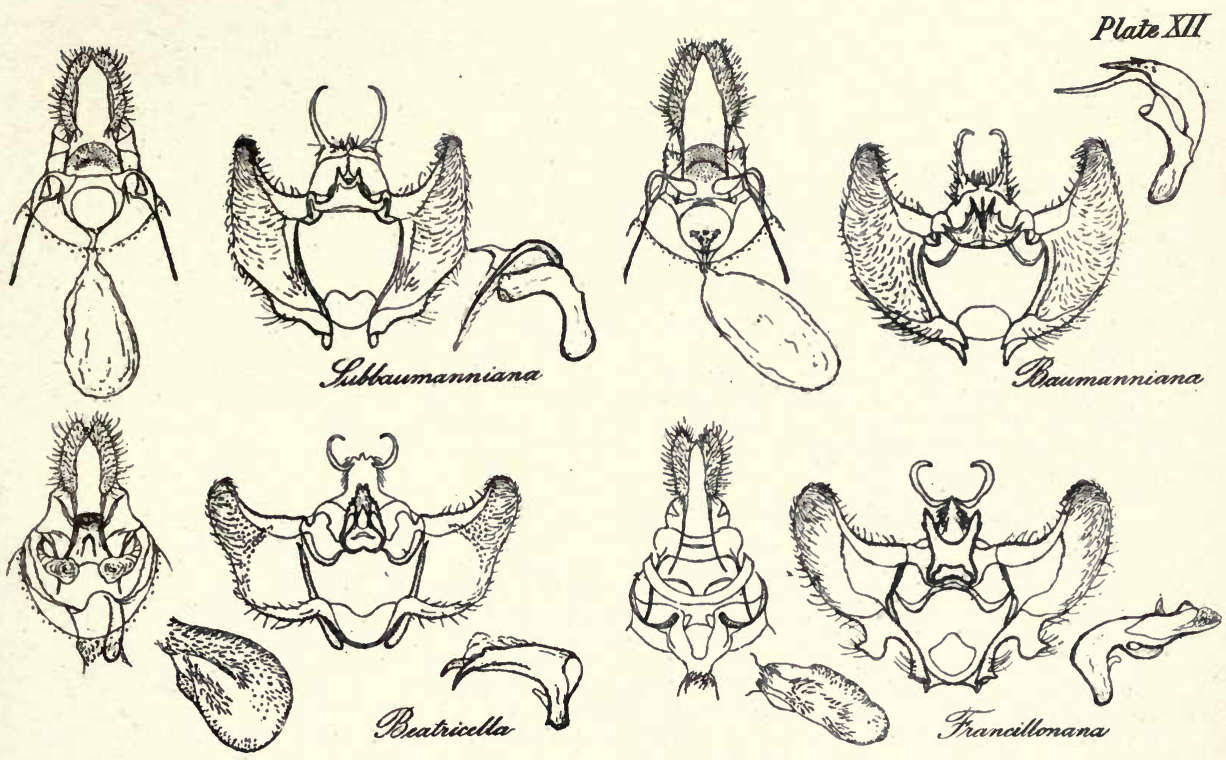

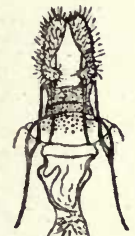

(2)

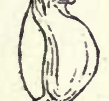

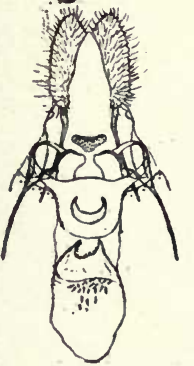
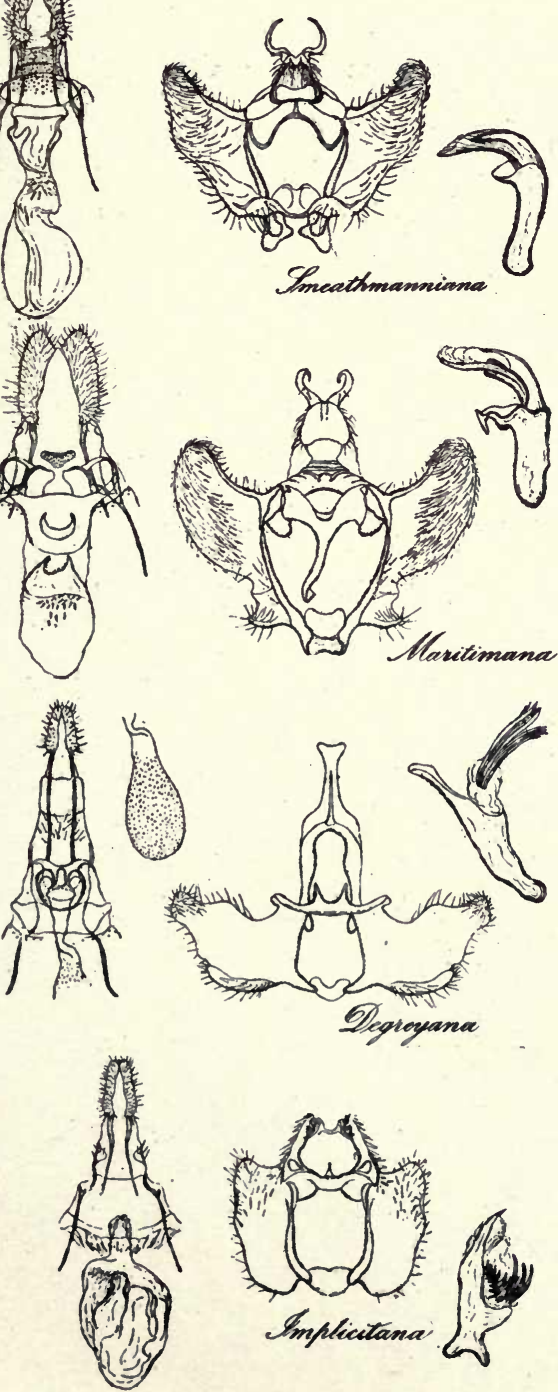
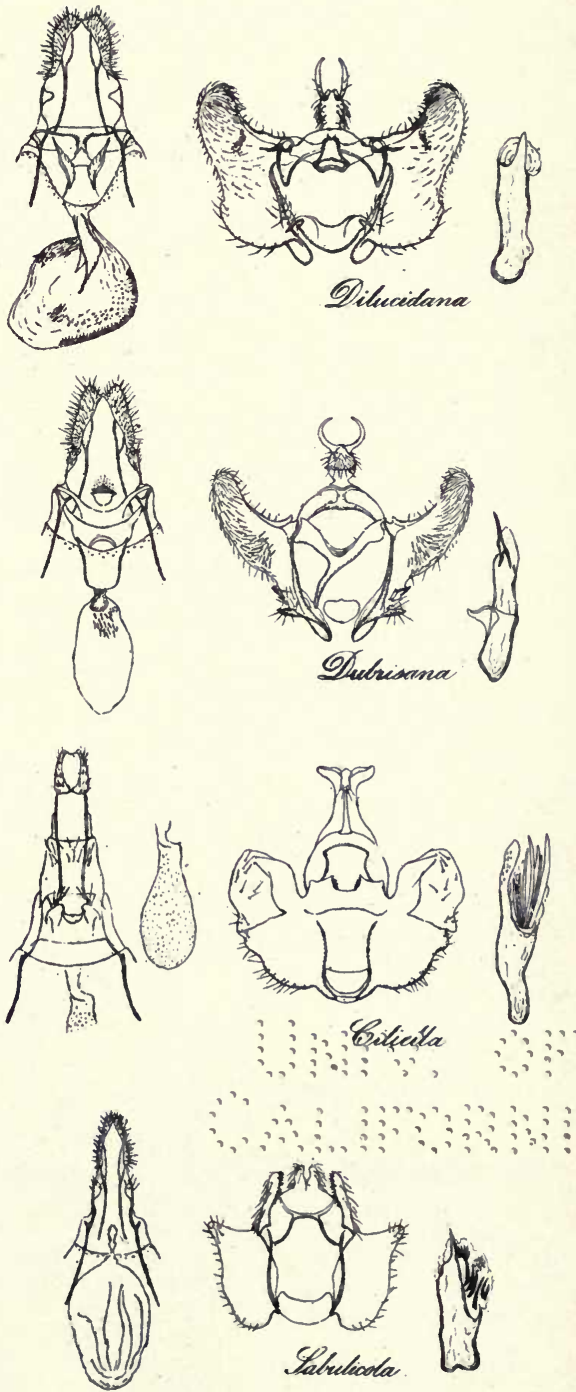


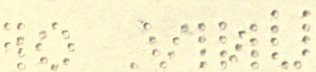

$\therefore \quad 5000=000 \%$ 


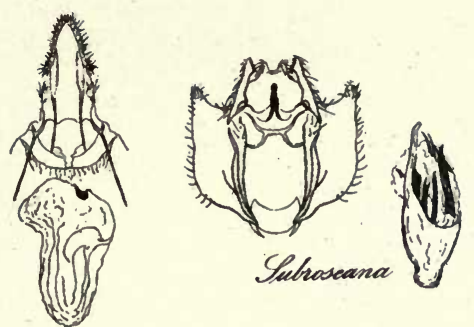

PlateXIII
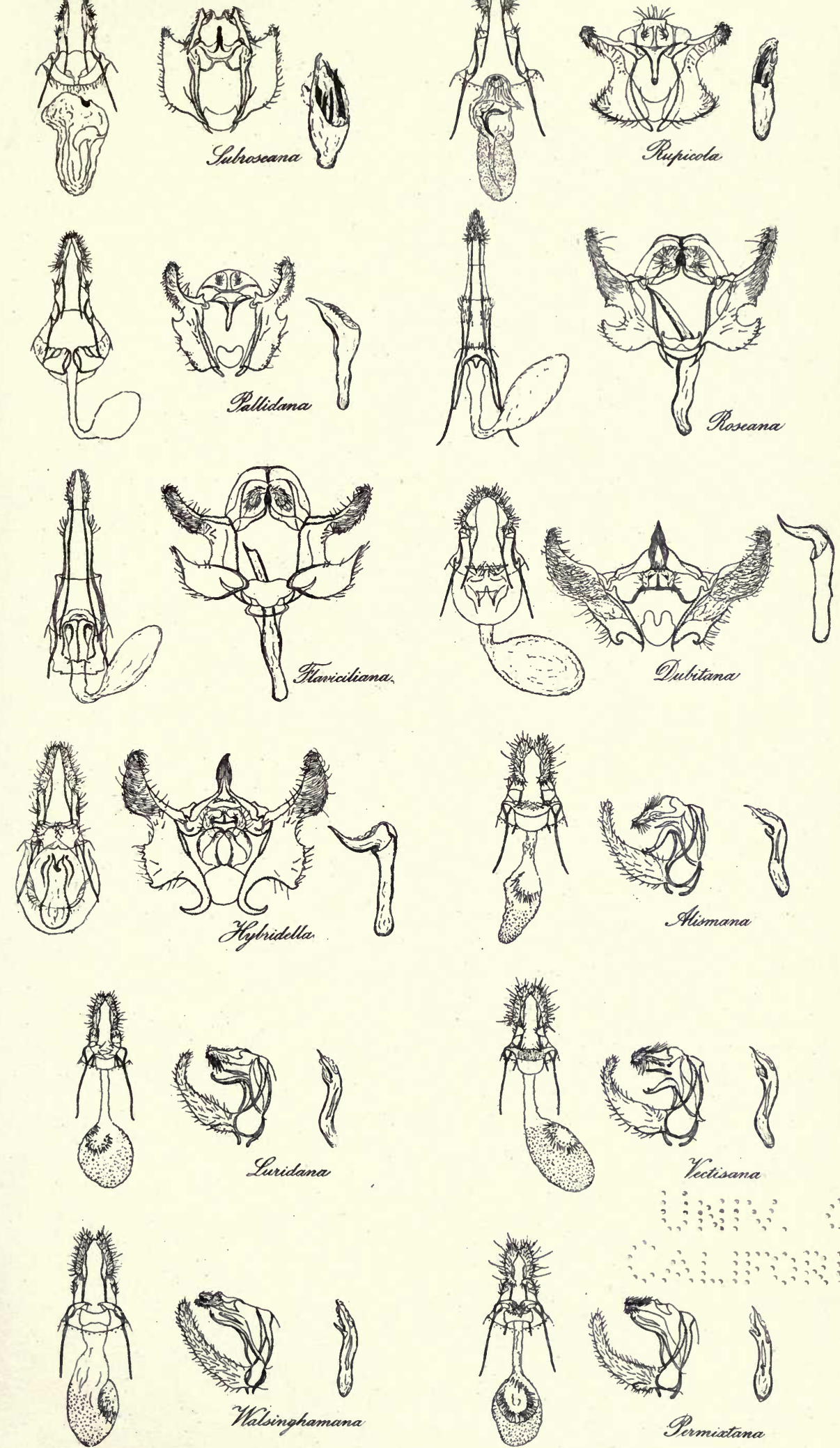


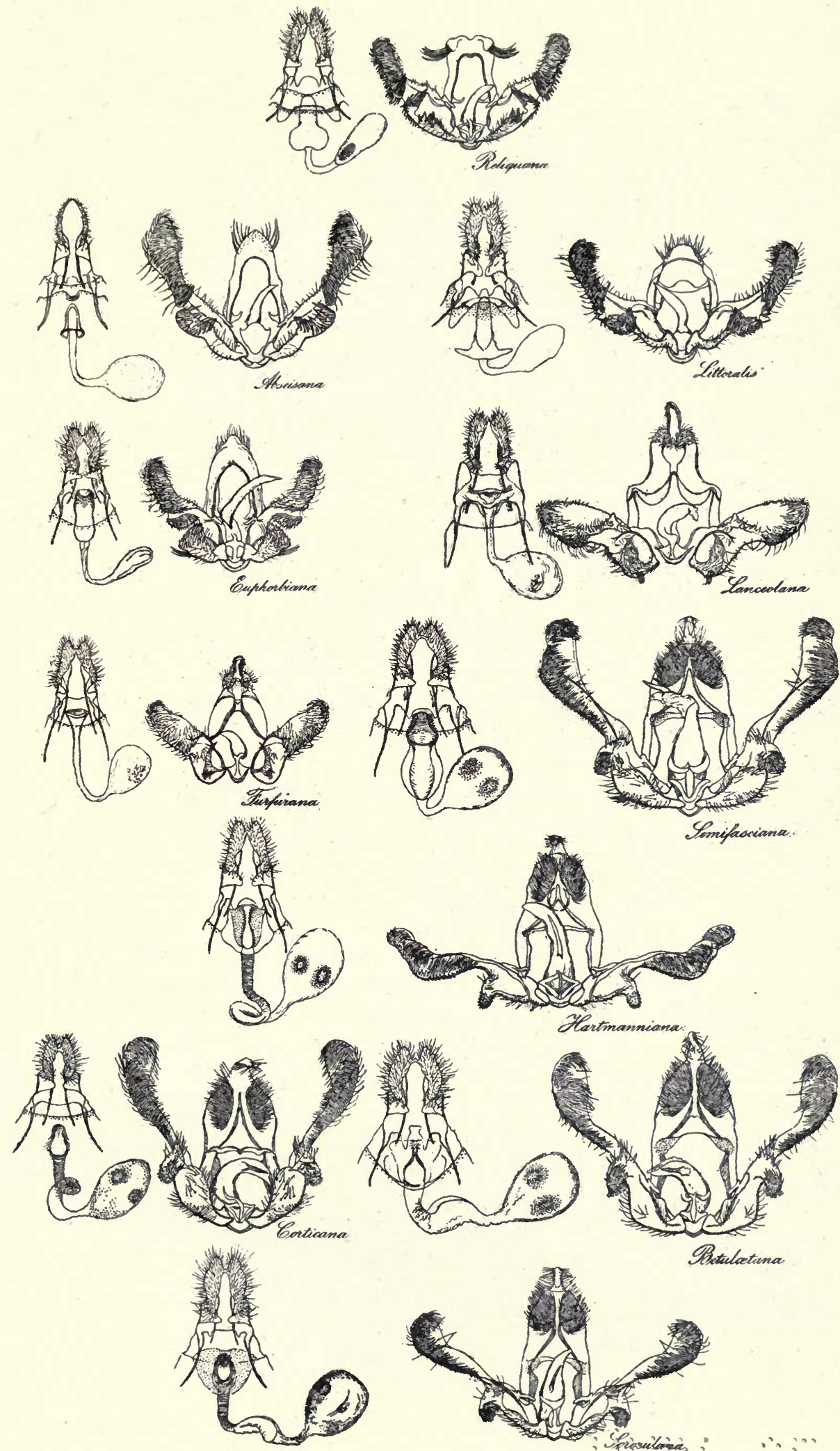



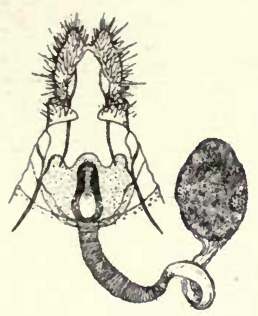

Plate XV
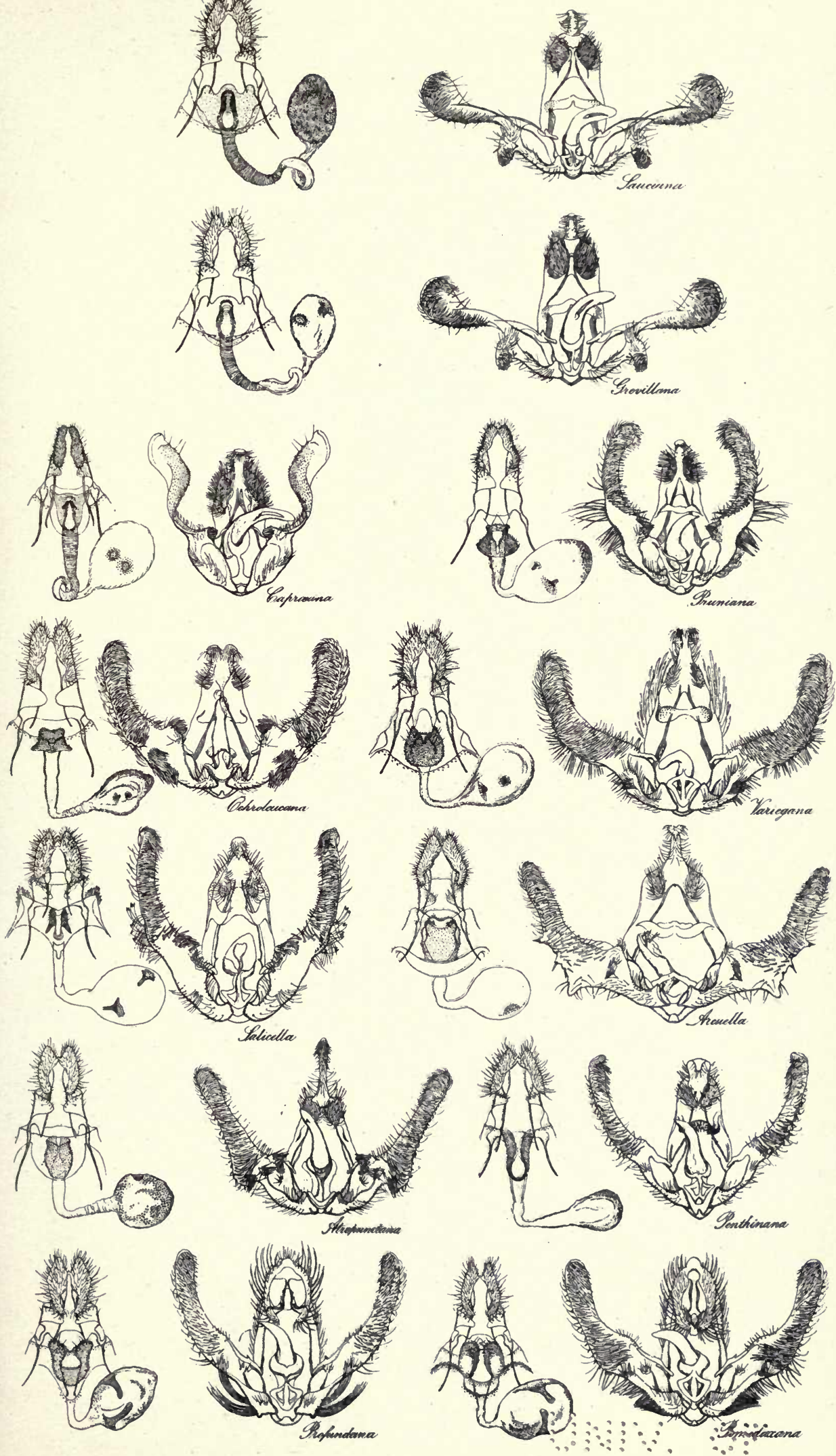
$\because \vdots: \quad \because \because \vdots \because \vdots \vdots$

$\therefore:: \because \because \because \because \because n: \vdots \therefore \square^{\circ}$ 

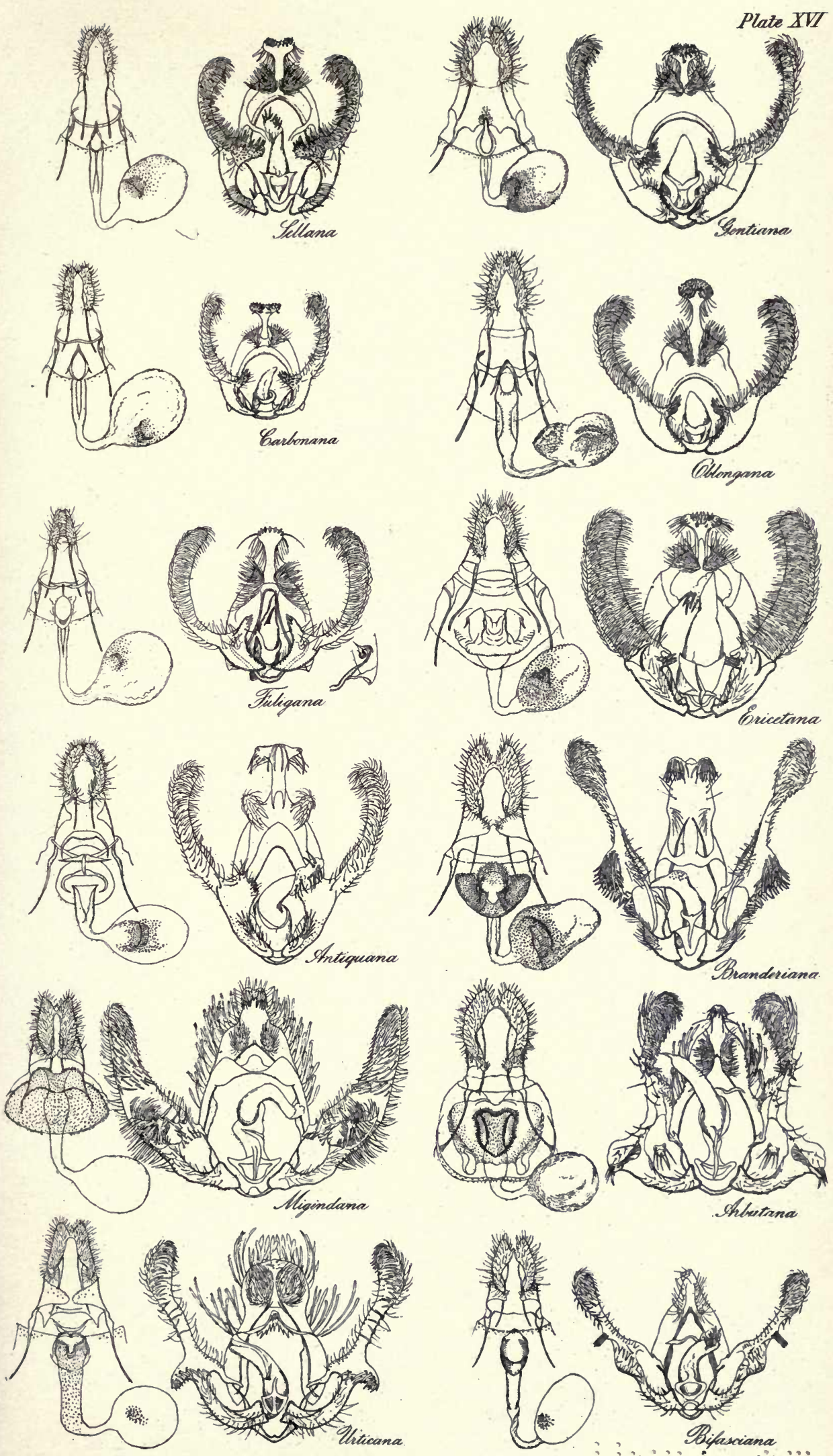


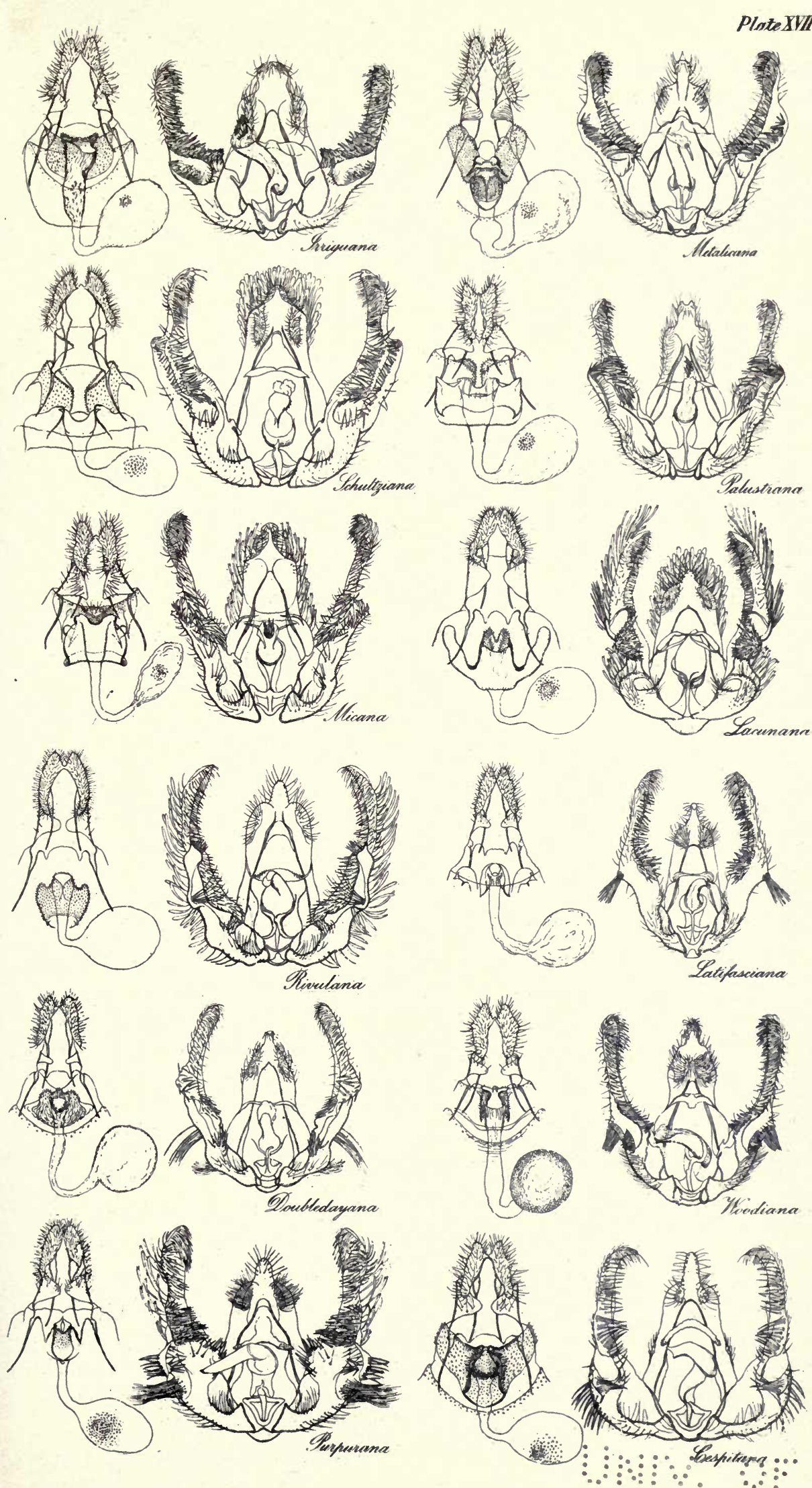


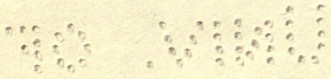



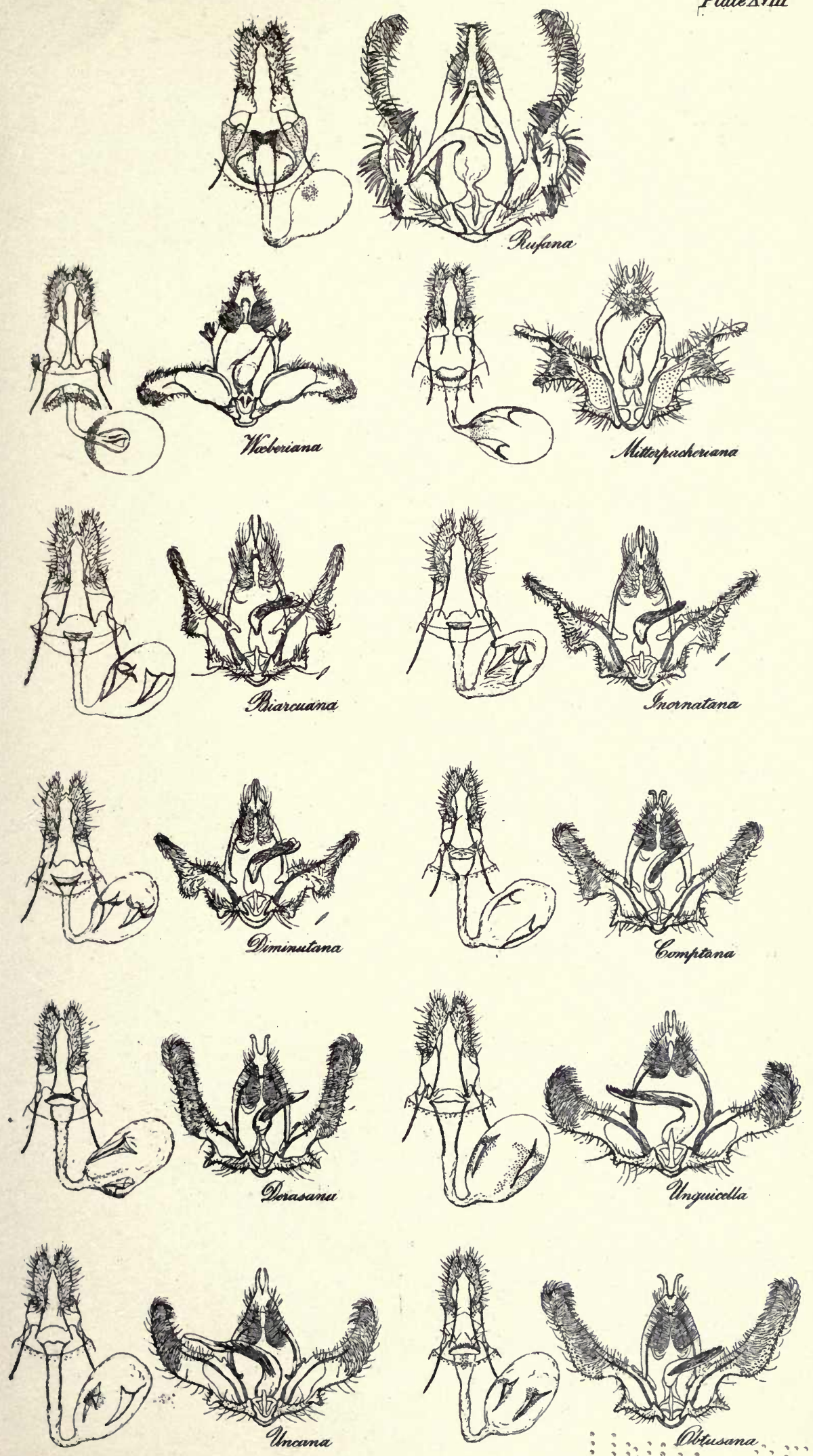


Plate XX
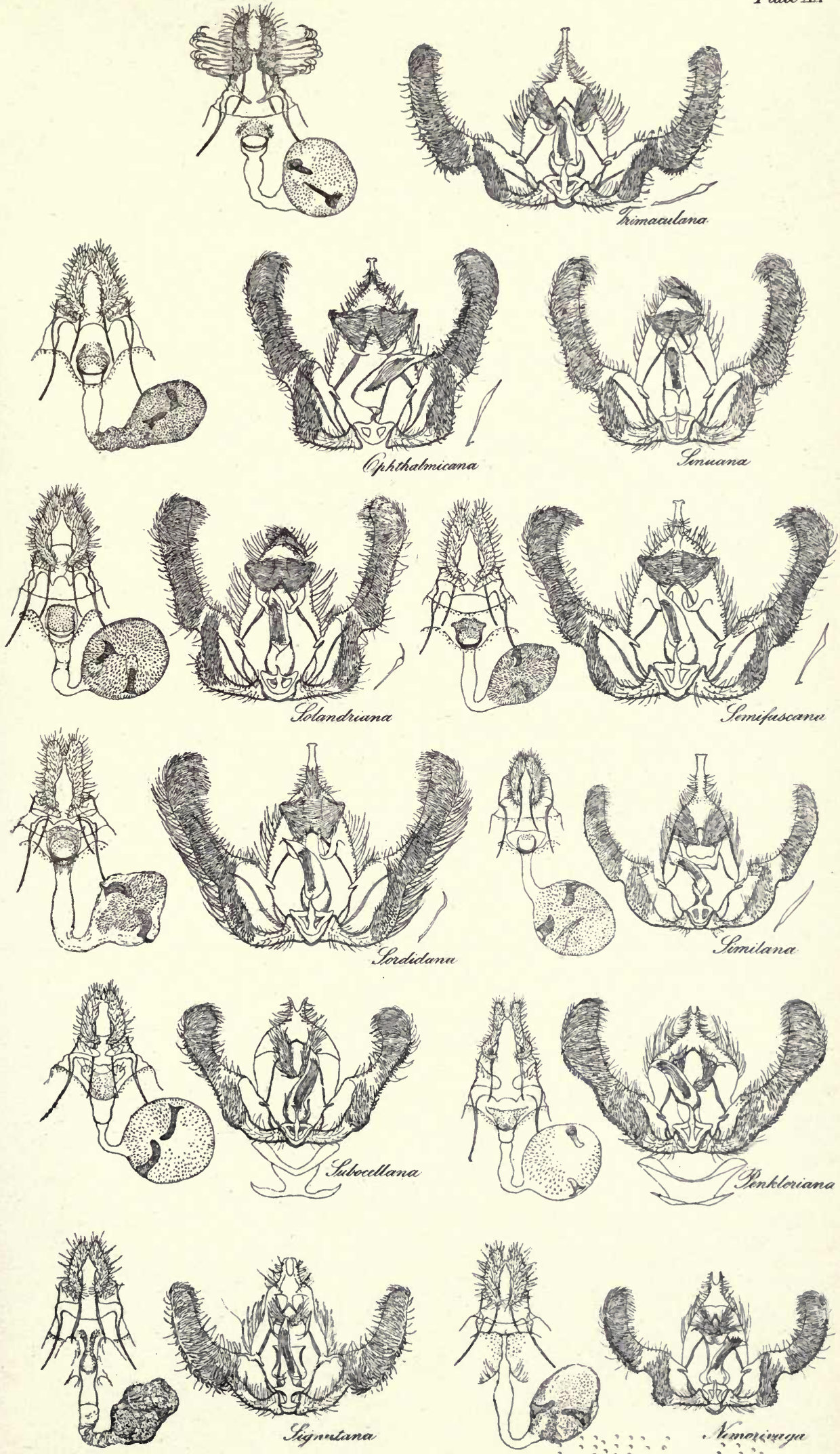
$\because 0^{\circ} 0 \quad \quad \because \vdots \vdots 00: 00$ 

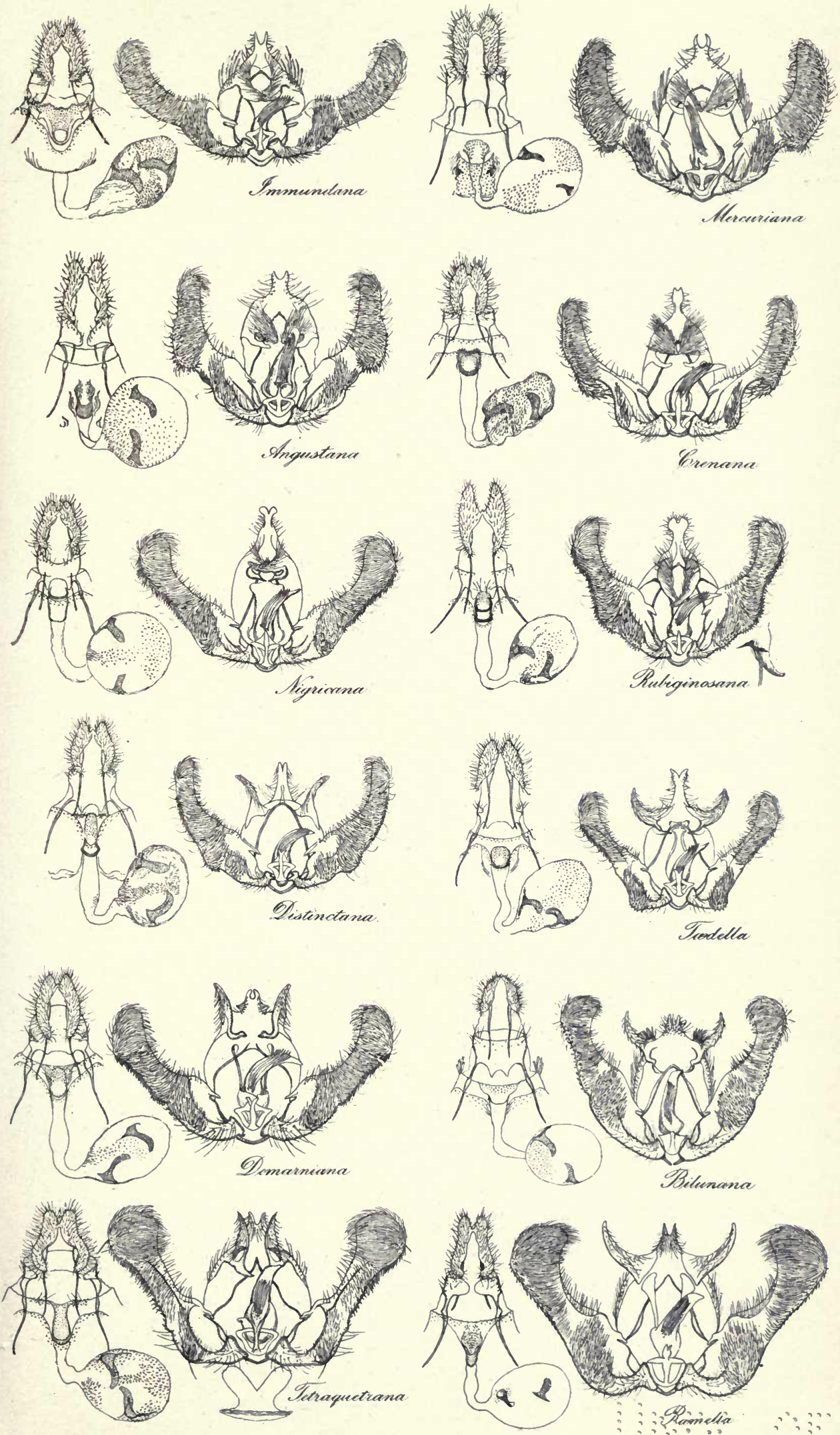

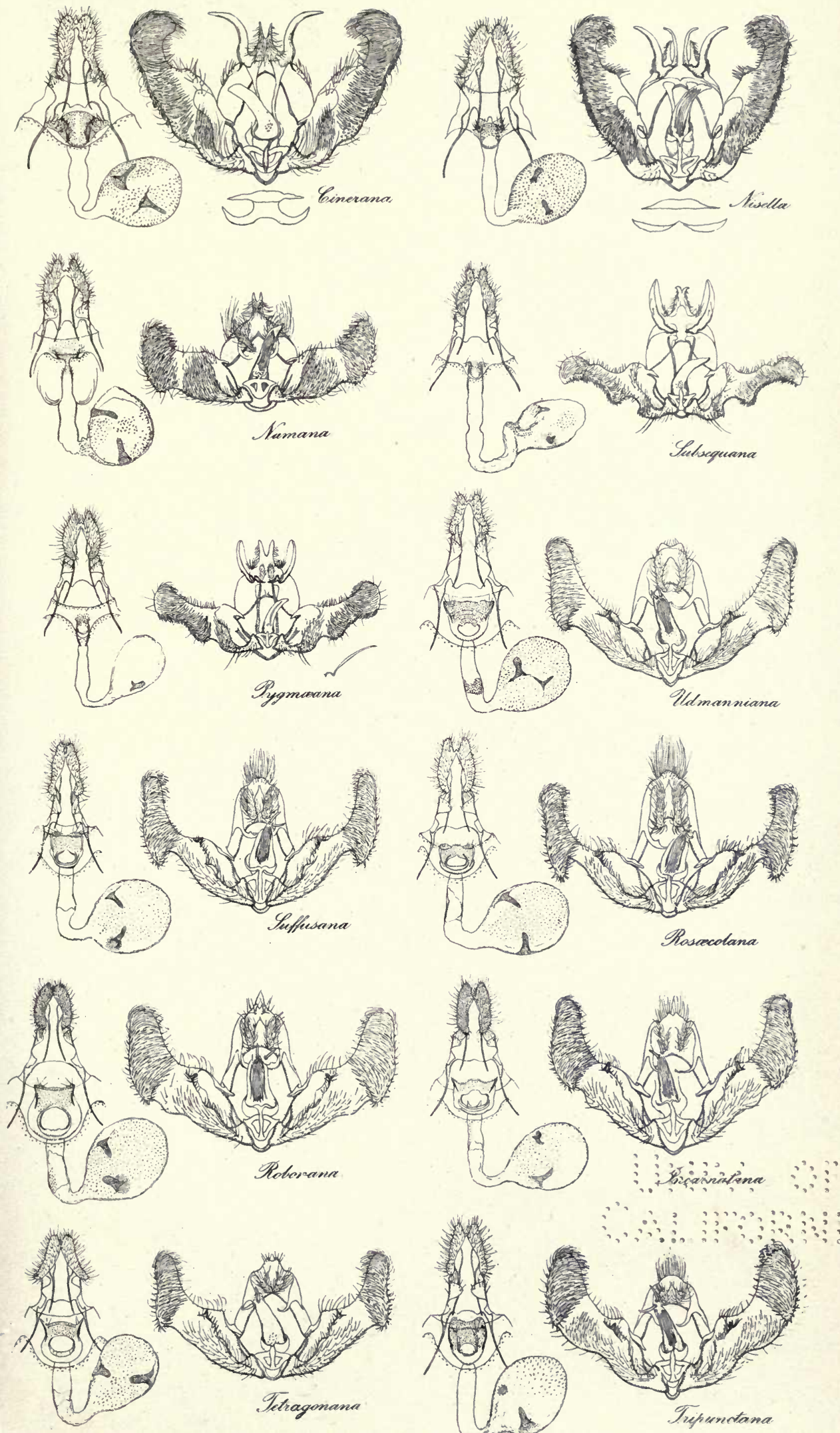
an 

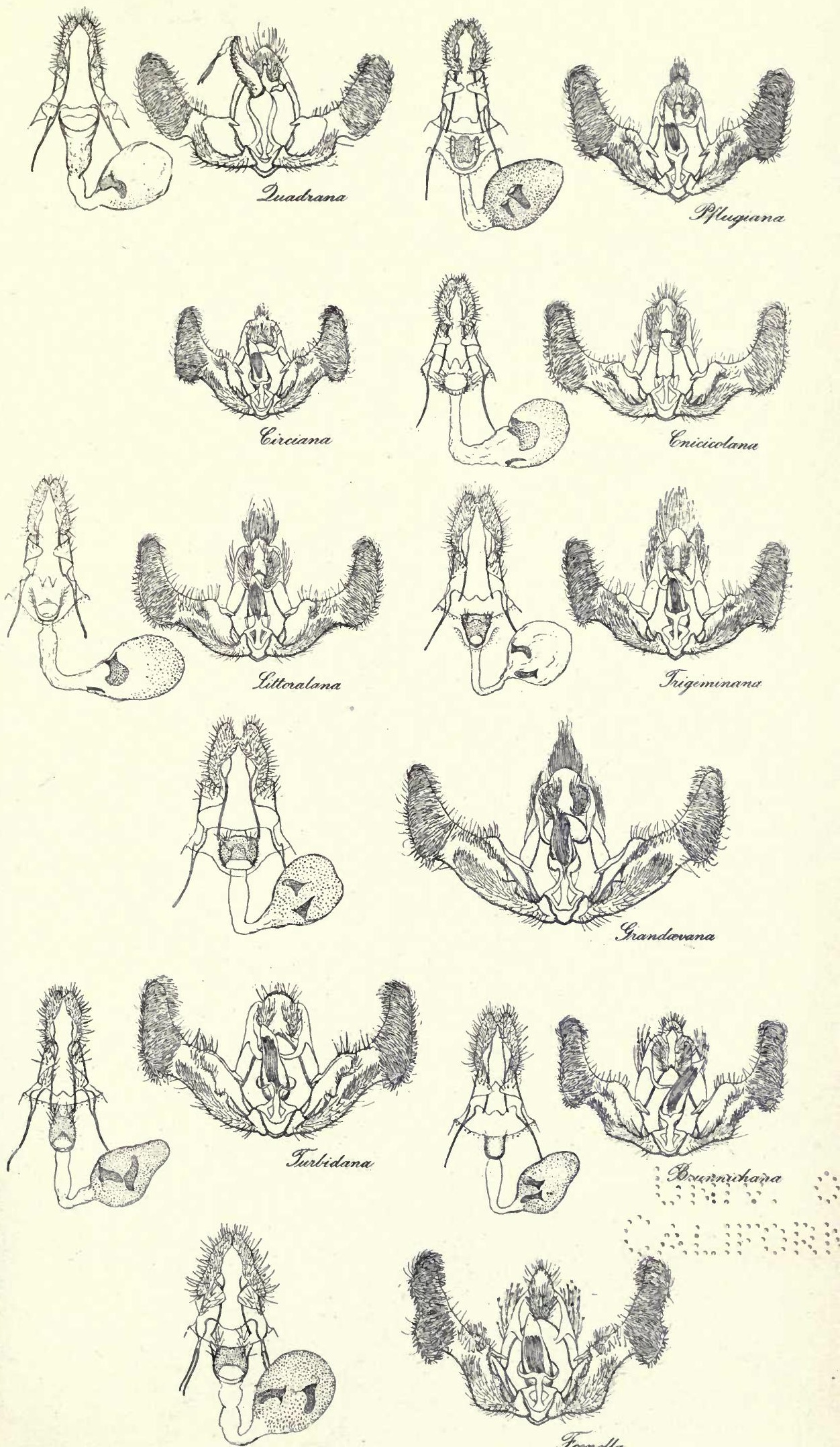

Sarferrara
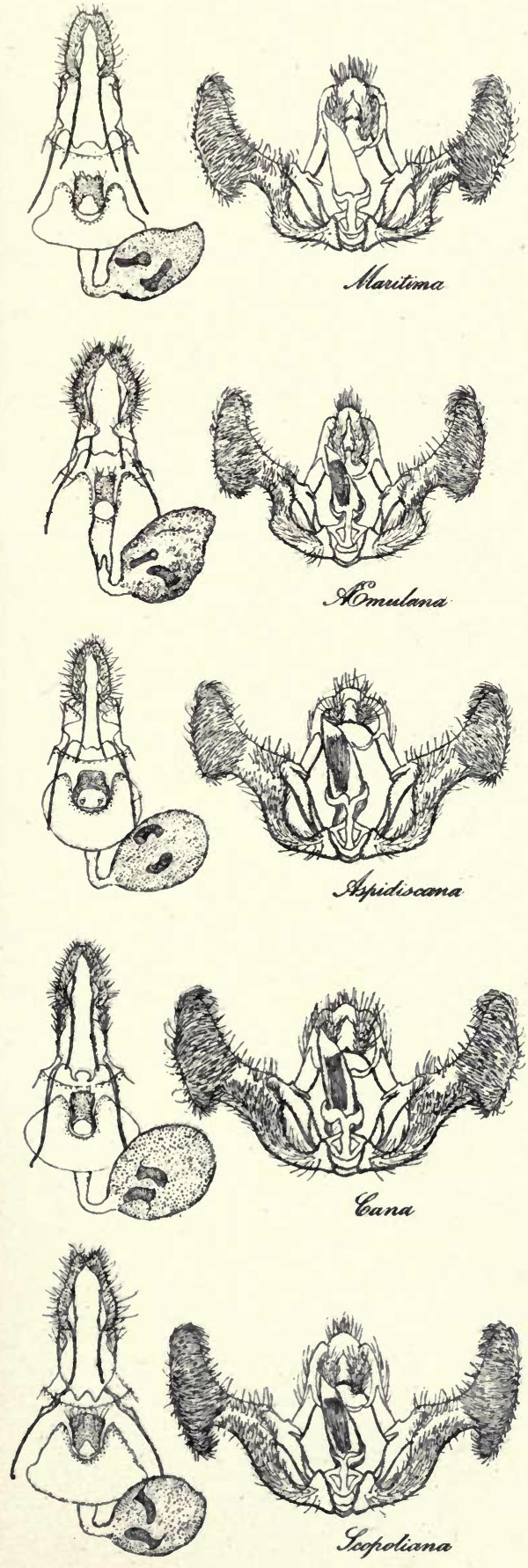
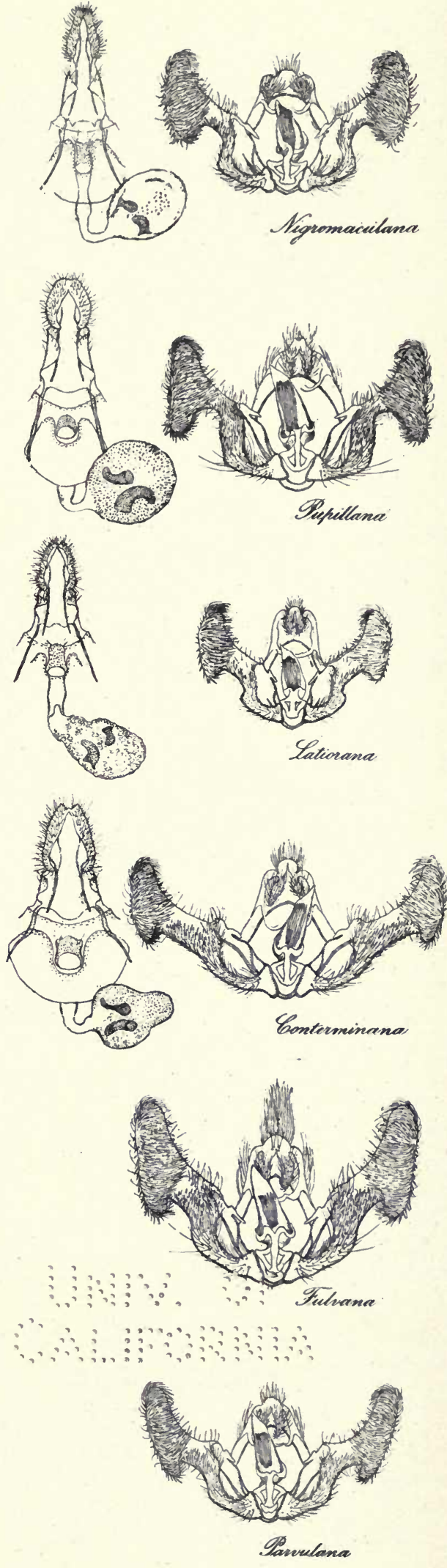
$\because \cdots \quad \therefore \quad 30$ s.ond 


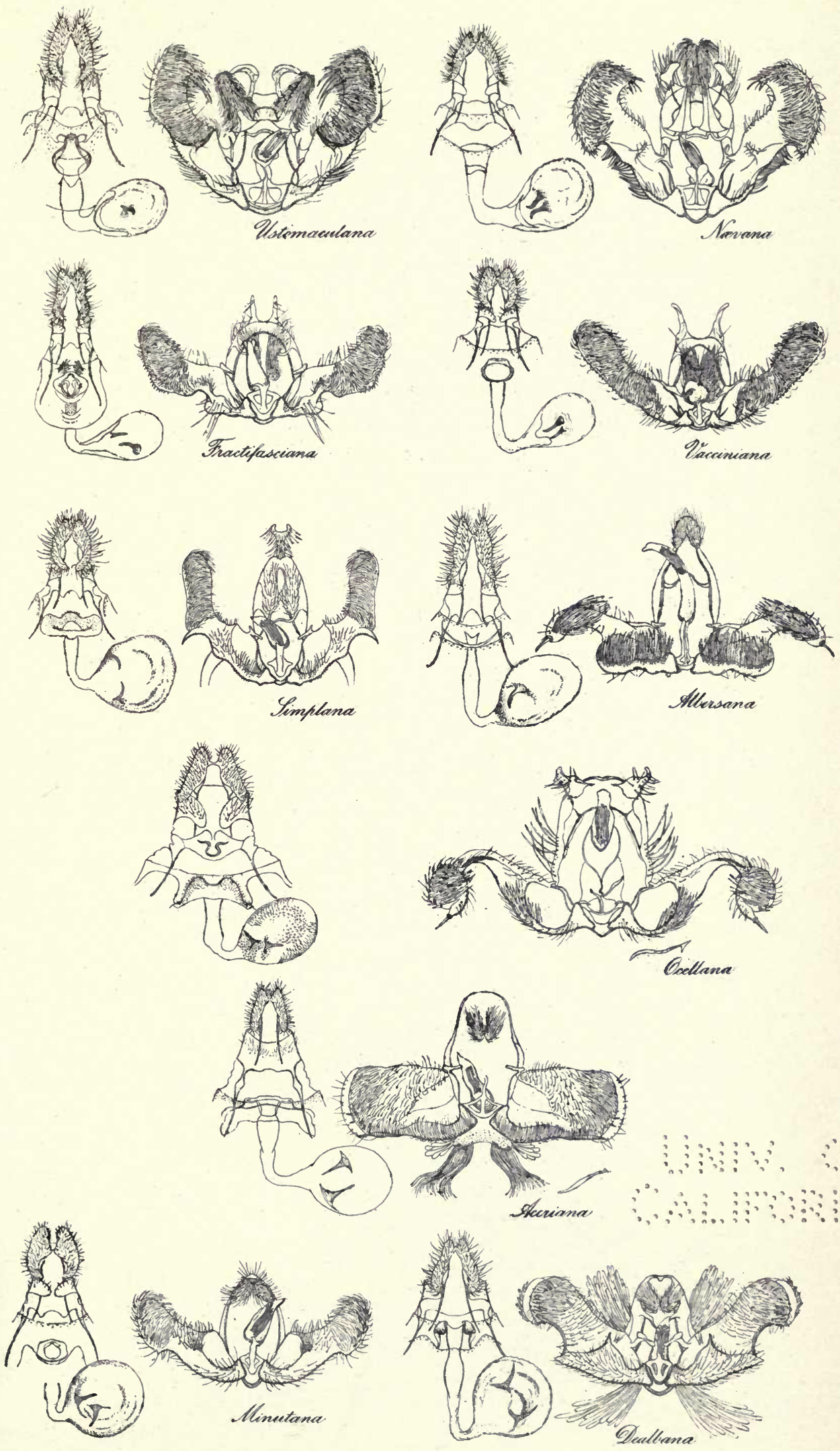



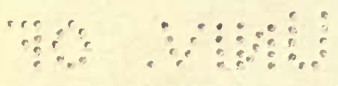

$\therefore$ 

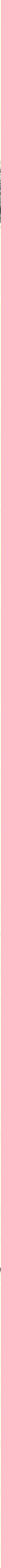


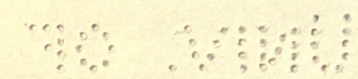

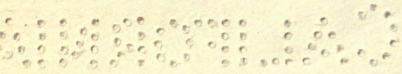



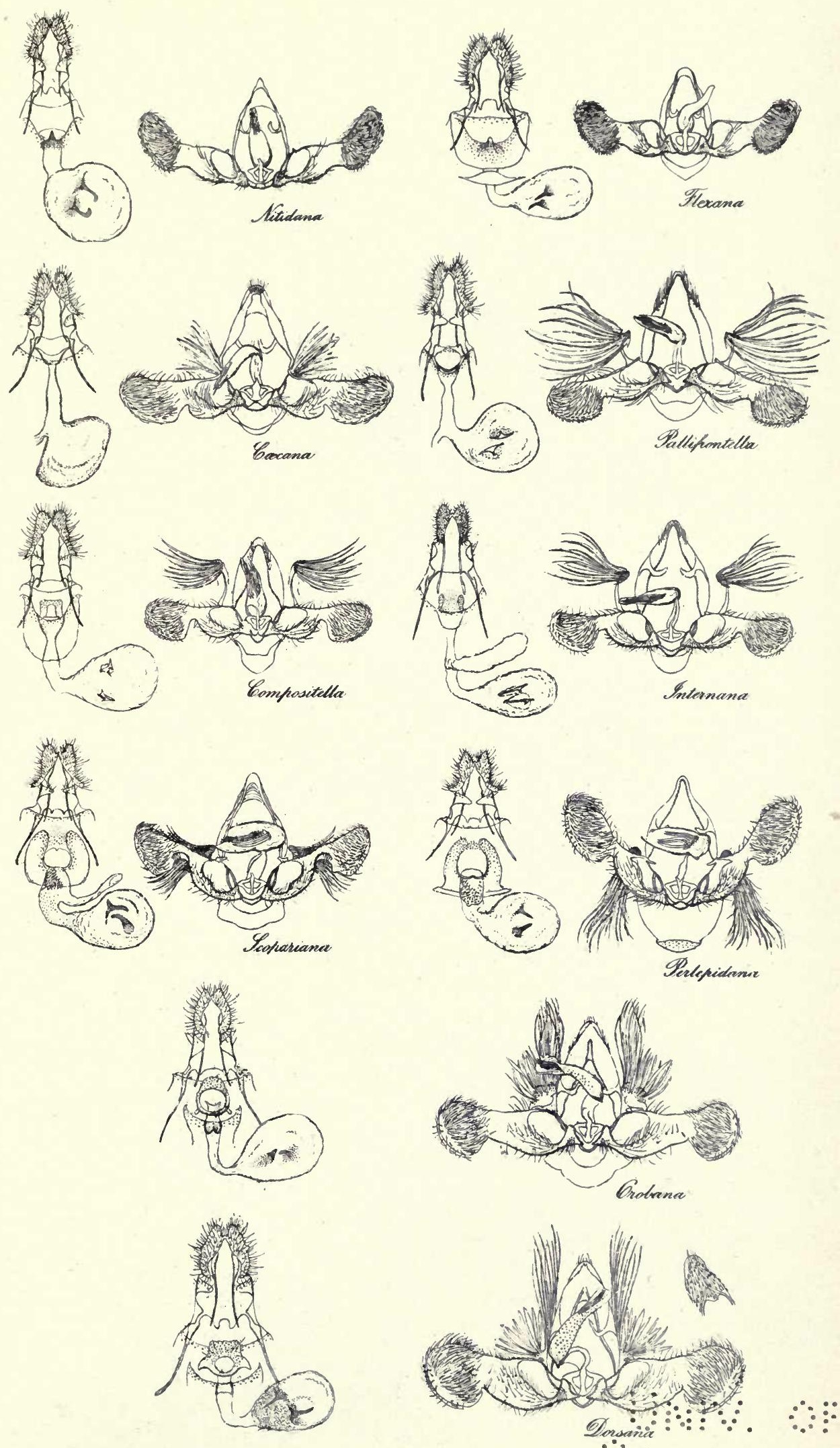


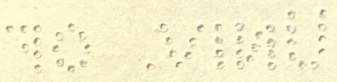

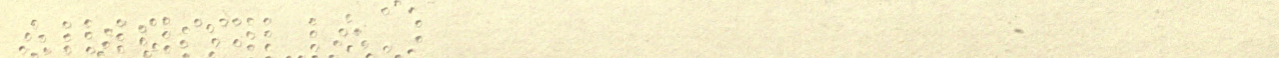



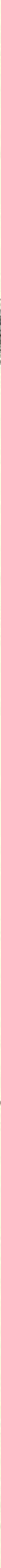


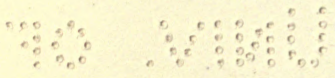

Sab 
Plate XXXI
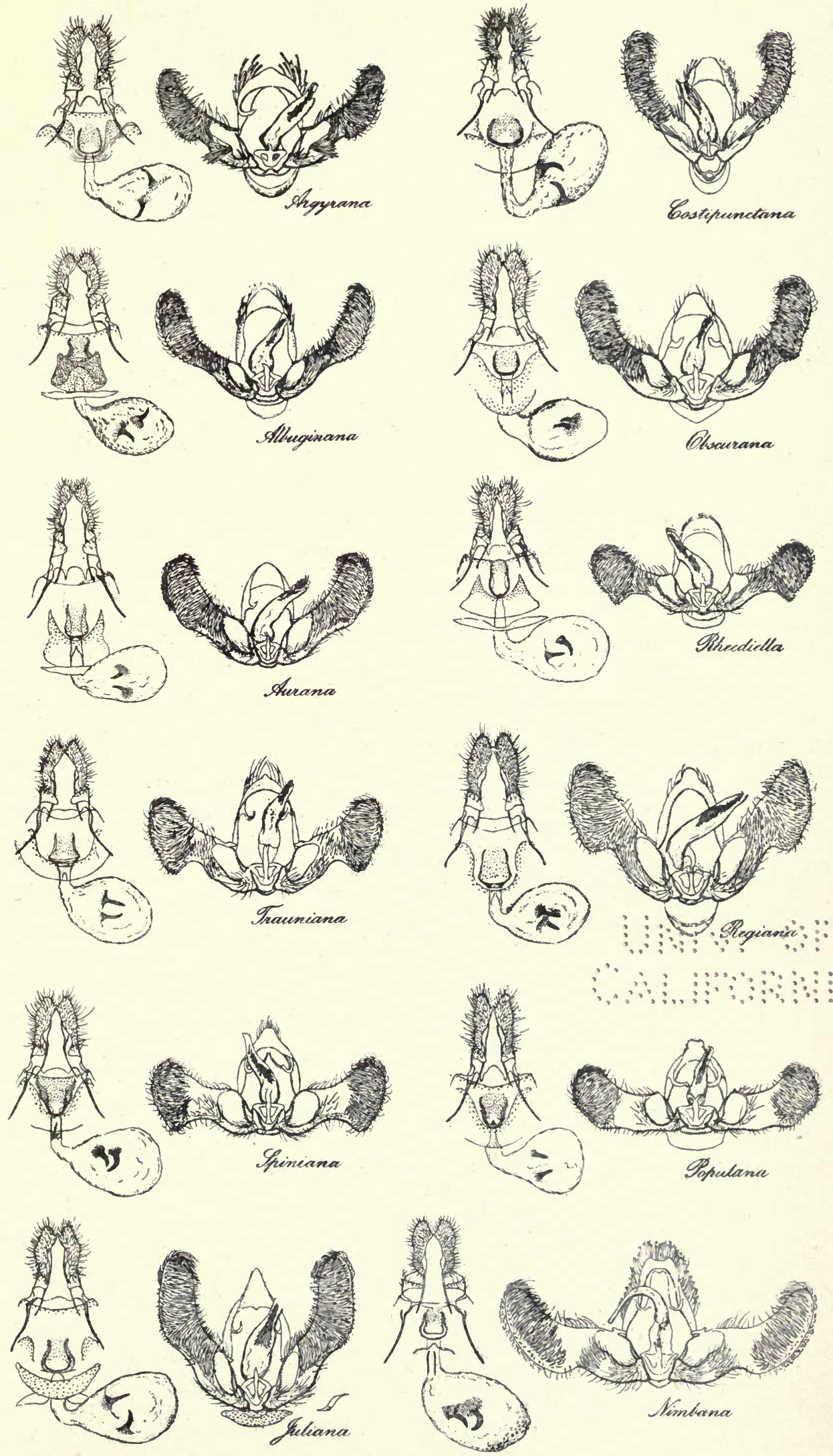
$\because \because \quad \because \because \because \vdots \vdots \vdots$

$\therefore \therefore: \therefore 0^{\circ} 0^{\circ} 00: \therefore \therefore 0^{\circ}$

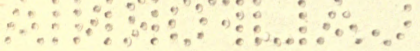


Plate XXXII
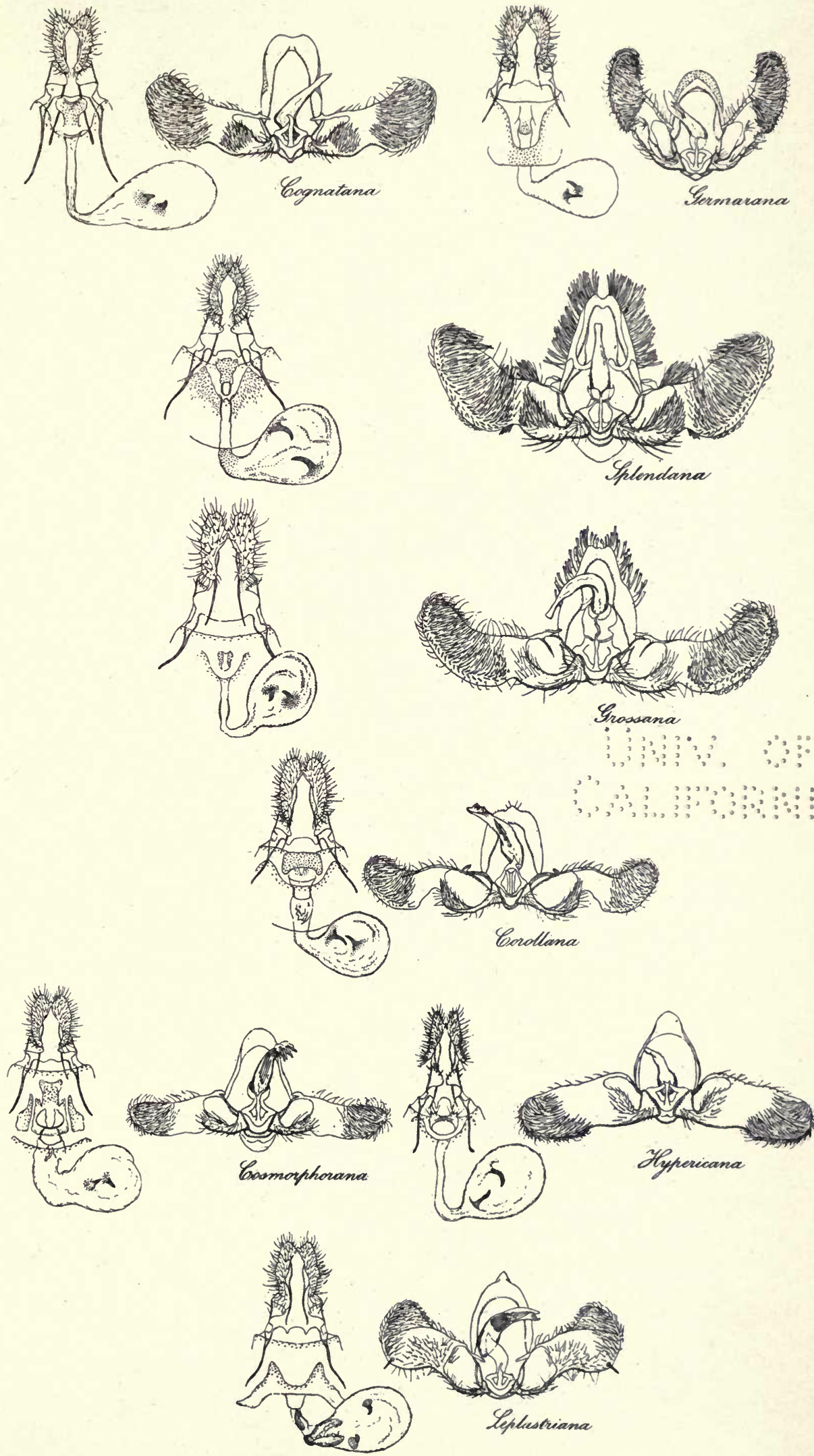


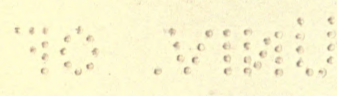

$\therefore$ 

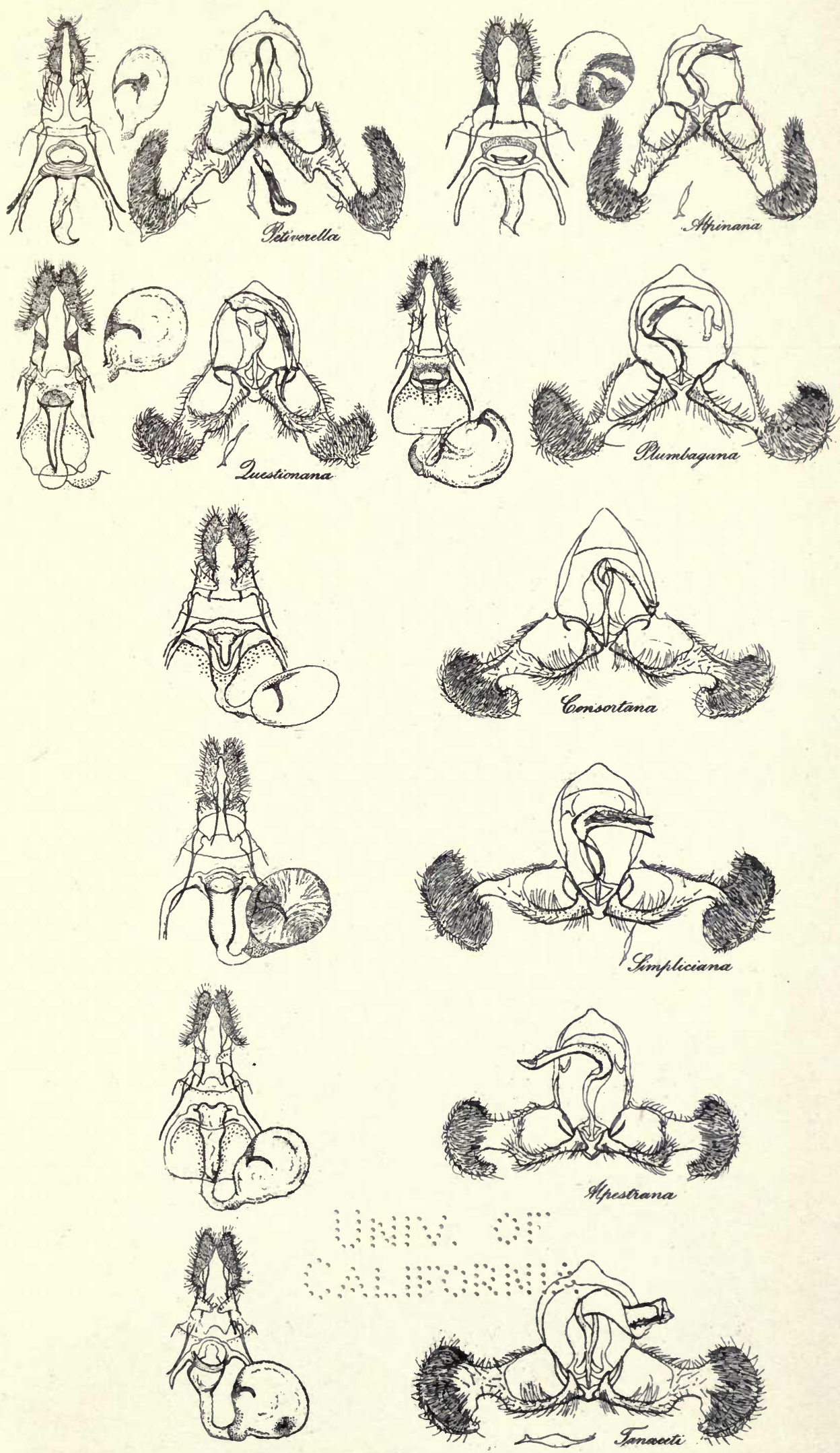
"

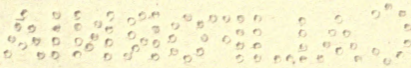


Plate XXXIV
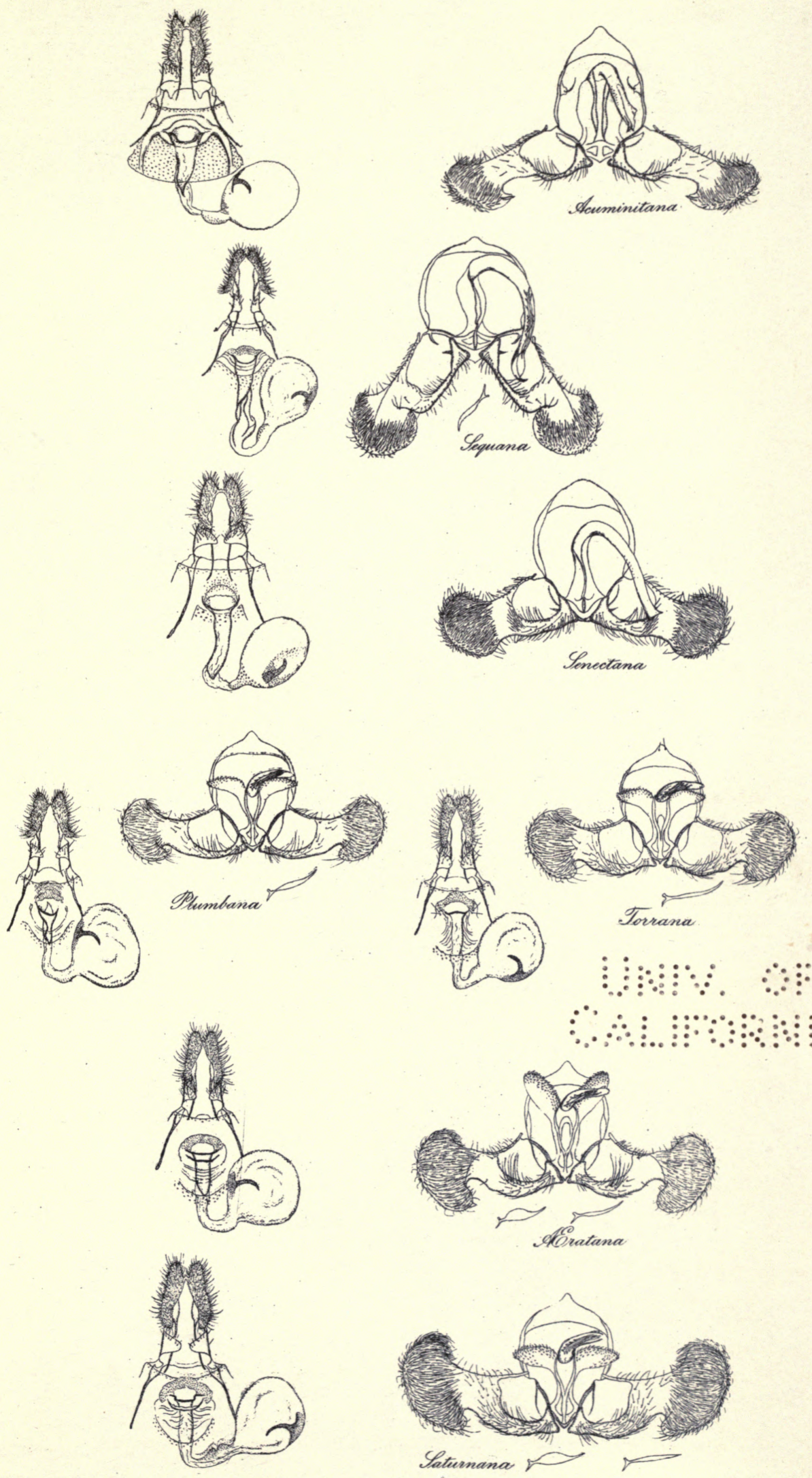

Saturnana $\square$ 
$\because y^{\prime}$

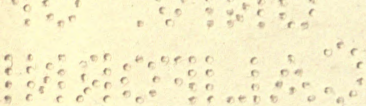



RETURN MARIAN KOSHLAND BIOSCIENCE AND TO $\rightarrow \quad$ NATURAL RESOURCES LIBRARY 2101 Valley Life Sciences Bldg. 642-2531

\section{LOAN PERIOD ONE MONTH LOAN}

ALL BOOKS MAY BE RECALLED AFTER 7 DAYS.

DUE AS STAMPED BELOW.
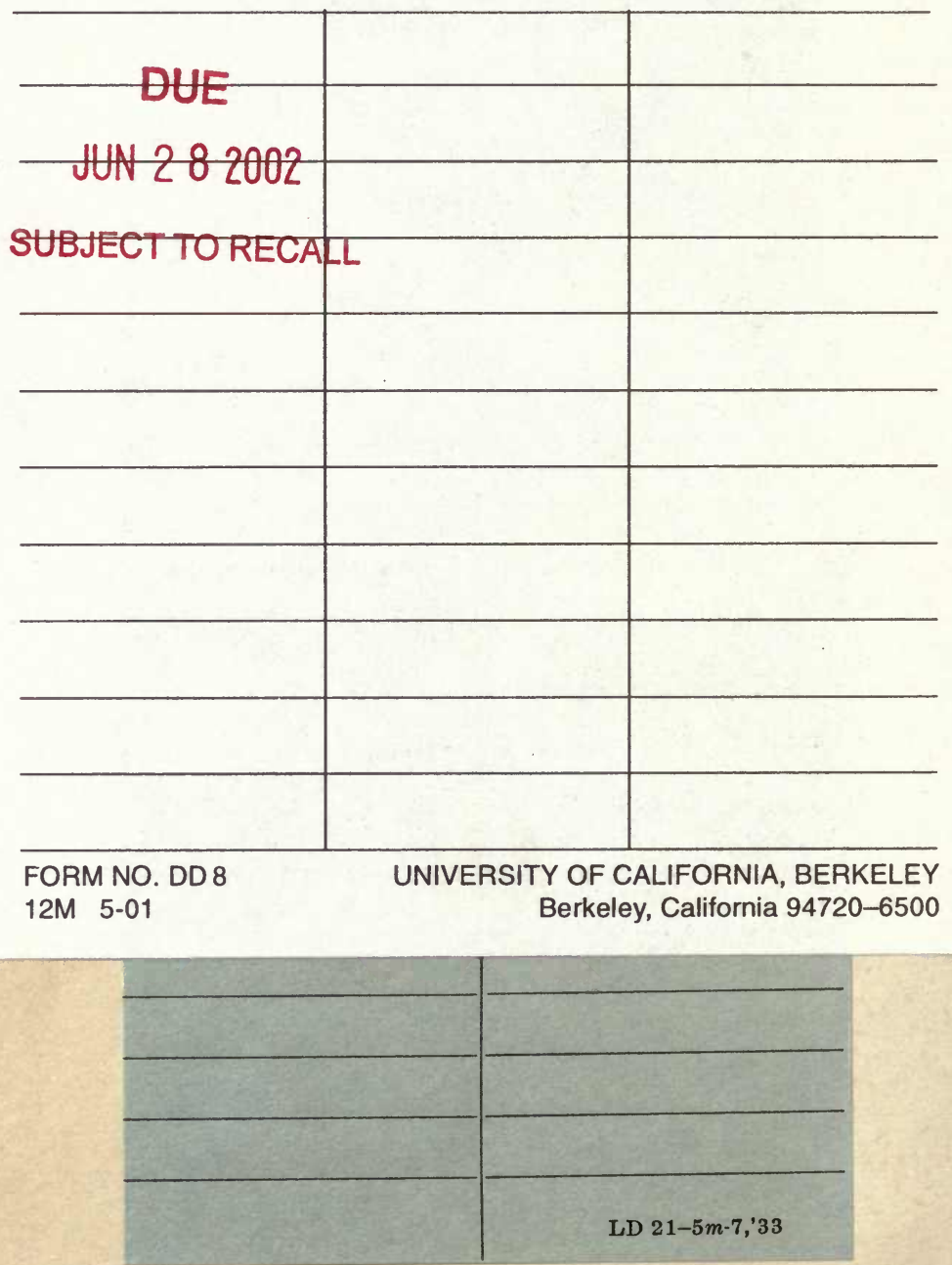


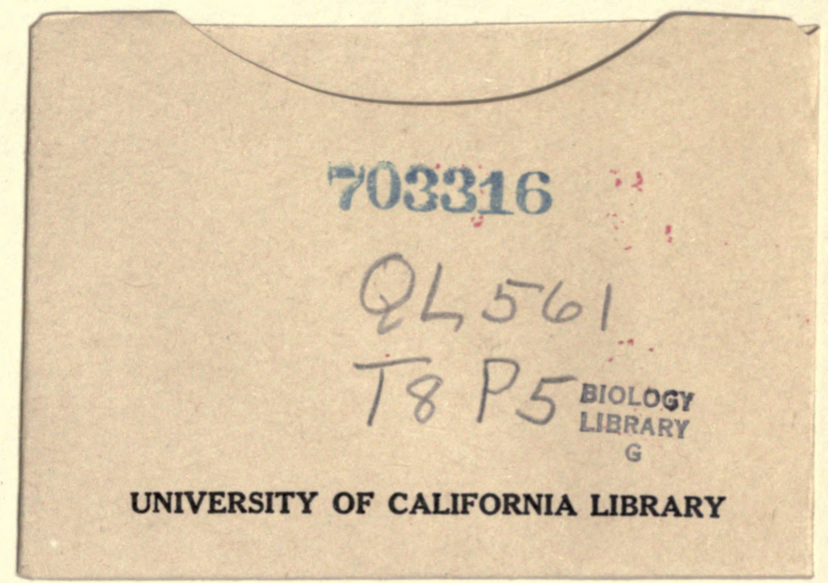


